This document was prepared in conjunction with work accomplished under Contract No. DE-AC09-96SR18500 with the U. S. Department of Energy.

\title{
DISCLAIMER
}

This report was prepared as an account of work sponsored by an agency of the United States Government. Neither the United States Government nor any agency thereof, nor any of their employees, nor any of their contractors, subcontractors or their employees, makes any warranty, express or implied, or assumes any legal liability or responsibility for the accuracy, completeness, or any third party's use or the results of such use of any information, apparatus, product, or process disclosed, or represents that its use would not infringe privately owned rights. Reference herein to any specific commercial product, process, or service by trade name, trademark, manufacturer, or otherwise, does not necessarily constitute or imply its endorsement, recommendation, or favoring by the United States Government or any agency thereof or its contractors or subcontractors. The views and opinions of authors expressed herein do not necessarily state or reflect those of the United States Government or any agency thereof. 


\section{DETERMINATION OF REPORTABLE RADIONUCLIDES FOR DWPF SLUDGE BATCH 3 (MACROBATCH 4)}

C. J. Bannochie

N. E. Bibler

May 2005

Immobilization Technology Section Savannah River National Laboratory Aiken, SC 29808

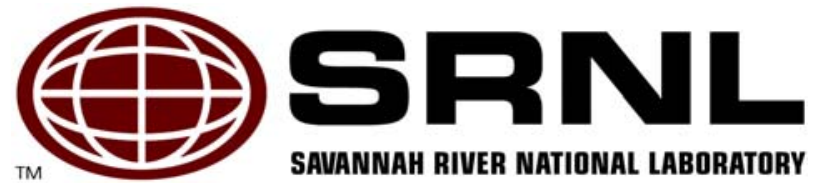




\title{
DISCLAIMER
}

This report was prepared by Westinghouse Savannah River Company (WSRC) for the United States Department of Energy under Contract No. DE-AC09-96SR18500 and is an account of work performed under that contract. Neither the United States Department of Energy, nor WSRC, nor any of their employees makes any warranty, expressed or implied, or assumes any legal liability or responsibility for the accuracy, completeness, or usefulness, of any information, apparatus, or product or process disclosed herein or represents that its use will not infringe privately owned rights. Reference herein to any specific commercial product, process, or service by trademark, name, manufacturer or otherwise does not necessarily constitute or imply endorsement, recommendation, or favoring of same by WSRC or by the United States Government or any agency thereof. The views and opinions of the authors expressed herein do not necessarily state or reflect those of the United States Government or any agency thereof.

\author{
Printed in the United States of America \\ Prepared For \\ U.S. Department of Energy
}


Key Words: DWPF, Sludge Batch 3, WAPS, Radionuclides

Retention: PERMANENT

\section{DETERMINATION OF REPORTABLE RADIONUCLIDES FOR DWPF SLUDGE BATCH 3 (MACROBATCH 4)}

C. J. Bannochie

N. E. Bibler

May 2005

Immobilization Technology Section Savannah River National Laboratory Aiken, SC 29808

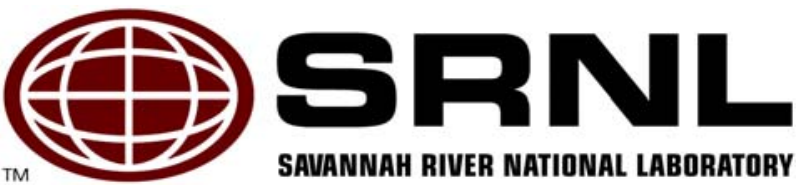


WSRC-TR-2005-00157

Revision 0

\section{REVIEWS AND APPROVALS}

\section{AUTHORS:}

C. J. Banmochie, Immobilization Technology Section

\section{TECHNICAL REVIEWERS:}

\begin{tabular}{lc} 
\\
R. A. Sigg, Anglytical Development Section & $6 / 13 / 05$ \\
\hline J. R. Harbour, Immobilization Technology Section & Date \\
& tune 13,2005
\end{tabular}

\section{APPROVERS}

\section{Ew toetzohute}

E. W. Holtzscheitor, Manager, Immobilization Technology Section

S. L. Marra, Manager, Glass Formulation \& Process Development

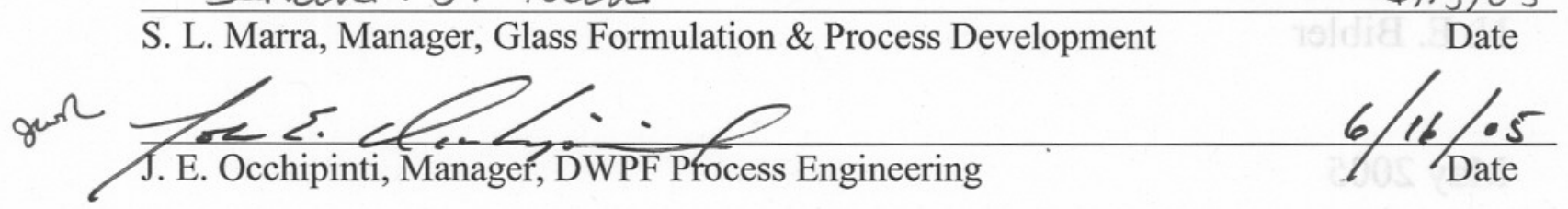




\section{EXECUTIVE SUMMARY}

The Waste Acceptance Product Specifications (WAPS) 11.2 require that "The Producer shall report the inventory of radionuclides (in Curies) that have half-lives longer than 10 years and that are, or will be, present in concentrations greater than 0.05 percent of the total inventory for each waste type indexed to the years 2015 and 3115”. As part of the strategy to meet WAPS 1.2, the Defense Waste Processing Facility (DWPF) will report for each waste type, all radionuclides (with half-lives greater than 10 years) that have concentrations greater than 0.01 percent of the total inventory from time of production through the 1100 year period from 2015 through 3115. The initial listing of radionuclides to be included is based on the design-basis glass as identified in the Waste Form Compliance Plan (WCP) ${ }^{2}$ and Waste Form Qualification Report (WQR) ${ }^{3}$. However, it is required that this list be expanded if other radionuclides with half-lives greater than 10 years are identified that meet the greater than $0.01 \%$ criterion for Curie content.

Specification 1.6 of the WAPS, IAEA Safeguards Reporting for HLW, requires that the ratio by weights of the following uranium and plutonium isotopes be reported: U-233, U-234, U-235, U-236, U-238, Pu-238, Pu-239, Pu-240, Pu-241, and Pu-242. Therefore, the complete set of reportable radionuclides must also include this set of $\mathrm{U}$ and $\mathrm{Pu}$ isotopes.

The Defense Waste Processing Facility (DWPF) is receiving radioactive sludge slurry from High Level Waste Tank 40. The radioactive sludge slurry in Tank 40 is a blend of the previous contents of Tank 40 (Sludge Batch 2) and the sludge that was transferred to Tank 40 from Tank 51. The blend of sludge from Tank 51 and Tank 40 defines Macrobatch 4 (also referred to as Sludge Batch 3). This report develops the list of reportable radionuclides and associated activities and determines the radionuclide activities as a function of time. The DWPF will use this list and the activities as one of the inputs for the development of the Production Records that relate to radionuclide inventory.

This work was initiated through Task Technical Request HLW/DWPF/TTR-03-0005, Revision 1 entitled Sludge Batch 3 SRTC Shielded Cells Testing ${ }^{4}$. Specifically, this report details results from performing, in part, Subtask 3 of the TTR and, in part, meets Deliverable 6 of the TTR. The work was performed following the Technical Task and Quality Assurance Plan (TTQAP), WSRC-RP2003-00249, Rev. $1^{5}$ and Analytical Study Plan (ASP), WSRC-RP-2004-00262 ${ }^{6}$.

In order to determine the reportable radionuclides for Sludge Batch 3 (Macro Batch 4), a list of radioisotopes that may meet the criteria as specified by the Department of Energy's (DOE) WAPS was developed. All radioactive U-235 fission products and all radioactive activation products that could be in the SRS HLW were considered. In addition, all U and Pu isotopes identified in WAPS 1.6 were included in the list. This list was then evaluated and some isotopes excluded from the projection calculations.

${ }^{1}$ Office of Environmental Management, Waste Acceptance Product Specifications for Vitrified High-Level Waste Forms, USDOE Document DOE/EM-0093, Rev. 2, December 1996.

${ }^{2}$ Westinghouse Savannah River Company, DWPF Waste Form Compliance Plan, WSRC-IM-91-116-0, Rev. 7, Savannah River Site, June 2003.

${ }^{3}$ Westinghouse Savannah River Company, DWPF Waste Form Qualification Report, Volume 4: Reporting the Radionuclides Inventory of the DWPF Product, WSRC-IM-91-116-4, Rev. 2, Savannah River Site, June 2003.

${ }^{4}$ Rios-Armstrong, M. A., Technical Task Request: Sludge Batch 3 SRTC Shielded Cells Testing, WLW/DWPF/TTR-030005, Revision 1, Savannah River Site, June 2003.

${ }^{5}$ Pareizs, J. M., Task Technical and Quality Assurance Plan: Washing and Qualification of Sludge Batch 3 Radioactive Sludge Slurry, WSRC-RP-2003-00249, Revision 1, Savannah River Site, June 2003.

${ }^{6}$ Pareizs, J. M., Analytical Study Plan: Characterization of the Tank 40 Sludge Batch 3 Sample, WSRC-RP-2004-000262, Revision 0, Savannah River Site, March 2004. 
Based on measurements and analytical detection limits, thirty radionuclides have been identified as reportable for DWPF SB3 (MB4) as specified by WAPS 1.2. The 30 reportable nuclides are:

\begin{tabular}{cccccc}
\hline Ni-59 & Ni-63 & Se-79 & Sr-90 & Zr-93 & Nb-93m \\
Tc-99 & Sn-121m & Sn-126 & Cs-137 & Sm-151 & U-233 \\
U-234 & Np-237 & U-238 & Pu-238 & Pu-239 & Pu-240 \\
Am-241 & Am-242m & Pu-241 & Pu-242 & Am-243 & Cm-244 \\
Cm-245 & Cm-246 & Cm-247 & Cm-248 & Cf-249 & Cf-251 \\
\hline
\end{tabular}

The WCP and WQR require that all of radionuclides present in the Design Basis glass be considered as the initial set of reportable radionuclides. For SB3 (MB4) all of the radionuclides in the Design Basis glass are reportable except for three radionuclides: Pd-107, Cs-135, and Th-230. At no time through the calendar year 3115 did any of these three radionuclides contribute to more than $0.01 \%$ of the radioactivity on a Curie basis.

Two additional uranium isotopes (U-235 and -236) must be added to the list of reportable radionuclides in order to meet WAPS 1.6. All of the Pu isotopes and other U isotopes (U-233, -234, and -238) identified in WAPS 1.6 were already determined to be reportable according to WAPS 1.2 This brings the total number of reportable radionuclides for SB3 to thirty-two.

Earlier WAPS radionuclide inventory work had additional analytical work performed. Some of these extra steps were eliminated during this WAPS inventory analysis with the belief that there would be no significant impact. For example, for SB2, the Am/Cm method was performed in the SRNL Shielded Cells with a larger portion of dissolved sludge solids, thereby producing a larger portion of the eluent with reduced activity which could be removed from the Cells. This larger eluent can be more accurately counted for Cm-247, Cf-249, and Cf-251. This in turn would improve the estimation of Cm-248. Additionally, this more concentrated eluent can be analyzed by ICP-MS, thus improving the measurement of Cm-245 and Cm-246. In hindsight, eliminating this Shielded Cells work resulted in some final radionuclide concentrations based upon detection limits rather than measured values. This in turn may have made some radionuclides reportable when they would have been non-reportable had the earlier methodology been repeated and more precise measurements obtained. In the future, it is recommended that this issue be examined further to determine if reducing the number of reportable radionuclides to the greatest extent possible is important. 


\section{TABLE OF CONTENTS}

EXECUTIVE SUMMARY iii

LIST OF TABLES vii

LIST OF ACRONYMS AND ABBREVIATIONS viii

1.0 INTRODUCTION 1

1.1 Background 1

1.2 Radionuclides Identified For Consideration as Reportable 1

2.0 EXPERIMENTAL 3

2.1 Direct Methods 3

2.1.1 ICP-MS 3

2.1.2 Gamma Counting 3

2.1.3 Liquid Scintillation Counting 3

2.2 Separation Methods 3

2.2.1 Ni-59/-63 Method 4

2.2.2 Se-79 Method 4

2.2.3 Sr-90 Method 4

2.2.4 Gamma Counting Following Cs-137 Removal 4

2.2.5 I-129 Method 5

2.2.6 Pu-238/-241 Method 5

2.2.7 Am/Cm Method 5

2.3 Calculated Activities of the Remaining Radionuclides 6

2.3.1 Pd-107

2.3.2 Cs-135

2.3.3 Pm-147

2.3.4 Cm-245 and $\mathrm{Cm}-246 \quad 7$

$\begin{array}{ll}2.3 .5 \mathrm{Cm}-248 & 7\end{array}$

3.0 RESULTS AND DISCUSSION 9

3.1 Summary of the Activities and Radionuclides for Input 9

3.2 Identification of Reportable Radionuclides 11

3.3 The Ratio by Weight of U and Pu Isotopes 13

$\begin{array}{ll}\text { 4.0 CONCLUSIONS } & 15\end{array}$

5.0 RECOMMENDATIONS 17

6.0 REFERENCES 19

7.0 ACKNOWLEDGEMENTS 21

APPENDIX A. Activities of Dried Sludge in Year $2015(\mu \mathrm{Ci} / \mathrm{g}) \quad 23$

APPENDIX B. Activities of Dried Sludge in Year $2115(\mu \mathrm{Ci} / \mathrm{g}) \quad 25$

APPENDIX C. Activities of Dried Sludge in Year $2215(\mu \mathrm{Ci} / \mathrm{g}) \quad 27$

APPENDIX D. Activities of Dried Sludge in Year $2315(\mu \mathrm{Ci} / \mathrm{g})$

APPENDIX E. Activities of Dried Sludge in Year $2415(\mu \mathrm{Ci} / \mathrm{g}) \quad 31$

APPENDIX F. Activities of Dried Sludge in Year $2515(\mu \mathrm{Ci} / \mathrm{g})$

APPENDIX G. Activities of Dried Sludge in Year $2615(\mu \mathrm{Ci} / \mathrm{g})$

APPENDIX H. Activities of Dried Sludge in Year $2715(\mu \mathrm{Ci} / \mathrm{g})$

APPENDIX I. Activities of Dried Sludge in Year $2815(\mu \mathrm{Ci} / \mathrm{g})$

APPENDIX J. Activities of Dried Sludge in Year $2915(\mu \mathrm{Ci} / \mathrm{g})$ 
WSRC-TR-2005-00157

Revision 0

APPENDIX K. Activities of Dried Sludge in Year $3015(\mu \mathrm{Ci} / \mathrm{g})$

43

APPENDIX L. Activities of Dried Sludge in Year $3115(\mu \mathrm{Ci} / \mathrm{g})$

45 


\section{LIST OF TABLES}

Table 1-1. List of Radioisotopes Considered for Sludge Batch 3 (Macrobatch 4).................. 2

Table 1-2. Radioisotopes Excluded for Determination of Reportable Radioisotopes for

Sludge Batch 3 (Macrobatch 4) 2

Table 3-1. List of Radionuclides and Activities Used as Input to the RadDecay ${ }^{\circledR}$ Program. 10

Table 3-2. Reportable Radionuclides in DWPF Sludge Batch 3 (Macrobatch 4) ................ 12

Table 3-3. Reportable Radionuclides in DWPF Sludge Batch 1B (Macrobatch 2) ${ }^{16} \ldots \ldots . . . . .12$

Table 3-4. Reportable Radionuclides in DWPF Sludge Batch 2 (Macrobatch 3) ${ }^{17}$.............. 12

Table 3-5. Uranium Isotope Distribution in DWPF Sludge Batch 3 (Macrobatch 4) ........... 13

Table 3-6. Plutonium Isotope Distribution in DWPF Sludge Batch 3 (Macrobatch 4)......... 13 


\section{LIST OF ACRONYMS AND ABBREVIATIONS}

\begin{tabular}{|c|c|}
\hline ADS & Analytical Development Section \\
\hline ASP & Analytical Study Plan \\
\hline DOE & Department of Energy \\
\hline dpm & disintegrations per minute \\
\hline DWPF & Defense Waste Processing Facility \\
\hline g & gram \\
\hline HLW & High Level Waste \\
\hline ICP-AES & Inductively Coupled Plasma - Atomic Emission Spectroscopy \\
\hline ICP-MS & Inductively Coupled Plasma - Mass Spectrometry \\
\hline MB2 & Macrobatch 2 \\
\hline MB3 & Macrobatch 3 \\
\hline MB4 & Macrobatch 4 \\
\hline$\mu \mathrm{Ci}$ & micro-Curies \\
\hline PHA & Pulse Height Analysis \\
\hline QA & Quality Assurance \\
\hline SB1B & Sludge Batch 1B \\
\hline SB2 & Sludge Batch 2 \\
\hline SB3 & Sludge Batch 3 \\
\hline SCO & SRNL Shielded Cells Operations \\
\hline SpA & Specific Activity (Ci/g) \\
\hline SRNL & Savannah River National Laboratory \\
\hline SRS & Savannah River Site \\
\hline SRTC & Savannah River Technology Center \\
\hline$t_{1 / 2}$ & half-life \\
\hline TTQAP & Task Technical and Quality Assurance Plan \\
\hline TTR & Task Technical Request \\
\hline WAPS & Waste Acceptance Product Specifications \\
\hline WCP & Waste Form Compliance Plan \\
\hline WQR & Waste Form Qualification Report \\
\hline
\end{tabular}




\subsection{INTRODUCTION}

\subsection{Background}

The Waste Acceptance Product Specifications (WAPS) 1.2 require that "The Producer shall report the inventory of radionuclides (in Curies) that have half-lives longer than 10 years and that are, or will be, present in concentrations greater than 0.05 percent of the total inventory for each waste type indexed to the years 2015 and 3115”. As part of the strategy to meet WAPS 1.2, the Defense Waste Processing Facility (DWPF) will report for each waste type, all radionuclides (with half-lives greater than 10 years) that have concentrations greater than 0.01 percent of the total inventory from time of production through the 1100 year period from 2015 through 3115. The initial listing of radionuclides to be included is based on the design-basis glass as identified in the Waste Form Compliance Plan (WCP) ${ }^{2}$ and Waste Form Qualification Report (WQR) ${ }^{3}$. However, it is required that this list be expanded if other radionuclides with half-lives greater than 10 years are identified that meet the greater than $0.01 \%$ criterion for Curie content.

Specification 1.6 of the WAPS, IAEA Safeguards Reporting for HLW, requires that the ratio by weights of the following uranium and plutonium isotopes be reported: U-233, U-234, U-235, U-236, U-238, Pu238, Pu-239, Pu-240, Pu-241, and Pu-242. Therefore, the complete set of reportable radionuclides must also include this set of $\mathrm{U}$ and $\mathrm{Pu}$ isotopes.

The Defense Waste Processing Facility (DWPF) is receiving radioactive sludge slurry from High Level Waste Tank 40. The radioactive sludge slurry in Tank 40 is a blend of the contents of Tank 40 and the sludge that was transferred to Tank 40 from Tank 51. The blend of sludge from Tank 51 and Tank 40 defines Macrobatch 4 (also referred to as Sludge Batch 3). This report develops the list of reportable radionuclides and associated activities and determines the radionuclide activities as a function of time. The DWPF will use this list and the activities as one of the inputs for the development of the Production Records that relate to radionuclide inventory.

This work was initiated through Task Technical Request HLW/DWPF/TTR-03-0005, Revision 1 entitled Sludge Batch 3 SRTC Shielded Cells Testing ${ }^{4}$. Specifically, this report details results from performing, in part, Subtask 3 of the TTR and, in part, meets Deliverable 6 of the TTR. The work was performed following the Technical Task and Quality Assurance Plan (TTQAP), WSRC-RP-2003-00249, Rev. $1^{5}$ and Analytical Study Plan (ASP), WSRC-RP-2004-00262 ${ }^{6}$.

\subsection{Radionuclides Identified For Consideration as Reportable}

In order to determine the reportable radionuclides for Sludge Batch 3 (Macrobatch 4), a list of radioisotopes that may meet the criteria as specified by the Department of Energy's (DOE) WAPS was developed. All radioactive U-235 fission products and all radioactive activation products that could be in the SRS HLW were considered. In addition, all U and Pu isotopes identified in WAPS 1.6 have been included in this list.

Table 1-1 presents the list of radioisotopes identified for consideration as reportable. The radioisotopes that were deleted from the list and the arguments that support that decision are presented in Table 1-2. 
WSRC-TR-2005-00157

Revision 0

Table 1-1. List of Radioisotopes Considered for Sludge Batch 3 (Macrobatch 4)

\begin{tabular}{|c|c|c|c|}
\hline Radioisotope & Radioisotope & Radioisotope & Radioisotope \\
\hline $\mathrm{C}-14^{\mathrm{a}}$ & Sn-126 ${ }^{b}$ & Ac- $227^{d}$ & $\mathrm{Pu}-241^{\mathrm{a}}$ \\
\hline $\mathrm{Ni}-59^{\mathrm{a}}$ & $\mathrm{I}-129^{\mathrm{b}}$ & Th-229 ${ }^{d}$ & $\mathrm{Pu}-242^{\mathrm{a}}$ \\
\hline Co- $60^{a}$ & Cs- $135^{b}$ & Th-230 d & Am-241 \\
\hline $\mathrm{Ni}-63^{\mathrm{a}}$ & $\mathrm{Cs}-137^{\mathrm{b}}$ & $\mathrm{Pa}-231^{\mathrm{d}}$ & $A m-242 m^{a}$ \\
\hline Se-79 ${ }^{b}$ & La-138 ${ }^{b}$ & Th-232 ${ }^{\mathrm{c}}$ & $\mathrm{Am}-243^{\mathrm{a}}$ \\
\hline $\mathrm{Rb}-87^{\mathrm{b}}$ & Ce-142 b, c & $\mathrm{U}-232^{\mathrm{a}}$ & $\mathrm{Cm}-243^{\mathrm{a}}$ \\
\hline Sr-90 ${ }^{b}$ & $\mathrm{Nd}-144^{\mathrm{b}}$ & $\mathrm{U}-233^{\mathrm{a}}$ & $\mathrm{Cm}-244^{\mathrm{a}}$ \\
\hline Zr-93 ${ }^{b}$ & Sm-147 ${ }^{b}$ & $\mathrm{U}-234^{\mathrm{d}}$ & $\mathrm{Cm}-245^{\mathrm{a}}$ \\
\hline $\mathrm{Nb}-93 \mathrm{~m}^{\mathrm{b}}$ & Sm-149 & $\mathrm{U}-235^{\mathrm{c}}$ & $\mathrm{Cm}-246^{\mathrm{a}}$ \\
\hline $\mathrm{Nb}-94^{\mathrm{a}}$ & $\mathrm{Nd}-150^{\mathrm{b}}$ & $\mathrm{U}-236^{\mathrm{a}}$ & $\mathrm{Cm}-247^{\mathrm{a}}$ \\
\hline $\mathrm{Zr}-96^{\mathrm{b}}$ & Sm-151 b & $N p-236^{a}$ & $\mathrm{Cm}-248^{\mathrm{a}}$ \\
\hline Tc- $99^{\mathrm{b}}$ & Eu-152 b & $\mathrm{Np}-237^{\mathrm{a}}$ & Cf-249 ${ }^{a}$ \\
\hline $\mathrm{Cd}-113^{\mathrm{b}, \mathrm{c}}$ & Eu-154 b & $\mathrm{U}-238^{\mathrm{c}}$ & Cf- $250^{a}$ \\
\hline Pd-107 ${ }^{b}$ & $\mathrm{Bi}-210 \mathrm{~m}^{\mathrm{d}}$ & $\mathrm{Pu}-238^{\mathrm{a}}$ & Cf-251 ${ }^{a}$ \\
\hline In-115 b & $\mathrm{Pb}-210^{\mathrm{d}}$ & $\mathrm{Pu}-239^{\mathrm{a}}$ & \\
\hline Sn- $121 m^{b}$ & $\mathrm{Ra}-226^{\mathrm{d}}$ & $\mathrm{Pu}-240^{\mathrm{a}}$ & \\
\hline
\end{tabular}

${ }^{\mathrm{a}}$ Activation product

${ }^{\mathrm{b}}$ Fission product

${ }^{\mathrm{c}}$ Naturally occurring radionuclide that resulted in the waste from processing at SRS

${ }^{\mathrm{d}}$ Decay product of an actinide isotope in SRS waste

Table 1-2. Radioisotopes Excluded for Determination of Reportable Radioisotopes for Sludge Batch 3 (Macrobatch 4)

\begin{tabular}{|c|c|}
\hline Radioisotope & Radioisotope \\
\hline $\mathrm{C}-14^{\mathrm{i}}$ & Nd-144 ${ }^{\text {iii }}$ \\
\hline $\mathrm{Nb}-94^{\mathrm{ii}}$ & Nd-150 iii \\
\hline Zr-96 ${ }^{\mathrm{iii}}$ & Sm-147 \\
\hline Cd-113 iii & Sm-149 \\
\hline In- $115^{\text {iii }}$ & Eu-152 $2^{\mathrm{ii}}$ \\
\hline La-138 iii & $\mathrm{Np}-236^{\mathrm{iv}}$ \\
\hline Ce-142 ${ }^{\text {iii }}$ & $\mathrm{U}-232^{\mathrm{v}}$ \\
\hline
\end{tabular}

i. $\mathrm{C}-14$ is volatilized during DWPF Chemical and Melt Cell processing and is not immobilized in the glass ${ }^{7}$.

ii. "Nb-94 and Eu-152 are shielded isotopes: the isobaric fission product decay chain for these stops at a stable isotope before reaching these. They are therefore produced predominately by secondary processes, and are present only in very small amounts. They have not been observed in the sludge slurry"

iii. Zr-96, Cd-113, In-115, La-138, Ce-142, Nd-144, Nd-150, Sm-147 and Sm-149 were deleted because their long half -lives (> 1.05E11 years) make their activities negligible at all times ${ }^{8}$.

iv. “No data was available for Np-236 but it is known to be made in only very small amounts in reactor irradiation. Np-236 is a minor product of fast neutron spallation. It was neglected”8.

v. "U-232 is present only in very small amounts and decays rapidly compared to other actinide isotopes that are much more abundant (it is primarily obtained as a contaminant at a few ppm from the reactor irradiation of Th-232)" ${ }^{8}$. 


\subsection{EXPERIMENTAL}

The details for sample acquisition from Tank 40, preparation of the digestions, and measurement of the elemental composition have been published separately ${ }^{9}$. The results for those radionuclides that required additional separation techniques that were not included in the referenced report have been included in this report. Details of the separation and detection methods are provided. All measurements and counting analyses were done by the SRNL Analytical Development Section (ADS).

\subsection{Direct Methods}

\subsubsection{ICP-MS}

Inductively coupled plasma - mass spectrometry (ICP-MS) was employed to analyze separate subsamples of the aqua regia digestions of Tank 40 dried solids described in a previous report ${ }^{9}$. Measurements were first converted to weight percents on a dried solids basis and then converted to activities using the specific activity of each isotope taken from References 10 and 13 . The isotopes obtained from direct ICP-MS measurements included: Zr-93, Tc-99, Sm-151, Th-232, U-233, U-234, U235, U-236, Np-237, U-238, Pu-239, Pu-240, and Pu-242.

\subsubsection{Gamma Counting}

Gamma Pulse Height Analysis (PHA) was performed on separate sub-samples of the peroxide fusion digestions of Tank 40 dried solids described in a previous report ${ }^{9}$. Detectors were carefully calibrated with known standards. Since detection efficiencies for gamma-rays vary with energy, they were determined for these specific radionuclide energies during the calibration process. The counting geometry was established during calibration and carefully duplicated for these measurements. Samples were diluted as necessary to achieve accurate counting. The isotopes obtained from Gamma PHA counting included: Co-60, Cs-134, Cs-137, Eu-154, Eu-155, and Am-241.

\subsubsection{Liquid Scintillation Counting}

Liquid scintillation counting was performed on separate sub-samples of the peroxide fusion digestions of Tank 40 dried solids described in a previous report ${ }^{9}$. The scintillation cocktail used for the analysis was Ultima Gold AB since it is specifically formulated for alpha-beta discrimination and is the best choice for samples dissolved in mineral acids. Measurements were performed on one of three Packard Instruments which automatically correct for quenching and many other interference problems commonly associated with liquid scintillation counting. This method was used to determine total Beta activity. The calculated disintegrations per minute ( $\mathrm{dpm})$ values are based upon an average beta-particle detection efficiency of $70 \%$ for Beta activity falling outside the Tritium energy window. Beta activity falling inside the Tritium energy window is corrected with an efficiency based on the Tritium quench curve. The total Beta activity reported by ADS is a sum of these two figures. Samples were counted for ten minutes.

\subsection{Separation Methods}

These analytical methods involved separation techniques that enabled radionuclides that were at low concentrations to be measured more accurately and to determine more reliable and lower detection limits for the radionuclides that had concentrations so low that they could not be detected. These techniques are now SRNL ADS procedures and will only be summarized here. Aliquots of the peroxide fusions of the Aqua Regis dissolutions were analyzed along with blanks. In all cases the activity in the blanks did not contribute any significant activity to the radionuclides being analyzed. 


\subsubsection{Ni-59/-63 Method}

This separation is based on isolation of $\mathrm{Ni}$ from the dissolved sludge using a column containing dimethylglyoxime as an extractant that is specific for $\mathrm{Ni}$. Each of the solutions resulting from the sodium peroxide dissolutions of the four samples of dried sludge slurry was passed through a column containing the above extractant. The absorbed Ni was then eluted from each column. The Ni-59 was measured in the eluted solutions by its characteristic X-rays and Ni-63 by its beta particles. Total Ni in each eluted solution was measured by inductively coupled plasma atomic emission spectroscopy (ICPAES). To determine the fraction of $\mathrm{Ni}$ removed by the column the total $\mathrm{Ni}$ in each eluted solution was compared to the total Ni measured by ICP-MS in that respective dissolved dried slurry. The average result for the total Ni concentration has been published previously ${ }^{9}$.

\subsubsection{Se-79 Method}

An aliquot from each of the four samples from the sealed Aqua Regia dissolutions ${ }^{9}$ was spiked with a known amount of stable Se as a carrier. The total Se was reduced to Se metal using titanium (III) chloride, hydroxylamine hydrochloride, and ascorbic acid. The precipitated Se metal was then washed repeatedly with deionized water and dilute nitric acid. The Se metal was then dissolved with concentrated $\mathrm{HBr}$, and the resulting $\mathrm{SeBr}_{4}$ was extracted using a commercial resin. The Se was eluted from the resin, oxidized with nitric acid, and further purified with several batch additions of an anion resin, and a resin to remove Cs-137. Aliquots of the purified Se fraction were then analyzed. A portion was neutron activated in a Cf-252 neutron source at SRNL to determine the total amount of Se present in order to calculate the recovery of Se in the analytical techniques. A second portion was counted by liquid scintillation to determine the Se-79 beta activity. The yields of the stable Se carrier were applied to the Se-79 beta activity result to determine Se-79 activities in the sample aliquots initially treated. Even though recoveries were good, Se-79 was not detected in any of the dissolved samples. An upper limit of the Se-79 concentration was then determined and used to calculate the maximum activity for Se79 as input for the projection calculations.

\subsubsection{Sr-90 Method}

Aliquots of each sample from the sodium peroxide dissolutions ${ }^{9}$ were spiked with a stable Sr carrier, and a stable Ce carrier. The Sr carrier was used for separation yielding purposes and the Ce carrier was used to enhance the separation rates of undesirable isotopes such as Y-90, the lanthanides or the actinides. The spiked sample aliquots were initially oxidized using nitric acid. The $\mathrm{Sr}$ in the samples was extracted using commercially available $\mathrm{Sr}$ extraction resin. This resin also extracts some of the $\mathrm{Pu}$ under the conditions used to extract the Sr. The Pu was washed from the resin using an oxalic acid/nitric acid mixture. The Sr was eluted from the resin, and the resulting solution concentrated. A portion of the purified Sr solution was neutron activated in a Cf-252 neutron activation facility at SRNL to determine the total $\mathrm{Sr}$ and in order to calculate the fraction of $\mathrm{Sr}$ isolated by the procedure. A second portion of each of the Sr fractions was stored for five to seven days to allow Y-90 to grow in. Each fraction was then counted by liquid scintillation analysis to determine the Y-90 activity. The Sr-90 beta activity in each case was calculated from the Y-90 activity. The yields of the stable Sr carriers were applied to the Sr-90 beta activity results to determine Sr-90 activities in the original aliquots of the solutions resulting from the dissolution of the dried sludge slurry samples.

\subsubsection{Gamma Counting Following Cs-137 Removal}

This method was used to determine Ru-106, Sb-125, Ce-144, Sn-121m, and Sn-126. These gamma emitters could not be determined directly because of the high Cs-137 activity in the samples. Consequently the Cs-137 was removed. Aliquots of each of the four sodium peroxide dissolutions ${ }^{9}$ of the dried sludge slurry samples were treated with two batch additions of an ammonium phosphomolybdate resin to selectively remove the Cs-137 from the aliquots. This allowed gammas for isotopes at low concentrations to be detected or allowed lower detection limits to be determined for those isotopes that were not detected. The Cs-137 decontaminated aliquots were then gamma counted in two 
different detectors. The first was a high purity coaxial germanium detector to detect the gamma rays from Ru-106, Sb-125, Ce-144, and Sn-126. Only Sb-125 was detected. Because of their low concentrations the other isotopes were not detected. To obtain reliable and lower detection limits for these radionuclides, each of the solutions was counted for 27.8 hours. The detection limits were used to calculate the maximum activity of each for input to the projection calculations. Of this group of radionuclides, only Sn-126 has a half-life greater than 10 years. Even though the others have half-lives less than 10 years, their activities were included to calculate the total Curies present in SB3 at the selected decay times. The second detector was a Be thin window, semi-planar, high purity germanium detector. This detector has a high counting efficiency for low energy gamma rays $(37.2 \mathrm{keV})$ that are used to measure Sn-121m. The Sn-121m concentration was so low that it was not detected. Again to obtain a reliable low detection limit, each of the four aliquots was counted for 13.9 hours.

\subsubsection{I-129 Method}

The radionuclide I-129 is a long-lived beta emitting fission product ( $\mathrm{t}_{1 / 2}=1.6 \mathrm{E} 07$ years) that is in SRS wastes. This radionuclide was not detected by the ICP-MS in the dissolved dried sludge slurry samples. The ADS has developed a special procedure to determine the I-129. Three samples of the dried sludge slurry were dissolved in presence of a known amount of KI carrier. The resulting solution was further treated to remove Cs-137 and actinide elements. The solution was then treated with $\mathrm{AgNO}_{3}$ in order to precipitate the iodide ion as AgI. The precipitate was removed from the Shielded Cells and counted by gamma spectroscopy to determine the amount of I-129 present. I-129, if present, is detected by its characteristic gamma ray. In SB3, no I-129 was detectable. Therefore, the detection limit for I-129 was used as input to the SB3 reportable isotope projection calculations.

\subsubsection{Pu-238/-241 Method}

$\mathrm{Pu}-241$ is a beta-emitting $\mathrm{Pu}$ isotope that cannot be measured directly in the dissolved dried sludge slurry solutions because of its low concentration. Pu-241 has a relatively short half-life (15 years). Its concentration, along with that for Pu-238, was determined by isolating the Pu from each solution by a thenoyltrifluoroacetone extraction procedure. The extracted Pu was then analyzed by beta and alpha counting to determine the ratio of beta activity from $\mathrm{Pu}-241$ to the alpha activity from the other isotopes of $\mathrm{Pu}(\mathrm{Pu}-238, \mathrm{Pu}-239, \mathrm{Pu}-240$, and $\mathrm{Pu}-242)$. In the original dissolution solutions, the total alpha activity from the Pu isotopes was determined by alpha counting and ICP-MS. Knowing the total alpha activity from $\mathrm{Pu}$ in the solutions resulting from the extraction allows the concentration of $\mathrm{Pu}-241$ in the original dissolution solutions to be calculated using the beta/alpha ratio determined in the extracted solution. In the extracted solution, the alpha counting technique also gives the alpha counts due specifically to $\mathrm{Pu}-$ 238 so that the total amount of Pu-238 can be determined. The activities of these two radionuclides were then used in the calculations to determine the reportable radionuclides.

\subsubsection{Am/Cm Method}

This method was used for Am-241, Am-242m, Am-243, Cm-242, Cm-243, Cm-244, Cm-247, Cf-249, Cf-250, and Cf-251. These radionuclides are neutron activation products produced in the SRS reactors. These isotopes are difficult to measure because of their low concentrations in the sludge slurry and the dilutions necessary to get the dissolved slurry samples out of the Shielded Cells. Of these isotopes, the Am-241 can be easily and accurately analyzed directly by long term gamma counting of the dissolved sludge (see Section 2.1.2). For the other radionuclides listed above, a separation method has been has developed by ADS for isolating Am, Cm and Cf from a dissolved dried sludge slurry solution using a commercially available ion exchange resin. The solution is passed through the column to extract the Am, Cm and Cf. These elements are then eluted from the resin and the solution analyzed by alpha and

gamma counting techniques. The radionuclides Cm-242, Cm-244, and Cf-250 were analyzed by alpha counting and the remaining isotopes by gamma counting. The fraction of each actinide element isolated by this ion exchange technique was determined by comparing the measured concentrations of Am-241 in the eluted solutions with their respective concentration in the original dissolved slurry that was measured 
by direct gamma counting. The percent recovery for the method based on Am-241 was 93\%. These recoveries were applied to the alpha and gamma analyses of their respective eluted solutions and the concentrations of the other radionuclides calculated.

By using this technique, the radionuclides Am-243 and Cm-244 were detected and measured along with the Am-241. All the other radionuclides had concentrations below the detection limit of the analytical method. These radionuclides were Am-242m, Cm-242, Cm-243, Cm-247, Cf-249, Cf-250, and Cf-251. For these, the detection limits were then used as the maximum concentrations or activities that could be present. However the alpha counting technique cannot differentiate between Cm-242 and Cf-250. Both have alpha particles of nearly the same energy $(6.0 \mathrm{MeV})$. Consequently, the activities of both Cm-242 and Cf-250 in the input for the calculations are identical and are the lowest detection limits measured for the $6.0 \mathrm{MeV}$ alpha particles. All the other radionuclides had alpha particle energies that could be distinctly measured by this technique. Even though $\mathrm{Cm}-242$ has a half-life of less than 10 years, $\left(t_{1 / 2}=162\right.$ days) it was included to calculate the total Curie content of the SB3 sample as a function of time.

\subsection{Calculated Activities of the Remaining Radionuclides}

\subsubsection{Pd-107}

The noble metal Pd-107 is a pure beta emitter with a very long half-life (6.5E06 years). This radionuclide could not be detected in the SB3 dissolved dried slurry samples by ICP-MS due to the presence of natural silver. Natural Ag contains the isotope Ag-107 which interferes with the measurement of Pd-107. The concentration of Pd-105 could be measured in the solutions thus the concentration of Pd-107 was calculated from the concentration of Pd-105. This was done by multiplying the ratio of the product of the fission yields and masses for Pd-107 and Pd-105 by the measured wt \% for Pd-105 as determined by ICP-MS.

\subsubsection{Cs-135}

The radionuclide Cs-135 cannot be detected by ICP-MS in the sludge slurry due to its low concentration and the large amount of natural Ba-135 (same mass as the Cs-135). Cs-135 cannot be detected by counting techniques either because of its long half-life $\left(\mathrm{t}_{1 / 2}=2.3 \mathrm{E}+06\right.$ years $)$. The detection by ICP-MS of Cs-135 in the supernate is possible because Ba-135 is insoluble in caustic supernate. The same philosophy applies to Ba-137 and Cs-137. Thus, Ba does not interfere with the analyses of Cs-135 or Cs-137 in the supernate. By using the ratio of Cs-135 to Cs-137 in the supernate, and the amount of Cs137 in the sludge slurry, the activity for Cs-135 in the sludge slurry can be calculated. For SB1B and SB2, the average value for the ratio of the masses of Cs- 135 to Cs- 137 was $0.32 \pm 0.04^{16,17}$. This ratio in SB3 should be similar to that in SB1B and SB2 due the age of the sludge and intra-tank mixing through the years. Consequently this ratio was used to estimate the weight percent of Cs-135 in the samples of SB3 using the measured mass of Cs-137. The weight percent of Cs-135 was then converted to $\mu \mathrm{Ci} / \mathrm{g}$ and used in the calculations to determine if Cs-135 was reportable.

\subsubsection{Pm-147}

The radionuclide Pm-147 is a beta emitter that has a half-life of 2.63 years. This is shorter than 10 years and thus Pm-147 does not qualify as a reportable radionuclide. However, in the sludge at year 2005, the Pm-147 can contribute to the total Curies in the sludge. The analysis of Pm-147 in dissolved dried sludge slurry solutions is somewhat extensive and was not performed for SB3. As an alternative, its concentration was calculated by assuming that all of the beta activity (Curies) that was not measured was due to Pm-147. The total measured beta activity was $1.15 \mathrm{E}+04 \mu \mathrm{Ci} / \mathrm{g}$ as described in Section 2.1.3. The calculated total beta activity for all the measured beta emitters was $1.03 \mathrm{E}+04 \mu \mathrm{Ci} / \mathrm{g}$. Subtracting these values leaves $1.2 \mathrm{E}+03 \mu \mathrm{Ci} / \mathrm{g}$ for the Pm-147 activity. This was added to the input activities to calculate 
the total activity of the SB3 sample as a function of time. Due to the short half-life of Pm-147, including it had no effect on which radionuclides were reportable and which were not.

\subsubsection{Cm-245 and Cm-246}

These two radionuclides of $\mathrm{Cm}$ were not detected in the solutions from the Am/Cm separation method described in Section 2.2.7. However, both of these radionuclides, as well as Cm-244, were detected by special ICP-MS analysis of the solutions resulting from the Aqua Regia dissolutions of the dried sludge slurry $^{9}$. The solutions analyzed by the ICP-MS were measured with only a $10 x$ dilution rather than the more typical 1000x dilution. As a result, the calibration of the instrument was affected by the relatively high concentrations of other components in the solution. However, Cm-244, Cm-245, and Cm-246 were definitely detected in measurable quantities, even though the instrument calibration was affected by the high concentrations of other components in the solutions. This matrix effect on the absolute concentration did not affect the relative concentration of the $\mathrm{Cm}$ isotopes since they would all be similarly affected. Consequently, the relative responses of the $\mathrm{Cm}$ isotopes would be a reliable measure of the relative concentrations of the Cm isotopes. The ratios of the responses of Cm-245 and Cm-246 to $\mathrm{Cm}-244$ were 0.073 and 0.062 , respectively. In the $\mathrm{Am} / \mathrm{Cm}$ separation method an accurate determination of Cm-244 was obtained by alpha counting the separated Am-Cm-Cf solution. Based on the reliable determination of the $\mathrm{Cm}-244$ concentration in the solution of the dissolved dried slurry samples, and the ratios determined above, the concentrations of Cm-245 and Cm-246 were calculated. These concentrations were converted to activities and were used in the calculation of the reportable radionuclides.

\subsubsection{Cm-248}

The radionuclide Cm-248 is another radionuclide that needs to be considered as possibly reportable but which cannot be measured due to its low concentration. The concentration of this isotope had to be estimated using the ratio of $\mathrm{Cm}-248$ to $\mathrm{Cm}-247$ predicted for the DWPF design basis glass ${ }^{11}$. The predicted ratio of the mass of $\mathrm{Cm}-248$ to the mass of $\mathrm{Cm}-247$ was 0.023 . An upper limit of the concentration of Cm-248 was calculated by multiplying the upper limit for the concentration of Cm-247 measured by the Am/Cm method by this ratio. This upper limit was then converted to activity of Cm248 using the specific activity of Cm-248. This result was entered into the reportable isotope projection calculations. 
WSRC-TR-2005-00157

Revision 0

This page intentionally left blank. 


\subsection{RESULTS AND DISCUSSION}

\subsection{Summary of the Activities and Radionuclides for Input}

The complete list of radionuclides and their activities that were considered in the determination of reportable radionuclides are provided in Table 3-1. For those radionuclides with measured concentrations, the initial activities were calculated by using the weight percent reported for each radioisotope and its specific activity with the following equation: $A_{0}=M_{0} * S p A$, where $A_{0}=$ Initial Activity, $\mathrm{M}_{0}=$ mass in weight percent and $\mathrm{SpA}=$ specific activity of the isotope.

For each radionuclide listed in Table 3-1 there is an associated specific activity in units of Ci/g, wt\% of total solids, activity in $\mu \mathrm{Ci} / \mathrm{g}$, and the method used to determine or estimate the value.

The total alpha activity of the digested samples was below the detection limit of the counting procedure and is reported as $<160 \mu \mathrm{Ci} / \mathrm{g}$. The calculated alpha activity of the samples is $116 \mu \mathrm{Ci} / \mathrm{g}$. Total beta activity was measured at $1.15 \mathrm{E}+4 \mu \mathrm{Ci} / \mathrm{g}$. 
WSRC-TR-2005-00157

Revision 0

Table 3-1. List of Radionuclides and Activities Used as Input to the RadDecay ${ }^{\circledR}$ Program

\begin{tabular}{|c|c|c|c|c|}
\hline Radionuclide & $\begin{array}{c}\text { Specific Activity } \\
\text { (Ci/g) }\end{array}$ & Wt\% & $\begin{array}{l}\text { Activity } \\
(\mu \mathrm{Ci} / \mathrm{g}) \ddagger\end{array}$ & Method \\
\hline Ni-59 & $8.08 \mathrm{E}-02$ & $8.21 \mathrm{E}-04$ & 6.63E-01 & Ni-59/-63 \\
\hline Co-60 & $1.13 \mathrm{E}+03$ & 1.43E-07 & $1.62 \mathrm{E}+00$ & Direct Gamma Counting \\
\hline $\mathrm{Ni}-63$ & $6.17 \mathrm{E}+01$ & 8.77E-05 & $5.41 \mathrm{E}+01$ & Ni-59/-63 \\
\hline Se-79 & 6.97E-02 & 2.83E-05 & $<1.97 \mathrm{E}-02$ & Se-79 \\
\hline Sr-90 & $1.36 \mathrm{E}+02$ & $3.56 \mathrm{E}-03$ & $4.85 E+03$ & Sr-90 \\
\hline $\mathrm{Y}-90 *$ & $5.44 \mathrm{E}+05$ & 8.92E-07 & $4.85 E+03$ & Secular equilibrium w/ Sr-90 \\
\hline Zr-93 & $2.51 \mathrm{E}-03$ & $1.76 \mathrm{E}-03$ & 4.43E-02 & ICP-MS \\
\hline Tc-99 & $1.70 \mathrm{E}-02$ & $1.15 \mathrm{E}-03$ & $1.96 \mathrm{E}-01$ & ICP-MS \\
\hline Pd-107 & $5.14 \mathrm{E}-04$ & $1.34 \mathrm{E}-04$ & 6.89E-04 & Calculated from Pd-105 \\
\hline $\mathrm{Sn}-121 \mathrm{~m}$ & $5.91 \mathrm{E}+01$ & 3.96E-06 & $<2.34 \mathrm{E}+00$ & Cs-Removed Gamma Counting \\
\hline Sb-125 & $1.03 \mathrm{E}+03$ & 8.03E-09 & $<8.29 \mathrm{E}-02$ & Cs-Removed Gamma Counting \\
\hline Te-125m* & $1.80 \mathrm{E}+04$ & $4.60 \mathrm{E}-10$ & $<8.29 \mathrm{E}-02$ & Secular equilibrium w/ Sb-125 \\
\hline Sn-126 & 2.84E-02 & 5.01E-05 & $<1.42 \mathrm{E}-02$ & Cs-Removed Gamma Counting \\
\hline $\mathrm{I}-129$ & $1.77 \mathrm{E}-04$ & 2.46E-04 & $<4.35 \mathrm{E}-04$ & $\mathrm{I}-129$ \\
\hline Cs-135 & $1.15 \mathrm{E}-03$ & $1.16 \mathrm{E}-04$ & $1.34 \mathrm{E}-03$ & Calculated from Cs-135/-137 ratio \\
\hline Cs-137 & $8.70 \mathrm{E}+01$ & 3.63E-04 & $3.15 E+02$ & Direct Gamma Counting \\
\hline Ва-137m* & $5.38 \mathrm{E}+08$ & 5.63E-11 & $3.03 E+02$ & Secular equilibrium w/ Cs-137 \\
\hline Pm-147 & $9.27 \mathrm{E}+02$ & $1.29 \mathrm{E}-04$ & $1.20 \mathrm{E}+03$ & Calculated from $\beta$-Activity \\
\hline Sm-151 & 2.63E+01 & $7.44 \mathrm{E}-04$ & $1.96 \mathrm{E}+02$ & ICP-MS \\
\hline Eu-154 & $2.70 \mathrm{E}+02$ & 2.87E-06 & $7.73 \mathrm{E}+00$ & Direct Gamma Counting \\
\hline Eu-155 & $4.65 \mathrm{E}+02$ & $4.55 \mathrm{E}-07$ & $2.12 \mathrm{E}+00$ & Direct Gamma Counting \\
\hline Th-232 & $1.10 \mathrm{E}-07$ & $2.74 \mathrm{E}-02$ & 3.01E-05 & ICP-MS \\
\hline U-233 & $9.68 \mathrm{E}-03$ & 1.61E-04 & $1.56 \mathrm{E}-02$ & ICP-MS \\
\hline U-234 & $6.25 \mathrm{E}-03$ & 4.84E-04 & 3.03E-02 & ICP-MS \\
\hline U-235 & $2.16 \mathrm{E}-06$ & 3.38E-02 & 7.29E-04 & ICP-MS \\
\hline U-236 & $6.47 \mathrm{E}-05$ & $1.31 \mathrm{E}-03$ & $8.46 \mathrm{E}-04$ & ICP-MS \\
\hline Np-237 & 7.05E-04 & 4.68E-03 & 3.30E-02 & ICP-MS \\
\hline U-238 & 3.36E-07 & $6.73 \mathrm{E}+00$ & 2.26E-02 & ICP-MS \\
\hline $\mathrm{Pu}-238$ & $1.71 \mathrm{E}+01$ & $1.51 \mathrm{E}-04$ & $2.59 \mathrm{E}+01$ & Pu-238/-241 \\
\hline Pu-239 & $6.22 \mathrm{E}-02$ & $2.20 \mathrm{E}-02$ & $1.37 \mathrm{E}+01$ & ICP-MS \\
\hline $\mathrm{Pu}-240$ & 2.28E-01 & 2.11E-03 & $4.80 \mathrm{E}+00$ & ICP-MS \\
\hline $\mathrm{Pu}-241$ & $1.03 \mathrm{E}+02$ & $5.26 \mathrm{E}-05$ & $5.42 \mathrm{E}+01$ & $\mathrm{Pu}-238 /-241$ \\
\hline $\mathrm{Pu}-242$ & $3.82 \mathrm{E}-03$ & 1.43E-04 & $5.46 \mathrm{E}-03$ & ICP-MS \\
\hline Am-241 & $3.43 \mathrm{E}+00$ & $5.40 \mathrm{E}-04$ & $1.85 \mathrm{E}+01$ & Direct Gamma Counting \\
\hline Am-242m & $9.72 \mathrm{E}+00$ & 9.19E-07 & $<8.93 \mathrm{E}-02$ & $\mathrm{Am} / \mathrm{Cm}$ \\
\hline Am-243 & $1.99 \mathrm{E}-01$ & 7.77E-04 & $1.55 \mathrm{E}+00$ & $\mathrm{Am} / \mathrm{Cm}$ \\
\hline Cm--242 & $3.31 \mathrm{E}+03$ & $2.26 \mathrm{E}-10$ & $<7.46 \mathrm{E}-03$ & $\mathrm{Am} / \mathrm{Cm}$ \\
\hline $\mathrm{Cm}-243$ & $5.16 \mathrm{E}+01$ & 4.94E-07 & $<2.55 \mathrm{E}-01$ & $\mathrm{Am} / \mathrm{Cm}$ \\
\hline $\mathrm{Cm}-244$ & $8.09 \mathrm{E}+01$ & 8.66E-05 & $7.00 \mathrm{E}+01$ & $\mathrm{Am} / \mathrm{Cm}$ \\
\hline $\mathrm{Cm}-245$ & $1.72 \mathrm{E}-01$ & 6.35E-06 & $1.09 \mathrm{E}-02$ & ICP-MS 10x Cm-245/-244 Ratio \\
\hline $\mathrm{Cm}-246$ & 3.07E-01 & $5.26 \mathrm{E}-06$ & $1.62 \mathrm{E}-02$ & ICP-MS 10x Cm-246/-244 Ratio \\
\hline $\mathrm{Cm}-247$ & $9.28 \mathrm{E}-05$ & 2.86E-02 & $<2.65 \mathrm{E}-02$ & $\mathrm{Am} / \mathrm{Cm}$ \\
\hline $\mathrm{Cm}-248$ & 4.25E-03 & 6.53E-04 & $<2.77 \mathrm{E}-02$ & Calculated Ratio Cm-247/-248 \\
\hline Cf-249 & $4.38 \mathrm{E}+00$ & $6.46 \mathrm{E}-07$ & $<2.83 \mathrm{E}-02$ & $\mathrm{Am} / \mathrm{Cm}$ \\
\hline Cf-250 & $1.09 \mathrm{E}+02$ & $6.82 \mathrm{E}-09$ & $<7.46 \mathrm{E}-03$ & $\mathrm{Am} / \mathrm{Cm}$ \\
\hline \multirow[t]{2}{*}{ Cf-251 } & $1.86 \mathrm{E}+00$ & $1.20 \mathrm{E}-06$ & $<2.24 \mathrm{E}-02$ & $\mathrm{Am} / \mathrm{Cm}$ \\
\hline & Total & & $1.20 \mathrm{E}+04$ & \\
\hline
\end{tabular}

* Included because this isotope is in secular equilibrium with a parent for which a measured value was available.

$\ddagger$ Less than values represent the minimum detection limit value and hence are an upper bound for that isotope’s activity. 


\subsection{Identification of Reportable Radionuclides}

Based on radionuclides and activities provided in Table 3-1, a commercially available computer program was used to identify which radionuclides were reportable through calendar year 3115. The program is called RadDecay ${ }^{\circledR}$ version $2.0^{12}$

The initial activities for 46 isotopes were entered into RadDecay ${ }^{\circledR}$ and the results of two calculations with the time periods of ten years (2015) and 1110 years (3115) are presented in Appendix A and Appendix B. Those radionuclides that are reportable are designated in these tables by a "yes". Additional calculations were performed for every 100 years up to 1100 years. The results of these calculations have not been included in this report but are documented in a laboratory notebook. Microsoft Excel spreadsheets were used to calculate the total activity in $\mu \mathrm{Ci} / \mathrm{g}$ of dried sludge solids at each time and the percent of the activity that each of the radionuclides contributed.

The calculations performed by RadDecay ${ }^{\circledR}$ v. 2.0 were verified by a separate program called Radioactive Decay Calculator ${ }^{13}$. A comparison between the outputs of the two programs for the years 2015, 2715, and 3115 gave the same list of reportable radionuclides, with the exception of Sn-121m which is not included in the Radioactive Decay Calculator, though it remains a reportable isotope. In addition to this check, a separate independent evaluation utilizing the input radionuclides and an earlier version of RadDecay ${ }^{\circledR}$ v. 1.13 was conducted. The reportable radionuclides determined by this evaluation were also the same as those reported here. The results of the calculations with RadDecay ${ }^{\circledR}$ v.2.0 for each 100 year interval starting in 2015 through 3115 are given in Appendices A - L. Both software packages have a software QA classification of "C" $\mathrm{C}$ " and are covered by a Software QA Plan"

The total Curie content of the dried sludge in the year 2015 is $8.61 \mathrm{E}+03 \mu \mathrm{Ci} / \mathrm{g}$. This value is greater than the $4.45 \mathrm{E}+03 \mu \mathrm{Ci} / \mathrm{g}$ total represented by the reportable radionuclides in Appendix A. The difference is due to the significant contribution to the activity from radionuclides having half-lives shorter than ten years. These radionuclides include (in decreasing order of activity contribution): Y-90, Ba-137m, Pm-147, Eu-154, Sn-121, and Np-239. The need to exclude some of these minor and metastable isotopes due to input limitations with the Radioactive Decay Calculator resulted in a minor difference in the total activity calculated for the year 2015 between this report and the verification check which was performed in support of this work $(8.57 \mathrm{E}+02 \mu \mathrm{Ci} / \mathrm{g}$ versus $8.61 \mathrm{E}+02)$.

Appendix L presents the reportable radionuclides indexed to the year 3115. The total Curie content of the dried sludge in 3115 is $2.54 \mathrm{E}+01 \mu \mathrm{Ci} / \mathrm{g}$. This value is slightly greater than the $2.39 \mathrm{E}+01 \mu \mathrm{Ci} / \mathrm{g}$ total represented by the radionuclides identified as reportable. The difference is due to the minor contribution to the total activity from radionuclides having half-lives shorter than 10 years. These radionuclides include (in decreasing order of activity contribution): Np-239, Pa-233, Pu-243, Pa-234m = Th-234, and Sb-126m.

Thirty radionuclides have been identified as reportable for DWPF SB3 (MB4) as specified by WAPS 1.2. Consistent with the strategy detailed in the WCP and WQR, each of these radionuclides has a halflife greater than 10 years and contributes more than $0.01 \%$ of the radioactivity on a Curie basis at some point from production through the 1100-year period between 2015 and 3115 . The 30 reportable radionuclides are given in Table 3-2. The calculations at every one hundred years out to 1100 years demonstrated that only one radionuclide became reportable during this time period, Am-242m, which was reportable for the years between 2215 and 2715, but no longer reportable in 2815. The data for these intermediate year calculations can be found in Appendices B-K. 
Table 3-2. Reportable Radionuclides in DWPF Sludge Batch 3 (Macrobatch 4)

\begin{tabular}{cccccc}
\hline Ni-59 & Ni-63 & Se-79* & Sr-90 & Zr-93 & Nb-93m \\
Tc-99 & Sn-121m* & Sn-126* & Cs-137 & Sm-151 & U-233 \\
U-234 & Np-237 & U-238 & Pu-238 & Pu-239 & Pu-240 \\
Am-241 & Am-242m* & Pu-241 & Pu-242 & Am-243 & Cm-244 \\
Cm-245 & Cm-246* & Cm-247* & Cm-248* & Cf-249* & Cf-251* \\
\hline
\end{tabular}

* Based upon an analytical detection limit.

The WCP and WQR require that all of the radionuclides present in the Design Basis glass be considered as the initial set of reportable radionuclides. All of the radionuclides in the Design Basis glass are reportable except for three radionuclides: Pd-107, Cs-135, and Th-230. At no time during the 1100-year period between 2015 and 3115 did any of these three radionuclides contribute to more than $0.01 \%$ of the radioactivity on a Curie basis.

Eight of the 32 reportable radionuclides for SB3 are not part of either the design-basis list of radionuclides $^{2}$ or the list of $\mathrm{Pu}$ and $\mathrm{U}$ isotopes identified in WAPS 1.6. These include Sn-121m, Am242m, Cm-245, Cm-246, Cm-247, Cm-248, Cf-249 and Cf-251. Two of these radionuclides (Sn-121m and Cm-246 were also reported for SB1B (MB2) ${ }^{16}$ and four of these radionuclides (Sn-121m, Cm-245, Cm-246, and Cf-251) were also reported for SB2 (MB3) ${ }^{17}$. C-14, reported in the two earlier analyses, has been excluded as described in the Introduction.

The list of reportable radionuclides that were determined for SB1B (MB2) ${ }^{16}$ contained two radionuclides that were not reportable for SB2 (MB3) or in the current SB3 (MB4). These radionuclides were I-129 and Th-229. Only C-14 was reportable in SB2 (MB3) but not reportable in SB3 (MB4). For easier comparison, the reportable nuclides for SB1B and SB2 have been reproduced in Table 3-3 and Table 3-4.

Table 3-3. Reportable Radionuclides in DWPF Sludge Batch 1B (Macrobatch 2) ${ }^{16}$

\begin{tabular}{cccccc}
\hline C-14 & Ni-59 & Ni-63 & Se-79 & Sr-90 & Zr-93 \\
Nb-93m & Tc-99 & Sn-121m & Sn-126 & I-129 & Cs-137 \\
Sm-151 & Th-229 & U-233 & U-234 & Np-237 & U-238 \\
Pu-238 & Pu-239 & Pu-240 & Am-241 & Pu-241 & Pu-242 \\
Am-243 & Cm-244 & Cm-246 & & & \\
\hline
\end{tabular}

${ }^{6}$ Fellinger, T. L, Bibler, N. E., and Harbour, J. R., Characterization of and Waste Acceptance Radionuclides to be Reported for DWPF Macrobatch 2 (ESP 215 - ESP 221), WSRC-RP-99-00436, Revision 1, Savannah River Site, March 2004.

Table 3-4. Reportable Radionuclides in DWPF Sludge Batch 2 (Macrobatch 3) ${ }^{17}$

\begin{tabular}{cccccc}
\hline C-14 & Ni-59 & Ni-63 & Se-79 & Sr-90 & Zr-93 \\
Nb-93m & Tc-99 & Sn-121m & Sn-126 & Cs-137 & Sm-151 \\
U-233 & U-234 & Np-237 & U-238 & Pu-238 & Pu-239 \\
Pu-240 & Am-241 & Pu-241 & Pu-242 & Am-243 & Cm-244 \\
Cm-245 & Cm-246 & Cf-251 & & & \\
\hline
\end{tabular}

${ }^{17}$ Bibler, N. E., DiPrete, D. P., and Harbour, J. R., Determination of Reportable Radionuclides for DWPF Sludge Batch 2 (Macrobatch 3), WSRC-TR-2002-00255, Revision 0, Savannah River Site, September 2002. 


\subsection{The Ratio by Weight of $U$ and Pu Isotopes}

The WQR requires that the relative concentrations of the uranium and plutonium isotopes be provided from the analysis of each Macrobatch (in this case Sludge Batch 3) in order to meet the WAPS IAEA Safeguards Reporting for HLW Specification (WAPS 1.6). The data for uranium isotopes are given in Table 3-5.

Table 3-5. Uranium Isotope Distribution in DWPF Sludge Batch 3 (Macrobatch 4)

\begin{tabular}{ccc}
\hline Isotope & Weight Percent & Percent Distribution \\
\hline $\mathrm{U}-233$ & $1.61 \mathrm{E}-04$ & 0.00238 \\
$\mathrm{U}-234$ & $4.84 \mathrm{E}-04$ & 0.00716 \\
$\mathrm{U}-235$ & $3.38 \mathrm{E}-02$ & 0.499 \\
$\mathrm{U}-236$ & $1.31 \mathrm{E}-03$ & 0.0193 \\
$\mathrm{U}-238$ & $6.73 \mathrm{E}+00$ & 99.5 \\
\hline Total & $6.76 \mathrm{E}+00$ & 100 \\
\hline
\end{tabular}

The data for the plutonium isotopes is given in Table 3-6.

Table 3-6. Plutonium Isotope Distribution in DWPF Sludge Batch 3 (Macrobatch 4)

\begin{tabular}{ccc}
\hline Isotope & Weight Percent & Percent Distribution \\
\hline Pu-238 & $1.51 \mathrm{E}-04$ & 0.619 \\
Pu-239 & $2.20 \mathrm{E}-02$ & 90.0 \\
Pu-240 & $2.11 \mathrm{E}-03$ & 8.62 \\
Pu-241 & $5.26 \mathrm{E}-05$ & 0.215 \\
Pu-242 & $1.43 \mathrm{E}-04$ & 0.585 \\
\hline Total & $2.45 \mathrm{E}-02$ & 100 \\
\hline
\end{tabular}

All of the Pu isotopes and U-233, -234 , and -238 are already reportable since they meet the requirement of having half-lives greater than 10 years and a contribution to the overall activity of greater than $0.01 \%$ on a Curie basis through the year 3115. In order to be compliant with WAPS 1.6, U-235 and U-236 also become reportable even though they contribute less than $0.01 \%$ to the total activity (U-235 at $0.003 \%$ and U-236 at $0.004 \%$ in 3115). 
WSRC-TR-2005-00157

Revision 0

This page intentionally left blank. 


\subsection{CONCLUSIONS}

Thirty radionuclides have been identified as reportable for DWPF SB3 (MB4) as specified by WAPS 1.2. Consistent with the strategy detailed in the WCP and WQR, each of these radionuclides has a halflife greater than ten years and contributes more than $0.01 \%$ of the radioactivity on a Curie basis at some point from production through the 1100 year period between 2015 and 3115 . The 30 reportable nuclides are:

\begin{tabular}{cccccc}
\hline Ni-59 & Ni-63 & Se-79 & Sr-90 & Zr-93 & Nb-93m \\
Tc-99 & Sn-121m & Sn-126 & Cs-137 & Sm-151 & U-233 \\
U-234 & Np-237 & U-238 & Pu-238 & Pu-239 & Pu-240 \\
Am-241 & Am-242m & Pu-241 & Pu-242 & Am-243 & Cm-244 \\
Cm-245 & Cm-246 & Cm-247 & Cm-248 & Cf-249 & Cf-251 \\
\hline
\end{tabular}

The WCP and WQR require that all of radionuclides present in the Design Basis glass be considered as the initial set of reportable radionuclides. For SB3 (MB4) all of the radionuclides in the Design Basis glass are reportable except for three radionuclides: Pd-107, Cs-135, and Th-230. At no time through the calendar year 3115 did any of these three radionuclides contribute to more than $0.01 \%$ of the radioactivity on a Curie basis.

Two additional uranium isotopes (U-235 and -236) must be added to the list of reportable radionuclides in order to meet WAPS 1.6. All of the Pu isotopes and other $U$ isotopes (U-233, -234, and -238) identified in WAPS 1.6 were already determined to be reportable according to WAPS 1.2 This brings the total number of reportable radionuclides for SB3 to thirty-two. 
WSRC-TR-2005-00157

Revision 0

This page intentionally left blank. 


\subsection{RECOMMENDATIONS}

Earlier WAPS radionuclide inventory work had additional analytical work performed. Some of these extra steps were eliminated during this WAPS inventory analysis with the belief that there would be no significant impact. For example, for SB2, the Am/Cm method was performed in the SRNL Shielded Cells with a larger portion of dissolved sludge solids, thereby producing a larger portion of the eluent with reduced activity which could be removed from the Cells. This larger eluent can be more accurately counted for Cm-247, Cf-249, and Cf-251. This in turn would improve the estimation of Cm-248. Additionally, this more concentrated eluent can be analyzed by ICP-MS, thus improving the measurement of Cm-245 and Cm-246. In hindsight, eliminating this Shielded Cells work resulted in some final radionuclide concentrations based upon detection limits rather than measured values. This in turn may have made some radionuclides reportable when they would have been non-reportable had the earlier methodology been repeated and more precise measurements obtained. In the future, it is recommended that this issue be examined further to determine if reducing the number of reportable radionuclides to the greatest extent possible is important. 
WSRC-TR-2005-00157

Revision 0

This page intentionally left blank. 


\subsection{REFERENCES}

${ }^{1}$ Office of Environmental Management, Waste Acceptance Product Specifications for Vitrified HighLevel Waste Forms, USDOE Document DOE/EM-0093, Rev. 2, December 1996.

${ }^{2}$ Westinghouse Savannah River Company, DWPF Waste Form Compliance Plan, WSRC-IM-91-116-0, Rev. 7, Savannah River Site, June 2003.

${ }^{3}$ Westinghouse Savannah River Company, DWPF Waste Form Qualification Report, Volume 4: Reporting the Radionuclides Inventory of the DWPF Product, WSRC-IM-91-116-4, Rev. 2, Savannah River Site, June 2003.

${ }^{4}$ Rios-Armstrong, M. A., Technical Task Request: Sludge Batch 3 SRTC Shielded Cells Testing, WLW/DWPF/TTR-03-0005, Revision 1, Savannah River Site, June 2003.

${ }^{5}$ Pareizs, J. M., Task Technical and Quality Assurance Plan: Washing and Qualification of Sludge Batch 3 Radioactive Sludge Slurry, WSRC-RP-2003-00249, Revision 1, Savannah River Site, June 2003.

${ }^{6}$ Pareizs, J. M., Analytical Study Plan: Characterization of the Tank 40 Sludge Batch 3 Sample, WSRCRP-2004-00262, Revision 0, Savannah River Site, March 2004.

${ }^{7}$ Bibler, N. E. and Fowler, J. R., Technical Basis for Eliminating Carbon-14 as a Reportable Radionuclide In DWPF Glass, WSRC-TR-2004-00629, Revision 0, Savannah River Site, December 2004.

${ }^{8}$ Hyder, M. L., Waste Acceptance Radionuclides to be Reported in Tank 51 Sludge Only Glass, WSRCTR-95-0485, Revision 0, Savannah River Site, December 1995.

${ }^{9}$ Bannochie, C. J., Fellinger, T. L., and Pareizs, J. M., Tank 40 Final SB3 Chemical Characterization Results, WSRC-TR-2005-00049, Revision 0, Savannah River Site, January 2005.

${ }^{10}$ Integrated Data Base Report - 1994: U. S. Spent Nuclear Fuel and Radioactive Waste Inventories, Projections, and Characteristics, DOE/RW-0006, Rev. 11, Oak Ridge National Laboratory, September 1995.

${ }^{11}$ Baxter, R. G., Defense Waste Processing Facility Wasteform and Canister Description, DP-1606, Revision 2, Savannah River Site, December 1988.

${ }^{12}$ RadDecay, Version 2.0, Grove Software, Inc., Lynchburg, VA 24502.

${ }^{13}$ Radioactive Decay Calculator, D. W. James \& Associates, North Oaks, MN 55127.

${ }^{14}$ Bannochie, C. J., Radioactive Decay Modeling Using RadDecay and Radioactive Decay Calculator Software Classification, WSRC-RP-2005-01585, Savannah River Site, May 2005.

${ }^{15}$ Pareizs, J. M. and Bannochie, C. J., Software Quality Assurance Plan and Acceptance Testing for Commercial Radioactive Decay Calculation Packages Utilized by the Immobilization Technology Section, G-SQP-A-00006, Savannah River Site, May 2005. 
WSRC-TR-2005-00157

Revision 0

${ }^{16}$ Fellinger, T. L, Bibler, N. E., and Harbour, J. R., Characterization of and Waste Acceptance Radionuclides to be Reported for DWPF Macro Batch 2 (ESP 215 - ESP 221), WSRC-RP-99-00436, Revision 1, Savannah River Site, March 2004.

${ }^{17}$ Bibler, N. E., DiPrete, D. P., and Harbour, J. R., Determination of Reportable Radionuclides for DWPF Sludge Batch 2 (Macro Batch 3), WSRC-TR-2002-00255, Revision 0, Savannah River Site, September 2002. 


\subsection{ACKNOWLEDGEMENTS}

The authors would like to acknowledge the support of the SRNL Shielded Cells technicians and supervision. Additionally, we would like to thank ADS personnel Bill Boyce for accommodating all our additional ICP-MS data analysis requirements, and Cici and David DiPrete for all their "non-routine” counting analyses and helpful consultations. 
WSRC-TR-2005-00157

Revision 0

This page intentionally left blank. 
WSRC-TR-2005-00157

Revision 0

\section{APPENDIX A. ACTIVITIES OF DRIED SLUDGE IN YEAR $2015(\mu \mathrm{Ci} / \mathrm{g})$}


WSRC-TR-2005-00157

Revision 0

\begin{tabular}{|c|c|c|c|}
\hline Nuclide & $\begin{array}{l}\text { Y } 2015 \\
\mu \mathrm{Ci} / \mathrm{g}\end{array}$ & $\begin{array}{c}\text { Fraction of } \\
\text { Activity }\end{array}$ & Reportable \\
\hline Ac-225 & $1.46 \mathrm{E}-05$ & 1.69E-09 & \\
\hline Ac-227 & 2.21E-08 & 2.57E-12 & \\
\hline Ac-228 & 2.11E-05 & 2.45E-09 & \\
\hline Am-241 & $1.89 \mathrm{E}+01$ & 2.19E-03 & Yes \\
\hline Am-242 & 8.49E-02 & 9.86E-06 & \\
\hline Am-242m & 8.53E-02 & 9.91E-06 & \\
\hline Am-243 & $1.55 \mathrm{E}+00$ & 1.80E-04 & Yes \\
\hline At-217 & 1.46E-05 & 1.69E-09 & \\
\hline At-218 & 1.19E-12 & $1.38 \mathrm{E}-16$ & \\
\hline Ba-137m & $2.37 \mathrm{E}+02$ & 2.75E-02 & \\
\hline Bi-210 & 5.64E-10 & $6.55 E-14$ & \\
\hline Bi-211 & 2.16E-08 & 2.51E-12 & \\
\hline Bi-212 & 1.70E-05 & 1.97E-09 & \\
\hline Bi-213 & 1.46E-05 & 1.69E-09 & \\
\hline Bi-214 & 5.93E-09 & 6.89E-13 & \\
\hline Cf-249 & 2.77E-02 & $3.22 \mathrm{E}-06$ & \\
\hline Cf-250 & 4.39E-03 & 5.10E-07 & \\
\hline Cf-251 & 2.22E-02 & $2.58 \mathrm{E}-06$ & \\
\hline $\mathrm{Cm}-242$ & 7.04E-02 & 8.18E-06 & \\
\hline Cm-243 & 2.00E-01 & 2.32E-05 & \\
\hline $\mathrm{Cm}-244$ & 4.77E+01 & 5.55E-03 & Yes \\
\hline Cm-245 & 1.09E-02 & 1.27E-06 & \\
\hline Cm-246 & 1.62E-02 & 1.88E-06 & \\
\hline $\mathrm{Cm}-247$ & 2.65E-02 & 3.08E-06 & \\
\hline $\mathrm{Cm}-248$ & $2.77 \mathrm{E}-02$ & $3.22 \mathrm{E}-06$ & \\
\hline Co-60 & 4.35E-01 & 5.05E-05 & \\
\hline Cs-135 & 1.34E-03 & 1.56E-07 & \\
\hline Cs-137 & $2.50 \mathrm{E}+02$ & 2.91E-02 & Yes \\
\hline Eu-154 & $3.52 \mathrm{E}+00$ & 4.09E-04 & \\
\hline Eu-155 & 5.24E-01 & 6.09E-05 & \\
\hline Fr-221 & 1.46E-05 & 1.69E-09 & \\
\hline Fr-223 & 3.05E-10 & 3.55E-14 & \\
\hline |-129 & 4.35E-04 & 5.05E-08 & \\
\hline $\mathrm{Nb}-93 \mathrm{~m}$ & 1.77E-02 & 2.06E-06 & \\
\hline Ni-59 & 6.63E-01 & 7.70E-05 & \\
\hline $\mathrm{Ni}-63$ & $5.03 \mathrm{E}+01$ & 5.85E-03 & Yes \\
\hline Np-237 & 3.31E-02 & 3.84E-06 & \\
\hline Np-238 & 4.06E-04 & 4.72E-08 & \\
\hline Np-239 & $1.55 \mathrm{E}+00$ & 1.80E-04 & \\
\hline $\mathrm{Np}-240 \mathrm{~m}$ & 2.13E-09 & 2.47E-13 & \\
\hline Pa-231 & 1.54E-07 & 1.79E-11 & \\
\hline $\mathrm{Pa}-233$ & 3.31E-02 & 3.84E-06 & \\
\hline $\mathrm{Pa}-234$ & 7.45E-05 & 8.66E-09 & \\
\hline $\mathrm{Pa}-234 \mathrm{~m}$ & 2.26E-02 & 2.62E-06 & \\
\hline Pb-209 & 1.46E-05 & 1.69E-09 & \\
\hline $\mathrm{Pb}-210$ & 5.67E-10 & 6.59E-14 & \\
\hline $\mathrm{Pb}-211$ & 2.16E-08 & 2.51E-12 & \\
\hline $\mathrm{Pb}-212$ & 1.70E-05 & 1.97E-09 & \\
\hline $\mathrm{Pb}-214$ & 5.93E-09 & 6.89E-13 & \\
\hline Pd-107 & 6.89E-04 & 8.01E-08 & \\
\hline Pm-147 & $8.55 \mathrm{E}+01$ & 9.93E-03 & \\
\hline Po-210 & $4.82 \mathrm{E}-10$ & 5.61E-14 & \\
\hline Po-211 & 6.06E-11 & 7.04E-15 & \\
\hline Po-212 & 1.09E-05 & 1.26E-09 & \\
\hline Po-213 & 1.43E-05 & 1.66E-09 & \\
\hline Рo-214 & 5.93E-09 & 6.88E-13 & \\
\hline Po-215 & 2.16E-08 & 2.51E-12 & \\
\hline Po-216 & 1.70E-05 & 1.97E-09 & \\
\hline
\end{tabular}

\begin{tabular}{|c|c|c|c|}
\hline Nuclide & $\begin{array}{l}\text { Y } 2015 \\
\mu \mathrm{Ci} / \mathrm{g}\end{array}$ & $\begin{array}{c}\text { Fraction of } \\
\text { Activity }\end{array}$ & Reportable \\
\hline Po-218 & $5.93 E-09$ & 6.89E-13 & \\
\hline Pu-238 & $2.39 E+01$ & 2.78E-03 & Yes \\
\hline Pu-239 & $1.37 \mathrm{E}+01$ & 1.59E-03 & Yes \\
\hline Pu-240 & $4.86 \mathrm{E}+00$ & 5.64E-04 & Yes \\
\hline Pu-241 & $3.35 E+01$ & 3.89E-03 & Yes \\
\hline Pu-242 & $5.46 \mathrm{E}-03$ & $6.35 E-07$ & \\
\hline Pu-243 & 2.65E-02 & 3.08E-06 & \\
\hline Pu-244 & 2.13E-09 & $2.48 \mathrm{E}-13$ & \\
\hline Ra-223 & 2.16E-08 & $2.51 E-12$ & \\
\hline $\mathrm{Ra}-224$ & 1.70E-05 & 1.97E-09 & \\
\hline $\mathrm{Ra}-225$ & 1.46E-05 & 1.70E-09 & \\
\hline $\mathrm{Ra}-226$ & 5.94E-09 & $6.91 E-13$ & \\
\hline $\mathrm{Ra}-228$ & 2.11E-05 & 2.45E-09 & \\
\hline Rn-219 & 2.16E-08 & $2.51 E-12$ & \\
\hline $\mathrm{Rn}-220$ & 1.70E-05 & 1.97E-09 & \\
\hline Rn-222 & 5.93E-09 & 6.89E-13 & \\
\hline Sb-125 & 6.79E-03 & 7.89E-07 & \\
\hline Sb-126 & 1.99E-03 & 2.31E-07 & \\
\hline Sb-126m & 1.42E-02 & 1.65E-06 & \\
\hline Se-79 & 1.97E-02 & $2.29 E-06$ & \\
\hline Sm-147 & 2.76E-08 & 3.21E-12 & \\
\hline Sm-151 & $1.81 E+02$ & $2.11 E-02$ & Yes \\
\hline Sn-121 & $1.60 E+00$ & 1.86E-04 & \\
\hline Sn-121m & $2.06 \mathrm{E}+00$ & 2.40E-04 & Yes \\
\hline Sn-126 & $1.42 \mathrm{E}-02$ & 1.65E-06 & \\
\hline Sr-90 & $3.82 E+03$ & 4.44E-01 & Yes \\
\hline Tc-99 & 1.96E-01 & 2.28E-05 & \\
\hline Te-125m & 1.64E-03 & 1.91E-07 & \\
\hline Th-227 & 2.15E-08 & $2.50 \mathrm{E}-12$ & \\
\hline Th-228 & 1.70E-05 & 1.97E-09 & \\
\hline Th-229 & 1.47E-05 & 1.71E-09 & \\
\hline Th-230 & $2.76 \mathrm{E}-06$ & $3.21 E-10$ & \\
\hline Th-231 & 7.29E-04 & 8.47E-08 & \\
\hline Th-232 & 3.01E-05 & 3.50E-09 & \\
\hline Th-234 & 2.26E-02 & 2.63E-06 & \\
\hline TI-207 & 2.16E-08 & 2.51E-12 & \\
\hline TI-208 & $6.09 E-06$ & 7.08E-10 & \\
\hline TI-209 & 3.15E-07 & 3.66E-11 & \\
\hline U-233 & 1.56E-02 & 1.81E-06 & \\
\hline U-234 & 3.10E-02 & 3.60E-06 & \\
\hline U-235 & 7.29E-04 & 8.47E-08 & \\
\hline U-236 & 8.47E-04 & $9.85 \mathrm{E}-08$ & \\
\hline U-237 & 8.22E-04 & 9.55E-08 & \\
\hline U-238 & 2.26E-02 & 2.63E-06 & \\
\hline U-240 & 2.13E-09 & $2.47 E-13$ & \\
\hline Y-90 & $3.82 E+03$ & 4.44E-01 & \\
\hline Zr-93 & 4.43E-02 & 5.15E-06 & \\
\hline TOTAL & $8.61 E+03$ & 1.00E+00 & \\
\hline
\end{tabular}


WSRC-TR-2005-00157

Revision 0

\section{APPENDIX B. ACTIVITIES OF DRIED SLUDGE IN YEAR $2115(\mu \mathrm{Ci} / \mathrm{g})$}


WSRC-TR-2005-00157

Revision 0

\begin{tabular}{|c|c|c|c|}
\hline Nuclide & $\begin{array}{l}\text { Y } 2115 \\
\mu \mathrm{Ci} / \mathrm{g}\end{array}$ & $\begin{array}{c}\text { Fraction of } \\
\text { Activity }\end{array}$ & Reportable \\
\hline Ac-225 & $1.61 \mathrm{E}-04$ & $1.76 \mathrm{E}-07$ & \\
\hline Ac-227 & 1.23E-06 & 1.34E-09 & \\
\hline Ac-228 & 3.01E-05 & $3.28 \mathrm{E}-08$ & \\
\hline Am-241 & $1.71 \mathrm{E}+01$ & 1.86E-02 & Yes \\
\hline Am-242 & 5.38E-02 & 5.86E-05 & \\
\hline$A m-242 m$ & $5.41 \mathrm{E}-02$ & 5.89E-05 & \\
\hline Am-243 & $1.53 E+00$ & $1.67 \mathrm{E}-03$ & Yes \\
\hline At-217 & $1.61 \mathrm{E}-04$ & 1.76E-07 & \\
\hline At-218 & $1.51 \mathrm{E}-10$ & 1.64E-13 & \\
\hline Ba-137m & $2.35 E+01$ & 2.56E-02 & \\
\hline $\mathrm{Bi}-210$ & $4.35 \mathrm{E}-07$ & $4.74 \mathrm{E}-10$ & \\
\hline $\mathrm{Bi}-211$ & $1.22 \mathrm{E}-06$ & 1.33E-09 & \\
\hline $\mathrm{Bi}-212$ & 3.01E-05 & 3.28E-08 & \\
\hline $\mathrm{Bi}-213$ & $1.61 \mathrm{E}-04$ & 1.76E-07 & \\
\hline $\mathrm{Bi}-214$ & $7.54 \mathrm{E}-07$ & $8.22 \mathrm{E}-10$ & \\
\hline Cf-249 & $2.28 \mathrm{E}-02$ & $2.48 \mathrm{E}-05$ & \\
\hline Cf-250 & 2.19E-05 & $2.39 \mathrm{E}-08$ & \\
\hline Cf-251 & $2.06 \mathrm{E}-02$ & 2.24E-05 & \\
\hline $\mathrm{Cm}-242$ & 4.46E-02 & 4.86E-05 & \\
\hline $\mathrm{Cm}-243$ & 1.76E-02 & 1.91E-05 & \\
\hline $\mathrm{Cm}-244$ & $1.04 \mathrm{E}+00$ & 1.13E-03 & Yes \\
\hline $\mathrm{Cm}-245$ & 1.10E-02 & 1.20E-05 & \\
\hline $\mathrm{Cm}-246$ & $1.60 \mathrm{E}-02$ & 1.74E-05 & \\
\hline $\mathrm{Cm}-247$ & $2.65 \mathrm{E}-02$ & $2.89 \mathrm{E}-05$ & \\
\hline $\mathrm{Cm}-248$ & $2.77 \mathrm{E}-02$ & 3.02E-05 & \\
\hline Co-60 & 8.46E-07 & 9.22E-10 & \\
\hline Cs-135 & $1.34 \mathrm{E}-03$ & 1.46E-06 & \\
\hline Cs-137 & $2.48 \mathrm{E}+01$ & 2.70E-02 & Yes \\
\hline Eu-154 & 1.33E-03 & 1.45E-06 & \\
\hline Eu-155 & 4.47E-07 & $4.87 \mathrm{E}-10$ & \\
\hline Fr-221 & $1.61 \mathrm{E}-04$ & 1.76E-07 & \\
\hline $\mathrm{Fr}-223$ & 1.69E-08 & $1.84 \mathrm{E}-11$ & \\
\hline I-129 & $4.35 \mathrm{E}-04$ & 4.74E-07 & \\
\hline $\mathrm{Nb}-93 \mathrm{~m}$ & 4.41E-02 & 4.81E-05 & \\
\hline $\mathrm{Ni}-59$ & $6.62 \mathrm{E}-01$ & 7.22E-04 & Yes \\
\hline $\mathrm{Ni}-63$ & $2.45 \mathrm{E}+01$ & 2.66E-02 & Yes \\
\hline Np-237 & 3.37E-02 & 3.67E-05 & \\
\hline Np-238 & $2.57 \mathrm{E}-04$ & 2.80E-07 & \\
\hline Np-239 & $1.53 E+00$ & 1.67E-03 & \\
\hline $\mathrm{Np}-240 \mathrm{~m}$ & 2.34E-08 & $2.55 \mathrm{E}-11$ & \\
\hline Pa-231 & $1.70 \mathrm{E}-06$ & 1.85E-09 & \\
\hline $\mathrm{Pa}-233$ & 3.37E-02 & 3.67E-05 & \\
\hline $\mathrm{Pa}-234$ & 7.45E-05 & 8.12E-08 & \\
\hline $\mathrm{Pa}-234 \mathrm{~m}$ & $2.26 \mathrm{E}-02$ & $2.46 \mathrm{E}-05$ & \\
\hline Pb-209 & $1.61 \mathrm{E}-04$ & 1.76E-07 & \\
\hline $\mathrm{Pb}-210$ & 4.35E-07 & $4.74 \mathrm{E}-10$ & \\
\hline $\mathrm{Pb}-211$ & 1.22E-06 & 1.33E-09 & \\
\hline $\mathrm{Pb}-212$ & $3.01 \mathrm{E}-05$ & $3.28 \mathrm{E}-08$ & \\
\hline $\mathrm{Pb}-214$ & 7.54E-07 & $8.22 \mathrm{E}-10$ & \\
\hline $\mathrm{Pd}-107$ & $6.89 \mathrm{E}-04$ & 7.51E-07 & \\
\hline Pm-147 & $2.87 \mathrm{E}-10$ & $3.12 \mathrm{E}-13$ & \\
\hline Po-210 & $4.29 \mathrm{E}-07$ & $4.68 \mathrm{E}-10$ & \\
\hline Po-211 & 3.43E-09 & $3.74 \mathrm{E}-12$ & \\
\hline Po-212 & 1.93E-05 & 2.10E-08 & \\
\hline Po-213 & $1.58 \mathrm{E}-04$ & 1.72E-07 & \\
\hline Po-214 & 7.54E-07 & $8.22 \mathrm{E}-10$ & \\
\hline Po-215 & 1.22E-06 & 1.33E-09 & \\
\hline Po-216 & $3.01 \mathrm{E}-05$ & $3.28 \mathrm{E}-08$ & \\
\hline
\end{tabular}

\begin{tabular}{|c|c|c|c|}
\hline Nuclide & $\begin{array}{l}\text { Y } 2115 \\
\mu \mathrm{Ci} / \mathrm{g}\end{array}$ & $\begin{array}{c}\text { Fraction of } \\
\text { Activity }\end{array}$ & Reportable \\
\hline Po-218 & $7.54 \mathrm{E}-07$ & $8.22 \mathrm{E}-10$ & \\
\hline Pu-238 & $1.09 \mathrm{E}+01$ & 1.19E-02 & Yes \\
\hline Pu-239 & $1.37 \mathrm{E}+01$ & 1.49E-02 & Yes \\
\hline Pu-240 & $4.93 E+00$ & 5.38E-03 & Yes \\
\hline Pu-241 & 2.83E-01 & $3.08 \mathrm{E}-04$ & Yes \\
\hline Pu-242 & $5.46 \mathrm{E}-03$ & 5.95E-06 & \\
\hline Pu-243 & $2.65 \mathrm{E}-02$ & 2.89E-05 & \\
\hline Pu-244 & $2.35 \mathrm{E}-08$ & $2.56 \mathrm{E}-11$ & \\
\hline Ra-223 & 1.22E-06 & 1.33E-09 & \\
\hline Ra-224 & 3.01E-05 & 3.28E-08 & \\
\hline Ra-225 & $1.61 \mathrm{E}-04$ & 1.76E-07 & \\
\hline Ra-226 & $7.55 \mathrm{E}-07$ & 8.22E-10 & \\
\hline Ra-228 & 3.01E-05 & 3.28E-08 & \\
\hline Rn-219 & $1.22 \mathrm{E}-06$ & 1.33E-09 & \\
\hline Rn-220 & 3.01E-05 & $3.28 \mathrm{E}-08$ & \\
\hline Rn-222 & 7.54E-07 & $8.22 \mathrm{E}-10$ & \\
\hline Sb-125 & $9.22 \mathrm{E}-14$ & 1.00E-16 & \\
\hline Sb-126 & 1.99E-03 & 2.16E-06 & \\
\hline Sb-126m & 1.42E-02 & 1.55E-05 & \\
\hline Se-79 & 1.97E-02 & 2.14E-05 & \\
\hline Sm-147 & 2.97E-08 & 3.24E-11 & \\
\hline Sm-151 & $8.40 \mathrm{E}+01$ & $9.15 \mathrm{E}-02$ & Yes \\
\hline Sn-121 & 4.54E-01 & $4.95 \mathrm{E}-04$ & \\
\hline Sn-121m & $5.85 \mathrm{E}-01$ & 6.37E-04 & Yes \\
\hline Sn-126 & 1.42E-02 & 1.55E-05 & \\
\hline Sr-90 & $3.54 \mathrm{E}+02$ & 3.85E-01 & Yes \\
\hline Tc-99 & 1.96E-01 & 2.13E-04 & Yes \\
\hline Te-125m & $2.23 \mathrm{E}-14$ & 2.43E-17 & \\
\hline Th-227 & $1.21 \mathrm{E}-06$ & 1.32E-09 & \\
\hline Th-228 & 3.01E-05 & 3.28E-08 & \\
\hline Th-229 & 1.61E-04 & 1.76E-07 & \\
\hline Th-230 & 3.30E-05 & 3.60E-08 & \\
\hline Th-231 & 7.30E-04 & 7.96E-07 & \\
\hline Th-232 & 3.01E-05 & 3.28E-08 & \\
\hline Th-234 & $2.26 \mathrm{E}-02$ & 2.46E-05 & \\
\hline TI-207 & $1.22 \mathrm{E}-06$ & 1.33E-09 & \\
\hline TI-208 & 1.08E-05 & 1.18E-08 & \\
\hline TI-209 & $3.48 \mathrm{E}-06$ & 3.79E-09 & \\
\hline U-233 & 1.56E-02 & 1.70E-05 & \\
\hline U-234 & 3.57E-02 & 3.89E-05 & \\
\hline U-235 & 7.30E-04 & 7.96E-07 & \\
\hline U-236 & 8.62E-04 & 9.39E-07 & \\
\hline U-237 & 6.94E-06 & 7.56E-09 & \\
\hline U-238 & $2.26 \mathrm{E}-02$ & 2.46E-05 & \\
\hline U-240 & 2.34E-08 & $2.55 \mathrm{E}-11$ & \\
\hline Y-90 & $3.54 \mathrm{E}+02$ & 3.86E-01 & \\
\hline Zr-93 & 4.43E-02 & 4.83E-05 & \\
\hline TOTAL & $9.18 \mathrm{E}+02$ & $1.00 \mathrm{E}+00$ & \\
\hline
\end{tabular}


WSRC-TR-2005-00157

Revision 0

\section{APPENDIX C. ACTIVITIES OF DRIED SLUDGE IN YEAR $2215(\mu \mathrm{Ci} / \mathrm{g})$}


WSRC-TR-2005-00157

Revision 0

\begin{tabular}{|c|c|c|c|}
\hline Nuclide & $\begin{array}{l}\text { Y } 2215 \\
\mu \mathrm{Ci} / \mathrm{g}\end{array}$ & $\begin{array}{c}\text { Fraction of } \\
\text { Activity }\end{array}$ & Reportable \\
\hline Ac-225 & $3.06 \mathrm{E}-04$ & 1.87E-06 & \\
\hline Ac-227 & $2.75 \mathrm{E}-06$ & 1.68E-08 & \\
\hline Ac-228 & $3.01 \mathrm{E}-05$ & $1.84 \mathrm{E}-07$ & \\
\hline Am-241 & $1.45 \mathrm{E}+01$ & 8.88E-02 & Yes \\
\hline Am-242 & $3.41 \mathrm{E}-02$ & $2.08 \mathrm{E}-04$ & \\
\hline Am-242m & 3.43E-02 & $2.09 \mathrm{E}-04$ & Yes \\
\hline Am-243 & $1.52 \mathrm{E}+00$ & $9.28 \mathrm{E}-03$ & Yes \\
\hline At-217 & $3.06 \mathrm{E}-04$ & $1.87 \mathrm{E}-06$ & \\
\hline At-218 & $5.65 \mathrm{E}-10$ & $3.45 \mathrm{E}-12$ & \\
\hline $\mathrm{Ba}-137 \mathrm{~m}$ & $2.33 E+00$ & 1.42E-02 & \\
\hline Bi-210 & $2.08 \mathrm{E}-06$ & $1.27 \mathrm{E}-08$ & \\
\hline $\mathrm{Bi}-211$ & $2.75 \mathrm{E}-06$ & 1.68E-08 & \\
\hline $\mathrm{Bi}-212$ & $3.01 \mathrm{E}-05$ & 1.84E-07 & \\
\hline $\mathrm{Bi}-213$ & 3.06E-04 & 1.87E-06 & \\
\hline $\mathrm{Bi}-214$ & 2.82E-06 & 1.72E-08 & \\
\hline Cf-249 & $1.87 \mathrm{E}-02$ & 1.14E-04 & Yes \\
\hline Cf-250 & $1.10 \mathrm{E}-07$ & $6.69 \mathrm{E}-10$ & \\
\hline Cf-251 & 1.90E-02 & 1.16E-04 & Yes \\
\hline $\mathrm{Cm}-242$ & $2.83 \mathrm{E}-02$ & $1.73 \mathrm{E}-04$ & \\
\hline $\mathrm{Cm}-243$ & $1.54 \mathrm{E}-03$ & 9.42E-06 & \\
\hline $\mathrm{Cm}-244$ & $2.26 \mathrm{E}-02$ & $1.38 \mathrm{E}-04$ & Yes \\
\hline $\mathrm{Cm}-245$ & $1.11 \mathrm{E}-02$ & $6.78 \mathrm{E}-05$ & \\
\hline $\mathrm{Cm}-246$ & 1.57E-02 & $9.60 \mathrm{E}-05$ & \\
\hline $\mathrm{Cm}-247$ & $2.65 \mathrm{E}-02$ & 1.62E-04 & Yes \\
\hline Cm-248 & 2.77E-02 & 1.69E-04 & Yes \\
\hline Co-60 & $1.65 \mathrm{E}-12$ & $1.01 \mathrm{E}-14$ & \\
\hline Cs-135 & $1.34 \mathrm{E}-03$ & 8.18E-06 & \\
\hline Cs-137 & $2.46 \mathrm{E}+00$ & 1.50E-02 & Yes \\
\hline Eu-154 & 5.07E-07 & 3.09E-09 & \\
\hline Eu-155 & $3.82 \mathrm{E}-13$ & $2.33 \mathrm{E}-15$ & \\
\hline Fr-221 & 3.06E-04 & 1.87E-06 & \\
\hline Fr-223 & 3.80E-08 & 2.32E-10 & \\
\hline I-129 & $4.35 \mathrm{E}-04$ & $2.65 \mathrm{E}-06$ & \\
\hline $\mathrm{Nb}-93 \mathrm{~m}$ & 4.43E-02 & 2.70E-04 & Yes \\
\hline $\mathrm{Ni}-59$ & $6.62 \mathrm{E}-01$ & 4.04E-03 & Yes \\
\hline $\mathrm{Ni}-63$ & $1.19 \mathrm{E}+01$ & $7.25 \mathrm{E}-02$ & Yes \\
\hline Np-237 & 3.42E-02 & $2.08 \mathrm{E}-04$ & Yes \\
\hline Np-238 & 1.63E-04 & 9.96E-07 & \\
\hline Np-239 & $1.52 \mathrm{E}+00$ & $9.28 \mathrm{E}-03$ & \\
\hline $\mathrm{Np}-240 \mathrm{~m}$ & 4.47E-08 & 2.73E-10 & \\
\hline Pa-231 & $3.24 \mathrm{E}-06$ & 1.98E-08 & \\
\hline $\mathrm{Pa}-233$ & 3.42E-02 & $2.08 \mathrm{E}-04$ & \\
\hline $\mathrm{Pa}-234$ & 7.45E-05 & 4.55E-07 & \\
\hline $\mathrm{Pa}-234 \mathrm{~m}$ & $2.26 \mathrm{E}-02$ & 1.38E-04 & \\
\hline Pb-209 & 3.06E-04 & 1.87E-06 & \\
\hline $\mathrm{Pb}-210$ & $2.08 \mathrm{E}-06$ & 1.27E-08 & \\
\hline $\mathrm{Pb}-211$ & $2.75 \mathrm{E}-06$ & 1.68E-08 & \\
\hline $\mathrm{Pb}-212$ & $3.01 \mathrm{E}-05$ & 1.84E-07 & \\
\hline $\mathrm{Pb}-214$ & $2.82 \mathrm{E}-06$ & 1.72E-08 & \\
\hline Pd-107 & $6.89 \mathrm{E}-04$ & 4.20E-06 & \\
\hline Pm-147 & $9.61 \mathrm{E}-22$ & $5.87 \mathrm{E}-24$ & \\
\hline Po-210 & 2.07E-06 & 1.26E-08 & \\
\hline Po-211 & 7.71E-09 & 4.70E-11 & \\
\hline Po-212 & 1.93E-05 & 1.18E-07 & \\
\hline Po-213 & 3.00E-04 & 1.83E-06 & \\
\hline Po-214 & 2.82E-06 & 1.72E-08 & \\
\hline Po-215 & $2.75 \mathrm{E}-06$ & 1.68E-08 & \\
\hline Po-216 & $3.01 \mathrm{E}-05$ & 1.84E-07 & \\
\hline
\end{tabular}

\begin{tabular}{|c|c|c|c|}
\hline Nuclide & $\begin{array}{l}\text { Y } 2215 \\
\mu \mathrm{Ci} / \mathrm{g}\end{array}$ & $\begin{array}{c}\text { Fraction of } \\
\text { Activity }\end{array}$ & Reportable \\
\hline Po-218 & $2.82 \mathrm{E}-06$ & $1.72 \mathrm{E}-08$ & \\
\hline Pu-238 & $4.96 \mathrm{E}+00$ & 3.03E-02 & Yes \\
\hline Pu-239 & $1.36 \mathrm{E}+01$ & 8.32E-02 & Yes \\
\hline Pu-240 & $4.88 \mathrm{E}+00$ & $2.98 \mathrm{E}-02$ & Yes \\
\hline Pu-241 & 1.33E-02 & 8.12E-05 & \\
\hline Pu-242 & $5.47 \mathrm{E}-03$ & 3.34E-05 & \\
\hline Pu-243 & $2.65 \mathrm{E}-02$ & $1.62 \mathrm{E}-04$ & \\
\hline Pu-244 & 4.48E-08 & $2.73 \mathrm{E}-10$ & \\
\hline Ra-223 & 2.75E-06 & 1.68E-08 & \\
\hline Ra-224 & 3.01E-05 & $1.84 \mathrm{E}-07$ & \\
\hline Ra-225 & 3.06E-04 & 1.87E-06 & \\
\hline Ra-226 & $2.83 \mathrm{E}-06$ & $1.72 \mathrm{E}-08$ & \\
\hline Ra-228 & 3.01E-05 & $1.84 \mathrm{E}-07$ & \\
\hline Rn-219 & $2.75 \mathrm{E}-06$ & $1.68 \mathrm{E}-08$ & \\
\hline Rn-220 & 3.01E-05 & $1.84 \mathrm{E}-07$ & \\
\hline Rn-222 & 2.82E-06 & $1.72 \mathrm{E}-08$ & \\
\hline Sb-125 & $1.25 \mathrm{E}-24$ & $7.64 \mathrm{E}-27$ & \\
\hline Sb-126 & $1.99 \mathrm{E}-03$ & $1.21 \mathrm{E}-05$ & \\
\hline Sb-126m & 1.42E-02 & 8.65E-05 & \\
\hline Se-79 & 1.97E-02 & $1.20 \mathrm{E}-04$ & Yes \\
\hline Sm-147 & $2.97 \mathrm{E}-08$ & $1.81 \mathrm{E}-10$ & \\
\hline Sm-151 & $3.89 \mathrm{E}+01$ & 2.37E-01 & Yes \\
\hline Sn-121 & 1.29E-01 & $7.86 \mathrm{E}-04$ & \\
\hline $\mathrm{Sn}-121 \mathrm{~m}$ & $1.66 \mathrm{E}-01$ & $1.01 \mathrm{E}-03$ & Yes \\
\hline Sn-126 & 1.42E-02 & $8.65 E-05$ & \\
\hline Sr-90 & $3.27 \mathrm{E}+01$ & $2.00 \mathrm{E}-01$ & Yes \\
\hline TC-99 & 1.96E-01 & $1.20 \mathrm{E}-03$ & Yes \\
\hline Te-125m & 3.03E-25 & $1.85 \mathrm{E}-27$ & \\
\hline Th-227 & $2.72 \mathrm{E}-06$ & 1.66E-08 & \\
\hline Th-228 & $3.01 \mathrm{E}-05$ & $1.84 \mathrm{E}-07$ & \\
\hline Th-229 & 3.06E-04 & $1.87 \mathrm{E}-06$ & \\
\hline Th-230 & $6.62 \mathrm{E}-05$ & 4.04E-07 & \\
\hline Th-231 & 7.32E-04 & 4.47E-06 & \\
\hline Th-232 & $3.01 \mathrm{E}-05$ & 1.84E-07 & \\
\hline Th-234 & $2.26 \mathrm{E}-02$ & $1.38 \mathrm{E}-04$ & \\
\hline TI-207 & $2.74 \mathrm{E}-06$ & $1.68 \mathrm{E}-08$ & \\
\hline TI-208 & 1.08E-05 & $6.60 \mathrm{E}-08$ & \\
\hline TI-209 & $6.62 \mathrm{E}-06$ & $4.04 \mathrm{E}-08$ & \\
\hline U-233 & $1.56 \mathrm{E}-02$ & $9.53 \mathrm{E}-05$ & \\
\hline U-234 & 3.78E-02 & $2.31 \mathrm{E}-04$ & Yes \\
\hline U-235 & 7.32E-04 & 4.47E-06 & \\
\hline U-236 & 8.77E-04 & $5.35 \mathrm{E}-06$ & \\
\hline U-237 & 3.26E-07 & 1.99E-09 & \\
\hline U-238 & $2.26 \mathrm{E}-02$ & $1.38 \mathrm{E}-04$ & Yes \\
\hline U-240 & 4.47E-08 & $2.73 \mathrm{E}-10$ & \\
\hline Y-90 & $3.27 \mathrm{E}+01$ & $2.00 \mathrm{E}-01$ & \\
\hline Zr-93 & 4.43E-02 & $2.70 \mathrm{E}-04$ & Yes \\
\hline TOTAL & $1.64 \mathrm{E}+02$ & $1.00 \mathrm{E}+00$ & \\
\hline
\end{tabular}


WSRC-TR-2005-00157

Revision 0

\section{APPENDIX D. ACTIVITIES OF DRIED SLUDGE IN YEAR $2315(\mu \mathrm{Ci} / \mathrm{g})$}


WSRC-TR-2005-00157

Revision 0

\begin{tabular}{|c|c|c|c|}
\hline Nuclide & $\begin{array}{l}\text { Y } 2315 \\
\mu \mathrm{Ci} / \mathrm{g}\end{array}$ & $\begin{array}{c}\text { Fraction of } \\
\text { Activity }\end{array}$ & Reportable \\
\hline Ac-225 & $4.50 \mathrm{E}-04$ & 6.63E-06 & \\
\hline Ac-227 & 4.30E-06 & 6.33E-08 & \\
\hline Ac-228 & 3.01E-05 & 4.43E-07 & \\
\hline Am-241 & $1.24 \mathrm{E}+01$ & 1.83E-01 & Yes \\
\hline Am-242 & $2.16 \mathrm{E}-02$ & 3.18E-04 & \\
\hline$A m-242 m$ & 2.17E-02 & $3.20 \mathrm{E}-04$ & Yes \\
\hline Am-243 & $1.51 E+00$ & 2.22E-02 & Yes \\
\hline At-217 & 4.50E-04 & $6.63 \mathrm{E}-06$ & \\
\hline At-218 & $1.25 \mathrm{E}-09$ & 1.84E-11 & \\
\hline Ba-137m & $2.31 \mathrm{E}-01$ & $3.40 \mathrm{E}-03$ & \\
\hline Bi-210 & 5.07E-06 & 7.46E-08 & \\
\hline Bi-211 & 4.29E-06 & 6.32E-08 & \\
\hline $\mathrm{Bi}-212$ & 3.01E-05 & 4.43E-07 & \\
\hline $\mathrm{Bi}-213$ & $4.50 \mathrm{E}-04$ & 6.63E-06 & \\
\hline $\mathrm{Bi}-214$ & $6.25 E-06$ & $9.20 \mathrm{E}-08$ & \\
\hline Cf-249 & 1.53E-02 & 2.26E-04 & Yes \\
\hline Cf-250 & 5.48E-10 & 8.06E-12 & \\
\hline Cf-251 & $1.76 \mathrm{E}-02$ & 2.60E-04 & Yes \\
\hline $\mathrm{Cm}-242$ & $1.79 \mathrm{E}-02$ & 2.64E-04 & \\
\hline $\mathrm{Cm}-243$ & $1.36 \mathrm{E}-04$ & 2.00E-06 & \\
\hline $\mathrm{Cm}-244$ & 4.92E-04 & $7.25 E-06$ & \\
\hline $\mathrm{Cm}-245$ & 1.12E-02 & 1.64E-04 & Yes \\
\hline $\mathrm{Cm}-246$ & $1.55 \mathrm{E}-02$ & 2.28E-04 & Yes \\
\hline $\mathrm{Cm}-247$ & $2.65 \mathrm{E}-02$ & $3.90 \mathrm{E}-04$ & Yes \\
\hline $\mathrm{Cm}-248$ & $2.77 \mathrm{E}-02$ & 4.08E-04 & Yes \\
\hline Co-60 & $3.20 \mathrm{E}-18$ & $4.72 \mathrm{E}-20$ & \\
\hline Cs-135 & $1.34 \mathrm{E}-03$ & 1.97E-05 & \\
\hline Cs-137 & 2.44E-01 & 3.60E-03 & Yes \\
\hline Eu-154 & $1.92 \mathrm{E}-10$ & $2.83 \mathrm{E}-12$ & \\
\hline Eu-155 & $3.25 E-19$ & $4.79 E-21$ & \\
\hline Fr-221 & 4.50E-04 & 6.63E-06 & \\
\hline Fr-223 & 5.93E-08 & 8.73E-10 & \\
\hline $\mathrm{I}-129$ & 4.35E-04 & $6.41 \mathrm{E}-06$ & \\
\hline $\mathrm{Nb}-93 \mathrm{~m}$ & 4.43E-02 & $6.52 \mathrm{E}-04$ & Yes \\
\hline $\mathrm{Ni}-59$ & 6.61E-01 & 9.74E-03 & Yes \\
\hline $\mathrm{Ni}-63$ & $5.77 \mathrm{E}+00$ & 8.50E-02 & Yes \\
\hline Np-237 & $3.46 \mathrm{E}-02$ & 5.09E-04 & Yes \\
\hline Np-238 & 1.03E-04 & 1.52E-06 & \\
\hline Np-239 & $1.51 E+00$ & $2.22 \mathrm{E}-02$ & \\
\hline $\mathrm{Np}-240 \mathrm{~m}$ & 6.60E-08 & $9.72 \mathrm{E}-10$ & \\
\hline $\mathrm{Pa}-231$ & $4.78 \mathrm{E}-06$ & 7.04E-08 & \\
\hline $\mathrm{Pa}-233$ & $3.46 \mathrm{E}-02$ & 5.09E-04 & \\
\hline $\mathrm{Pa}-234$ & $7.45 \mathrm{E}-05$ & 1.10E-06 & \\
\hline $\mathrm{Pa}-234 \mathrm{~m}$ & $2.26 \mathrm{E}-02$ & 3.32E-04 & \\
\hline $\mathrm{Pb}-209$ & $4.50 \mathrm{E}-04$ & 6.63E-06 & \\
\hline $\mathrm{Pb}-210$ & 5.07E-06 & 7.46E-08 & \\
\hline $\mathrm{Pb}-211$ & $4.29 \mathrm{E}-06$ & 6.32E-08 & \\
\hline $\mathrm{Pb}-212$ & 3.01E-05 & 4.43E-07 & \\
\hline $\mathrm{Pb}-214$ & $6.24 \mathrm{E}-06$ & $9.20 \mathrm{E}-08$ & \\
\hline Pd-107 & 6.89E-04 & 1.01E-05 & \\
\hline $\mathrm{Pm}-147$ & $3.22 \mathrm{E}-33$ & 4.75E-35 & \\
\hline Po-210 & 5.05E-06 & 7.43E-08 & \\
\hline Po-211 & $1.20 \mathrm{E}-08$ & 1.77E-10 & \\
\hline Po-212 & 1.93E-05 & 2.84E-07 & \\
\hline Po-213 & 4.41E-04 & $6.49 \mathrm{E}-06$ & \\
\hline Po-214 & $6.24 \mathrm{E}-06$ & $9.20 \mathrm{E}-08$ & \\
\hline Po-215 & $4.29 \mathrm{E}-06$ & 6.32E-08 & \\
\hline Po-216 & 3.01E-05 & 4.43E-07 & \\
\hline
\end{tabular}

\begin{tabular}{|c|c|c|c|}
\hline Nuclide & $\begin{array}{l}\text { Y } 2315 \\
\mu \mathrm{Ci} / \mathrm{g}\end{array}$ & $\begin{array}{c}\text { Fraction of } \\
\text { Activity }\end{array}$ & Reportable \\
\hline Po-218 & $6.25 E-06$ & 9.20E-08 & \\
\hline Pu-238 & $2.26 \mathrm{E}+00$ & 3.34E-02 & Yes \\
\hline Pu-239 & $1.36 \mathrm{E}+01$ & 2.00E-01 & Yes \\
\hline Pu-240 & $4.83 E+00$ & 7.12E-02 & Yes \\
\hline Pu-241 & 1.12E-02 & 1.64E-04 & Yes \\
\hline Pu-242 & 5.47E-03 & 8.06E-05 & \\
\hline Pu-243 & 2.65E-02 & 3.90E-04 & \\
\hline Pu-244 & 6.61E-08 & 9.73E-10 & \\
\hline Ra-223 & 4.29E-06 & 6.32E-08 & \\
\hline Ra-224 & 3.01E-05 & 4.43E-07 & \\
\hline $\mathrm{Ra}-225$ & 4.50E-04 & 6.63E-06 & \\
\hline $\mathrm{Ra}-226$ & $6.25 E-06$ & 9.20E-08 & \\
\hline $\mathrm{Ra}-228$ & 3.01E-05 & 4.43E-07 & \\
\hline Rn-219 & 4.29E-06 & $6.32 \mathrm{E}-08$ & \\
\hline $\mathrm{Rn}-220$ & 3.01E-05 & 4.43E-07 & \\
\hline Rn-222 & $6.25 E-06$ & $9.20 \mathrm{E}-08$ & \\
\hline Sb-125 & 1.70E-35 & $2.50 E-37$ & \\
\hline Sb-126 & 1.98E-03 & 2.92E-05 & \\
\hline Sb-126m & 1.42E-02 & 2.09E-04 & \\
\hline Se-79 & $1.96 \mathrm{E}-02$ & 2.89E-04 & Yes \\
\hline Sm-147 & 2.97E-08 & 4.37E-10 & \\
\hline Sm-151 & $1.80 E+01$ & 2.65E-01 & Yes \\
\hline Sn-121 & 3.65E-02 & 5.38E-04 & \\
\hline Sn-121m & 4.70E-02 & 6.93E-04 & Yes \\
\hline Sn-126 & 1.42E-02 & 2.09E-04 & Yes \\
\hline Sr-90 & $3.03 E+00$ & 4.46E-02 & Yes \\
\hline Tc-99 & 1.96E-01 & 2.88E-03 & Yes \\
\hline Te-125m & 4.11E-36 & $6.05 E-38$ & \\
\hline Th-227 & 4.23E-06 & $6.24 \mathrm{E}-08$ & \\
\hline Th-228 & 3.01E-05 & 4.43E-07 & \\
\hline Th-229 & 4.50E-04 & 6.63E-06 & \\
\hline Th-230 & 1.01E-04 & $1.48 \mathrm{E}-06$ & \\
\hline Th-231 & 7.33E-04 & $1.08 \mathrm{E}-05$ & \\
\hline Th-232 & 3.01E-05 & 4.43E-07 & \\
\hline Th-234 & 2.26E-02 & 3.33E-04 & \\
\hline TI-207 & 4.28E-06 & 6.31E-08 & \\
\hline TI-208 & 1.08E-05 & $1.59 \mathrm{E}-07$ & \\
\hline TI-209 & 9.73E-06 & $1.43 \mathrm{E}-07$ & \\
\hline U-233 & 1.56E-02 & 2.30E-04 & Yes \\
\hline U-234 & 3.88E-02 & 5.71E-04 & Yes \\
\hline U-235 & 7.33E-04 & 1.08E-05 & \\
\hline U-236 & 8.91E-04 & $1.31 \mathrm{E}-05$ & \\
\hline U-237 & 2.74E-07 & 4.03E-09 & \\
\hline U-238 & 2.26E-02 & 3.33E-04 & Yes \\
\hline$U-240$ & 6.60E-08 & $9.72 \mathrm{E}-10$ & \\
\hline Y-90 & $3.03 E+00$ & 4.46E-02 & \\
\hline Zr-93 & 4.43E-02 & $6.52 \mathrm{E}-04$ & Yes \\
\hline TOTAL & $6.79 E+01$ & $1.00 \mathrm{E}+00$ & \\
\hline
\end{tabular}


WSRC-TR-2005-00157

Revision 0

\section{APPENDIX E. ACTIVITIES OF DRIED SLUDGE IN YEAR $2415(\mu \mathrm{Ci} / \mathrm{g})$}


WSRC-TR-2005-00157

Revision 0

\begin{tabular}{|c|c|c|c|}
\hline Nuclide & $\begin{array}{l}\text { Y } 2415 \\
\mu \mathrm{Ci} / \mathrm{g}\end{array}$ & $\begin{array}{c}\text { Fraction of } \\
\text { Activity }\end{array}$ & Reportable \\
\hline Ac-225 & $5.93 \mathrm{E}-04$ & $1.29 \mathrm{E}-05$ & \\
\hline Ac-227 & $5.84 \mathrm{E}-06$ & $1.27 \mathrm{E}-07$ & \\
\hline Ac-228 & $3.01 \mathrm{E}-05$ & $6.53 \mathrm{E}-07$ & \\
\hline Am-241 & $1.06 \mathrm{E}+01$ & $2.29 \mathrm{E}-01$ & Yes \\
\hline Am-242 & 1.37E-02 & $2.97 \mathrm{E}-04$ & \\
\hline Am-242m & 1.38E-02 & $2.99 \mathrm{E}-04$ & Yes \\
\hline Am-243 & $1.49 \mathrm{E}+00$ & 3.24E-02 & Yes \\
\hline At-217 & $5.93 \mathrm{E}-04$ & $1.29 \mathrm{E}-05$ & \\
\hline At-218 & 2.20E-09 & $4.77 \mathrm{E}-11$ & \\
\hline $\mathrm{Ba}-137 \mathrm{~m}$ & $2.29 \mathrm{E}-02$ & 4.97E-04 & \\
\hline Bi-210 & $9.39 \mathrm{E}-06$ & $2.04 \mathrm{E}-07$ & \\
\hline $\mathrm{Bi}-211$ & $5.83 \mathrm{E}-06$ & $1.27 \mathrm{E}-07$ & \\
\hline $\mathrm{Bi}-212$ & $3.01 \mathrm{E}-05$ & $6.53 \mathrm{E}-07$ & \\
\hline $\mathrm{Bi}-213$ & 5.93E-04 & 1.29E-05 & \\
\hline $\mathrm{Bi}-214$ & 1.10E-05 & $2.39 \mathrm{E}-07$ & \\
\hline Cf-249 & $1.26 \mathrm{E}-02$ & $2.73 \mathrm{E}-04$ & Yes \\
\hline Cf-250 & $2.74 \mathrm{E}-12$ & $5.94 \mathrm{E}-14$ & \\
\hline Cf-251 & 1.63E-02 & 3.54E-04 & Yes \\
\hline $\mathrm{Cm}-242$ & $1.14 \mathrm{E}-02$ & 2.47E-04 & \\
\hline $\mathrm{Cm}-243$ & 1.19E-05 & $2.59 \mathrm{E}-07$ & \\
\hline $\mathrm{Cm}-244$ & 1.07E-05 & 2.33E-07 & \\
\hline $\mathrm{Cm}-245$ & $1.12 \mathrm{E}-02$ & $2.43 \mathrm{E}-04$ & Yes \\
\hline $\mathrm{Cm}-246$ & 1.53E-02 & 3.32E-04 & Yes \\
\hline $\mathrm{Cm}-247$ & $2.65 \mathrm{E}-02$ & $5.75 \mathrm{E}-04$ & Yes \\
\hline $\mathrm{Cm}-248$ & 2.77E-02 & $6.01 \mathrm{E}-04$ & Yes \\
\hline Co-60 & $6.23 \mathrm{E}-24$ & $1.35 \mathrm{E}-25$ & \\
\hline Cs-135 & $1.34 \mathrm{E}-03$ & 2.91E-05 & \\
\hline Cs-137 & $2.42 \mathrm{E}-02$ & $5.26 \mathrm{E}-04$ & Yes \\
\hline Eu-154 & $7.30 \mathrm{E}-14$ & $1.58 \mathrm{E}-15$ & \\
\hline Eu-155 & $2.78 \mathrm{E}-25$ & $6.02 \mathrm{E}-27$ & \\
\hline Fr-221 & $5.93 \mathrm{E}-04$ & 1.29E-05 & \\
\hline Fr-223 & 8.05E-08 & 1.75E-09 & \\
\hline I-129 & $4.35 \mathrm{E}-04$ & $9.44 \mathrm{E}-06$ & \\
\hline $\mathrm{Nb}-93 \mathrm{~m}$ & 4.43E-02 & $9.61 \mathrm{E}-04$ & Yes \\
\hline $\mathrm{Ni}-59$ & $6.60 \mathrm{E}-01$ & 1.43E-02 & Yes \\
\hline $\mathrm{Ni}-63$ & $2.80 \mathrm{E}+00$ & $6.08 \mathrm{E}-02$ & Yes \\
\hline Np-237 & 3.50E-02 & 7.59E-04 & Yes \\
\hline Np-238 & $6.55 \mathrm{E}-05$ & 1.42E-06 & \\
\hline Np-239 & $1.49 E+00$ & $3.24 \mathrm{E}-02$ & \\
\hline $\mathrm{Np}-240 \mathrm{~m}$ & 8.73E-08 & 1.89E-09 & \\
\hline Pa-231 & $6.32 \mathrm{E}-06$ & 1.37E-07 & \\
\hline $\mathrm{Pa}-233$ & 3.50E-02 & $7.59 \mathrm{E}-04$ & \\
\hline $\mathrm{Pa}-234$ & 7.45E-05 & 1.62E-06 & \\
\hline $\mathrm{Pa}-234 \mathrm{~m}$ & $2.26 \mathrm{E}-02$ & 4.90E-04 & \\
\hline Pb-209 & 5.93E-04 & 1.29E-05 & \\
\hline $\mathrm{Pb}-210$ & $9.39 \mathrm{E}-06$ & $2.04 \mathrm{E}-07$ & \\
\hline $\mathrm{Pb}-211$ & 5.83E-06 & 1.27E-07 & \\
\hline $\mathrm{Pb}-212$ & $3.01 \mathrm{E}-05$ & $6.53 \mathrm{E}-07$ & \\
\hline $\mathrm{Pb}-214$ & 1.10E-05 & $2.39 \mathrm{E}-07$ & \\
\hline Pd-107 & $6.89 \mathrm{E}-04$ & 1.50E-05 & \\
\hline Pm-147 & $1.08 \mathrm{E}-44$ & $2.34 \mathrm{E}-46$ & \\
\hline Po-210 & $9.36 \mathrm{E}-06$ & 2.03E-07 & \\
\hline Po-211 & 1.63E-08 & $3.55 \mathrm{E}-10$ & \\
\hline Po-212 & 1.93E-05 & 4.19E-07 & \\
\hline Po-213 & $5.80 \mathrm{E}-04$ & 1.26E-05 & \\
\hline Po-214 & 1.10E-05 & 2.39E-07 & \\
\hline Po-215 & $5.83 \mathrm{E}-06$ & $1.27 \mathrm{E}-07$ & \\
\hline Po-216 & $3.01 \mathrm{E}-05$ & $6.53 \mathrm{E}-07$ & \\
\hline
\end{tabular}

\begin{tabular}{|c|c|c|c|}
\hline Nuclide & $\begin{array}{l}\text { Y } 2415 \\
\mu \mathrm{Ci} / \mathrm{g}\end{array}$ & $\begin{array}{c}\text { Fraction of } \\
\text { Activity } \\
\end{array}$ & Reportable \\
\hline Po-218 & 1.10E-05 & $2.39 \mathrm{E}-07$ & \\
\hline Pu-238 & $1.04 \mathrm{E}+00$ & $2.25 \mathrm{E}-02$ & Yes \\
\hline Pu-239 & $1.36 \mathrm{E}+01$ & 2.94E-01 & Yes \\
\hline Pu-240 & $4.78 \mathrm{E}+00$ & 1.04E-01 & Yes \\
\hline Pu-241 & 1.12E-02 & $2.43 \mathrm{E}-04$ & Yes \\
\hline Pu-242 & 5.47E-03 & 1.19E-04 & Yes \\
\hline Pu-243 & $2.65 \mathrm{E}-02$ & $5.75 \mathrm{E}-04$ & \\
\hline Pu-244 & 8.74E-08 & 1.90E-09 & \\
\hline Ra-223 & 5.83E-06 & 1.27E-07 & \\
\hline Ra-224 & 3.01E-05 & $6.53 \mathrm{E}-07$ & \\
\hline Ra-225 & 5.93E-04 & $1.29 \mathrm{E}-05$ & \\
\hline Ra-226 & 1.10E-05 & $2.39 \mathrm{E}-07$ & \\
\hline Ra-228 & 3.01E-05 & $6.53 E-07$ & \\
\hline Rn-219 & 5.83E-06 & 1.27E-07 & \\
\hline Rn-220 & 3.01E-05 & $6.53 E-07$ & \\
\hline Rn-222 & 1.10E-05 & 2.39E-07 & \\
\hline Sb-125 & $2.31 \mathrm{E}-46$ & $5.00 E-48$ & \\
\hline Sb-126 & 1.98E-03 & 4.30E-05 & \\
\hline Sb-126m & 1.42E-02 & $3.07 \mathrm{E}-04$ & \\
\hline Se-79 & 1.96E-02 & $4.26 \mathrm{E}-04$ & Yes \\
\hline Sm-147 & 2.97E-08 & $6.45 \mathrm{E}-10$ & \\
\hline Sm-151 & $8.34 E+00$ & $1.81 \mathrm{E}-01$ & Yes \\
\hline Sn-121 & 1.04E-02 & $2.25 \mathrm{E}-04$ & \\
\hline Sn-121m & 1.33E-02 & 2.90E-04 & Yes \\
\hline Sn-126 & 1.42E-02 & $3.07 \mathrm{E}-04$ & Yes \\
\hline Sr-90 & 2.80E-01 & $6.08 \mathrm{E}-03$ & Yes \\
\hline Tc-99 & 1.96E-01 & $4.25 \mathrm{E}-03$ & Yes \\
\hline Te-125m & $5.58 \mathrm{E}-47$ & $1.21 \mathrm{E}-48$ & \\
\hline Th-227 & $5.75 \mathrm{E}-06$ & $1.25 \mathrm{E}-07$ & \\
\hline Th-228 & 3.01E-05 & $6.53 E-07$ & \\
\hline Th-229 & 5.93E-04 & 1.29E-05 & \\
\hline Th-230 & 1.36E-04 & $2.95 \mathrm{E}-06$ & \\
\hline Th-231 & 7.35E-04 & 1.59E-05 & \\
\hline Th-232 & 3.01E-05 & $6.53 E-07$ & \\
\hline Th-234 & $2.26 \mathrm{E}-02$ & $4.90 \mathrm{E}-04$ & \\
\hline TI-207 & $5.82 \mathrm{E}-06$ & $1.26 \mathrm{E}-07$ & \\
\hline TI-208 & 1.08E-05 & $2.35 \mathrm{E}-07$ & \\
\hline TI-209 & $1.28 \mathrm{E}-05$ & $2.78 \mathrm{E}-07$ & \\
\hline U-233 & 1.56E-02 & 3.39E-04 & Yes \\
\hline U-234 & 3.92E-02 & $8.52 \mathrm{E}-04$ & Yes \\
\hline U-235 & 7.35E-04 & $1.59 \mathrm{E}-05$ & \\
\hline U-236 & $9.05 \mathrm{E}-04$ & 1.96E-05 & \\
\hline U-237 & 2.74E-07 & $5.94 \mathrm{E}-09$ & \\
\hline U-238 & $2.26 \mathrm{E}-02$ & $4.90 \mathrm{E}-04$ & Yes \\
\hline U-240 & 8.73E-08 & $1.89 \mathrm{E}-09$ & \\
\hline Y-90 & 2.80E-01 & $6.08 \mathrm{E}-03$ & \\
\hline Zr-93 & 4.43E-02 & $9.61 \mathrm{E}-04$ & Yes \\
\hline TOTAL & $4.61 \mathrm{E}+01$ & $1.00 \mathrm{E}+00$ & \\
\hline
\end{tabular}


WSRC-TR-2005-00157

Revision 0

APPENDIX F. ACTIVITIES OF DRIED SLUDGE IN YEAR $2515(\mu \mathrm{Ci} / \mathrm{g})$ 
WSRC-TR-2005-00157

Revision 0

\begin{tabular}{|c|c|c|c|}
\hline Nuclide & $\begin{array}{l}\text { Y } 2515 \\
\mu \mathrm{Ci} / \mathrm{g}\end{array}$ & $\begin{array}{c}\text { Fraction of } \\
\text { Activity }\end{array}$ & Reportable \\
\hline Ac-225 & $7.34 \mathrm{E}-04$ & 1.97E-05 & \\
\hline Ac-227 & 7.38E-06 & 1.98E-07 & \\
\hline Ac-228 & $3.01 \mathrm{E}-05$ & 8.06E-07 & \\
\hline Am-241 & $9.00 \mathrm{E}+00$ & 2.41E-01 & Yes \\
\hline Am-242 & $8.68 \mathrm{E}-03$ & $2.33 \mathrm{E}-04$ & \\
\hline Am-242m & 8.73E-03 & $2.34 \mathrm{E}-04$ & Yes \\
\hline Am-243 & $1.48 \mathrm{E}+00$ & 3.96E-02 & Yes \\
\hline At-217 & 7.34E-04 & 1.97E-05 & \\
\hline At-218 & 3.41E-09 & $9.13 \mathrm{E}-11$ & \\
\hline $\mathrm{Ba}-137 \mathrm{~m}$ & $2.27 \mathrm{E}-03$ & 6.09E-05 & \\
\hline Bi-210 & 1.50E-05 & 4.02E-07 & \\
\hline $\mathrm{Bi}-211$ & 7.38E-06 & 1.98E-07 & \\
\hline $\mathrm{Bi}-212$ & $3.01 \mathrm{E}-05$ & 8.06E-07 & \\
\hline $\mathrm{Bi}-213$ & 7.34E-04 & 1.97E-05 & \\
\hline $\mathrm{Bi}-214$ & 1.70E-05 & 4.56E-07 & \\
\hline Cf-249 & $1.03 \mathrm{E}-02$ & $2.77 \mathrm{E}-04$ & Yes \\
\hline Cf-250 & $1.37 \mathrm{E}-14$ & 3.66E-16 & \\
\hline Cf-251 & 1.51E-02 & 4.05E-04 & Yes \\
\hline $\mathrm{Cm}-242$ & $7.20 \mathrm{E}-03$ & 1.93E-04 & \\
\hline $\mathrm{Cm}-243$ & $1.05 \mathrm{E}-06$ & 2.80E-08 & \\
\hline $\mathrm{Cm}-244$ & 2.33E-07 & $6.25 \mathrm{E}-09$ & \\
\hline $\mathrm{Cm}-245$ & $1.12 \mathrm{E}-02$ & $2.99 \mathrm{E}-04$ & Yes \\
\hline $\mathrm{Cm}-246$ & 1.51E-02 & 4.03E-04 & Yes \\
\hline $\mathrm{Cm}-247$ & $2.65 \mathrm{E}-02$ & 7.10E-04 & Yes \\
\hline $\mathrm{Cm}-248$ & 2.77E-02 & 7.41E-04 & Yes \\
\hline Co-60 & $1.21 \mathrm{E}-29$ & $3.25 \mathrm{E}-31$ & \\
\hline Cs-135 & $1.34 \mathrm{E}-03$ & $3.59 \mathrm{E}-05$ & \\
\hline Cs-137 & $2.40 \mathrm{E}-03$ & $6.44 \mathrm{E}-05$ & \\
\hline Eu-154 & $2.77 \mathrm{E}-17$ & 7.42E-19 & \\
\hline Eu-155 & $2.37 \mathrm{E}-31$ & $6.34 \mathrm{E}-33$ & \\
\hline Fr-221 & 7.34E-04 & 1.97E-05 & \\
\hline Fr-223 & 1.02E-07 & 2.73E-09 & \\
\hline I-129 & $4.35 \mathrm{E}-04$ & 1.16E-05 & \\
\hline $\mathrm{Nb}-93 \mathrm{~m}$ & 4.43E-02 & 1.19E-03 & Yes \\
\hline $\mathrm{Ni}-59$ & $6.60 \mathrm{E}-01$ & 1.77E-02 & Yes \\
\hline $\mathrm{Ni}-63$ & $1.36 \mathrm{E}+00$ & $3.65 \mathrm{E}-02$ & Yes \\
\hline Np-237 & 3.53E-02 & $9.45 \mathrm{E}-04$ & Yes \\
\hline Np-238 & $4.15 \mathrm{E}-05$ & 1.11E-06 & \\
\hline Np-239 & $1.48 \mathrm{E}+00$ & 3.96E-02 & \\
\hline $\mathrm{Np}-240 \mathrm{~m}$ & 1.09E-07 & 2.91E-09 & \\
\hline Pa-231 & 7.86E-06 & 2.11E-07 & \\
\hline $\mathrm{Pa}-233$ & 3.53E-02 & $9.45 \mathrm{E}-04$ & \\
\hline $\mathrm{Pa}-234$ & 7.45E-05 & 2.00E-06 & \\
\hline $\mathrm{Pa}-234 \mathrm{~m}$ & $2.26 \mathrm{E}-02$ & 6.04E-04 & \\
\hline Pb-209 & 7.34E-04 & 1.97E-05 & \\
\hline $\mathrm{Pb}-210$ & $1.50 \mathrm{E}-05$ & 4.02E-07 & \\
\hline $\mathrm{Pb}-211$ & 7.38E-06 & 1.98E-07 & \\
\hline $\mathrm{Pb}-212$ & $3.01 \mathrm{E}-05$ & 8.06E-07 & \\
\hline $\mathrm{Pb}-214$ & 1.70E-05 & 4.56E-07 & \\
\hline Pd-107 & $6.89 \mathrm{E}-04$ & 1.85E-05 & \\
\hline Pm-147 & $3.62 E-56$ & $9.70 \mathrm{E}-58$ & \\
\hline Po-210 & $1.50 \mathrm{E}-05$ & $4.01 \mathrm{E}-07$ & \\
\hline Po-211 & 2.07E-08 & $5.53 \mathrm{E}-10$ & \\
\hline Po-212 & 1.93E-05 & 5.16E-07 & \\
\hline Po-213 & 7.18E-04 & 1.92E-05 & \\
\hline Po-214 & 1.70E-05 & 4.56E-07 & \\
\hline Po-215 & 7.38E-06 & 1.98E-07 & \\
\hline Po-216 & $3.01 \mathrm{E}-05$ & 8.06E-07 & \\
\hline
\end{tabular}

\begin{tabular}{|c|c|c|c|}
\hline Nuclide & $\begin{array}{l}\mathrm{Y} 2515 \\
\mu \mathrm{Ci} / \mathrm{g}\end{array}$ & $\begin{array}{c}\text { Fraction of } \\
\text { Activity }\end{array}$ & Reportable \\
\hline Po-218 & 1.70E-05 & $4.56 \mathrm{E}-07$ & \\
\hline Pu-238 & 4.75E-01 & $1.27 \mathrm{E}-02$ & Yes \\
\hline Pu-239 & $1.35 \mathrm{E}+01$ & $3.62 \mathrm{E}-01$ & Yes \\
\hline Pu-240 & $4.73 E+00$ & $1.27 \mathrm{E}-01$ & Yes \\
\hline Pu-241 & 1.12E-02 & $2.99 \mathrm{E}-04$ & Yes \\
\hline Pu-242 & $5.48 \mathrm{E}-03$ & 1.47E-04 & Yes \\
\hline Pu-243 & $2.65 \mathrm{E}-02$ & 7.10E-04 & \\
\hline Pu-244 & 1.09E-07 & 2.91E-09 & \\
\hline Ra-223 & 7.38E-06 & $1.98 \mathrm{E}-07$ & \\
\hline Ra-224 & 3.01E-05 & 8.06E-07 & \\
\hline Ra-225 & 7.34E-04 & $1.97 \mathrm{E}-05$ & \\
\hline Ra-226 & 1.70E-05 & 4.56E-07 & \\
\hline Ra-228 & 3.01E-05 & 8.06E-07 & \\
\hline Rn-219 & 7.38E-06 & $1.98 \mathrm{E}-07$ & \\
\hline Rn-220 & 3.01E-05 & 8.06E-07 & \\
\hline Rn-222 & 1.70E-05 & 4.56E-07 & \\
\hline Sb-125 & 3.13E-57 & $8.38 \mathrm{E}-59$ & \\
\hline Sb-126 & $1.98 \mathrm{E}-03$ & 5.31E-05 & \\
\hline Sb-126m & 1.42E-02 & 3.79E-04 & \\
\hline Se-79 & 1.96E-02 & $5.25 \mathrm{E}-04$ & Yes \\
\hline Sm-147 & $2.97 \mathrm{E}-08$ & 7.95E-10 & \\
\hline Sm-151 & $3.86 \mathrm{E}+00$ & 1.03E-01 & Yes \\
\hline Sn-121 & $2.94 \mathrm{E}-03$ & $7.86 \mathrm{E}-05$ & \\
\hline $\mathrm{Sn}-121 \mathrm{~m}$ & $3.78 \mathrm{E}-03$ & $1.01 \mathrm{E}-04$ & Yes \\
\hline Sn-126 & 1.42E-02 & $3.79 \mathrm{E}-04$ & Yes \\
\hline Sr-90 & $2.59 \mathrm{E}-02$ & $6.94 \mathrm{E}-04$ & Yes \\
\hline TC-99 & 1.96E-01 & $5.24 \mathrm{E}-03$ & Yes \\
\hline Te-125m & 7.57E-58 & 2.03E-59 & \\
\hline Th-227 & 7.27E-06 & 1.95E-07 & \\
\hline Th-228 & $3.01 \mathrm{E}-05$ & 8.06E-07 & \\
\hline Th-229 & 7.34E-04 & 1.97E-05 & \\
\hline Th-230 & 1.71E-04 & $4.58 \mathrm{E}-06$ & \\
\hline Th-231 & 7.36E-04 & $1.97 \mathrm{E}-05$ & \\
\hline Th-232 & 3.01E-05 & 8.06E-07 & \\
\hline Th-234 & $2.26 \mathrm{E}-02$ & $6.05 \mathrm{E}-04$ & \\
\hline TI-207 & $7.35 \mathrm{E}-06$ & $1.97 \mathrm{E}-07$ & \\
\hline TI-208 & 1.08E-05 & $2.90 \mathrm{E}-07$ & \\
\hline TI-209 & $1.59 \mathrm{E}-05$ & 4.25E-07 & \\
\hline U-233 & 1.56E-02 & 4.19E-04 & Yes \\
\hline U-234 & 3.94E-02 & 1.06E-03 & Yes \\
\hline U-235 & 7.36E-04 & $1.97 \mathrm{E}-05$ & \\
\hline U-236 & $9.19 \mathrm{E}-04$ & $2.46 \mathrm{E}-05$ & \\
\hline U-237 & 2.74E-07 & 7.34E-09 & \\
\hline U-238 & $2.26 \mathrm{E}-02$ & $6.05 E-04$ & Yes \\
\hline U-240 & $1.09 \mathrm{E}-07$ & 2.91E-09 & \\
\hline Y-90 & $2.59 \mathrm{E}-02$ & $6.94 \mathrm{E}-04$ & \\
\hline Zr-93 & 4.43E-02 & 1.19E-03 & Yes \\
\hline TOTAL & $3.73 \mathrm{E}+01$ & $1.00 \mathrm{E}+00$ & \\
\hline
\end{tabular}


WSRC-TR-2005-00157

Revision 0

\section{APPENDIX G. ACTIVITIES OF DRIED SLUDGE IN YEAR $2615(\mu \mathrm{Ci} / \mathrm{g})$}


WSRC-TR-2005-00157

Revision 0

\begin{tabular}{|c|c|c|c|}
\hline Nuclide & $\begin{array}{l}\text { Y } 2615 \\
\mu \mathrm{Ci} / \mathrm{g}\end{array}$ & $\begin{array}{c}\text { Fraction of } \\
\text { Activity }\end{array}$ & Reportable \\
\hline Ac-225 & $8.74 \mathrm{E}-04$ & 2.67E-05 & \\
\hline Ac-227 & 8.92E-06 & $2.72 \mathrm{E}-07$ & \\
\hline Ac-228 & $3.01 \mathrm{E}-05$ & $9.18 \mathrm{E}-07$ & \\
\hline Am-241 & $7.66 \mathrm{E}+00$ & 2.34E-01 & Yes \\
\hline Am-242 & $5.50 \mathrm{E}-03$ & $1.68 \mathrm{E}-04$ & \\
\hline Am-242m & $5.53 \mathrm{E}-03$ & $1.69 \mathrm{E}-04$ & Yes \\
\hline Am-243 & $1.47 \mathrm{E}+00$ & 4.47E-02 & Yes \\
\hline At-217 & 8.74E-04 & $2.67 \mathrm{E}-05$ & \\
\hline At-218 & 4.86E-09 & $1.48 \mathrm{E}-10$ & \\
\hline $\mathrm{Ba}-137 \mathrm{~m}$ & $2.26 \mathrm{E}-04$ & $6.88 \mathrm{E}-06$ & \\
\hline Bi-210 & 2.19E-05 & $6.68 \mathrm{E}-07$ & \\
\hline $\mathrm{Bi}-211$ & 8.92E-06 & $2.72 \mathrm{E}-07$ & \\
\hline $\mathrm{Bi}-212$ & $3.01 \mathrm{E}-05$ & $9.18 \mathrm{E}-07$ & \\
\hline $\mathrm{Bi}-213$ & 8.74E-04 & 2.67E-05 & \\
\hline $\mathrm{Bi}-214$ & 2.43E-05 & 7.42E-07 & \\
\hline Cf-249 & 8.47E-03 & $2.58 \mathrm{E}-04$ & Yes \\
\hline Cf-250 & $6.83 \mathrm{E}-17$ & $2.08 \mathrm{E}-18$ & \\
\hline Cf-251 & 1.40E-02 & 4.26E-04 & Yes \\
\hline $\mathrm{Cm}-242$ & $4.56 \mathrm{E}-03$ & $1.39 \mathrm{E}-04$ & \\
\hline $\mathrm{Cm}-243$ & $9.20 \mathrm{E}-08$ & 2.80E-09 & \\
\hline $\mathrm{Cm}-244$ & $5.08 \mathrm{E}-09$ & $1.55 \mathrm{E}-10$ & \\
\hline $\mathrm{Cm}-245$ & 1.12E-02 & 3.40E-04 & Yes \\
\hline $\mathrm{Cm}-246$ & 1.48E-02 & 4.52E-04 & Yes \\
\hline $\mathrm{Cm}-247$ & $2.65 \mathrm{E}-02$ & 8.08E-04 & Yes \\
\hline $\mathrm{Cm}-248$ & 2.77E-02 & 8.43E-04 & Yes \\
\hline Co-60 & $2.36 \mathrm{E}-35$ & $7.20 \mathrm{E}-37$ & \\
\hline Cs-135 & $1.34 \mathrm{E}-03$ & $4.08 \mathrm{E}-05$ & \\
\hline Cs-137 & $2.39 \mathrm{E}-04$ & 7.27E-06 & \\
\hline Eu-154 & $1.05 \mathrm{E}-20$ & $3.21 \mathrm{E}-22$ & \\
\hline Eu-155 & $2.02 \mathrm{E}-37$ & $6.16 \mathrm{E}-39$ & \\
\hline Fr-221 & 8.74E-04 & 2.67E-05 & \\
\hline Fr-223 & 1.23E-07 & 3.75E-09 & \\
\hline I-129 & $4.35 \mathrm{E}-04$ & 1.33E-05 & \\
\hline $\mathrm{Nb}-93 \mathrm{~m}$ & 4.43E-02 & 1.35E-03 & Yes \\
\hline $\mathrm{Ni}-59$ & $6.59 \mathrm{E}-01$ & 2.01E-02 & Yes \\
\hline $\mathrm{Ni}-63$ & $6.61 \mathrm{E}-01$ & 2.02E-02 & Yes \\
\hline Np-237 & 3.55E-02 & $1.08 \mathrm{E}-03$ & Yes \\
\hline Np-238 & 2.63E-05 & 8.03E-07 & \\
\hline Np-239 & $1.47 E+00$ & 4.47E-02 & \\
\hline $\mathrm{Np}-240 \mathrm{~m}$ & 1.30E-07 & 3.96E-09 & \\
\hline Pa-231 & $9.40 \mathrm{E}-06$ & 2.87E-07 & \\
\hline $\mathrm{Pa}-233$ & $3.55 \mathrm{E}-02$ & 1.08E-03 & \\
\hline $\mathrm{Pa}-234$ & 7.45E-05 & 2.27E-06 & \\
\hline $\mathrm{Pa}-234 \mathrm{~m}$ & $2.26 \mathrm{E}-02$ & 6.88E-04 & \\
\hline Pb-209 & 8.74E-04 & 2.67E-05 & \\
\hline $\mathrm{Pb}-210$ & $2.19 \mathrm{E}-05$ & $6.68 \mathrm{E}-07$ & \\
\hline $\mathrm{Pb}-211$ & 8.92E-06 & 2.72E-07 & \\
\hline $\mathrm{Pb}-212$ & $3.01 \mathrm{E}-05$ & $9.18 \mathrm{E}-07$ & \\
\hline $\mathrm{Pb}-214$ & 2.43E-05 & 7.41E-07 & \\
\hline Pd-107 & $6.89 \mathrm{E}-04$ & 2.10E-05 & \\
\hline Pm-147 & 1.22E-67 & 3.70E-69 & \\
\hline Po-210 & 2.19E-05 & 6.67E-07 & \\
\hline Po-211 & $2.50 \mathrm{E}-08$ & 7.61E-10 & \\
\hline Po-212 & 1.93E-05 & $5.88 \mathrm{E}-07$ & \\
\hline Po-213 & 8.56E-04 & 2.61E-05 & \\
\hline Po-214 & 2.43E-05 & 7.41E-07 & \\
\hline Po-215 & 8.92E-06 & $2.72 \mathrm{E}-07$ & \\
\hline Po-216 & $3.01 \mathrm{E}-05$ & $9.18 \mathrm{E}-07$ & \\
\hline
\end{tabular}

\begin{tabular}{|c|c|c|c|}
\hline Nuclide & $\begin{array}{l}\text { Y } 2615 \\
\mu \mathrm{Ci} / \mathrm{g}\end{array}$ & $\begin{array}{c}\text { Fraction of } \\
\text { Activity }\end{array}$ & Reportable \\
\hline Po-218 & $2.43 \mathrm{E}-05$ & $7.42 \mathrm{E}-07$ & \\
\hline Pu-238 & 2.19E-01 & $6.66 \mathrm{E}-03$ & Yes \\
\hline Pu-239 & $1.35 \mathrm{E}+01$ & 4.11E-01 & Yes \\
\hline Pu-240 & $4.68 \mathrm{E}+00$ & 1.43E-01 & Yes \\
\hline Pu-241 & 1.12E-02 & $3.41 \mathrm{E}-04$ & Yes \\
\hline Pu-242 & $5.48 \mathrm{E}-03$ & 1.67E-04 & Yes \\
\hline Pu-243 & $2.65 \mathrm{E}-02$ & 8.08E-04 & \\
\hline Pu-244 & 1.30E-07 & 3.96E-09 & \\
\hline Ra-223 & 8.92E-06 & $2.72 \mathrm{E}-07$ & \\
\hline Ra-224 & 3.01E-05 & $9.18 \mathrm{E}-07$ & \\
\hline Ra-225 & 8.75E-04 & $2.67 \mathrm{E}-05$ & \\
\hline Ra-226 & 2.43E-05 & 7.42E-07 & \\
\hline Ra-228 & 3.01E-05 & $9.18 \mathrm{E}-07$ & \\
\hline Rn-219 & 8.92E-06 & $2.72 \mathrm{E}-07$ & \\
\hline Rn-220 & 3.01E-05 & $9.18 \mathrm{E}-07$ & \\
\hline Rn-222 & 2.43E-05 & $7.42 \mathrm{E}-07$ & \\
\hline Sb-125 & $4.25 \mathrm{E}-68$ & $1.30 \mathrm{E}-69$ & \\
\hline Sb-126 & $1.98 \mathrm{E}-03$ & $6.04 \mathrm{E}-05$ & \\
\hline Sb-126m & $1.41 \mathrm{E}-02$ & 4.31E-04 & \\
\hline Se-79 & 1.96E-02 & $5.97 \mathrm{E}-04$ & Yes \\
\hline Sm-147 & 2.97E-08 & $9.05 E-10$ & \\
\hline Sm-151 & $1.79 E+00$ & $5.45 \mathrm{E}-02$ & Yes \\
\hline Sn-121 & 8.33E-04 & $2.54 \mathrm{E}-05$ & \\
\hline $\mathrm{Sn}-121 \mathrm{~m}$ & $1.07 \mathrm{E}-03$ & $3.27 \mathrm{E}-05$ & \\
\hline Sn-126 & 1.41E-02 & $4.31 \mathrm{E}-04$ & Yes \\
\hline Sr-90 & $2.40 \mathrm{E}-03$ & 7.31E-05 & \\
\hline TC-99 & 1.96E-01 & $5.96 \mathrm{E}-03$ & Yes \\
\hline Te-125m & 1.03E-68 & $3.13 E-70$ & \\
\hline Th-227 & 8.79E-06 & $2.68 \mathrm{E}-07$ & \\
\hline Th-228 & $3.01 \mathrm{E}-05$ & $9.18 \mathrm{E}-07$ & \\
\hline Th-229 & 8.75E-04 & 2.67E-05 & \\
\hline Th-230 & 2.06E-04 & $6.29 \mathrm{E}-06$ & \\
\hline Th-231 & 7.37E-04 & $2.25 \mathrm{E}-05$ & \\
\hline Th-232 & 3.01E-05 & $9.18 \mathrm{E}-07$ & \\
\hline Th-234 & $2.26 \mathrm{E}-02$ & $6.89 \mathrm{E}-04$ & \\
\hline TI-207 & $8.89 \mathrm{E}-06$ & $2.71 \mathrm{E}-07$ & \\
\hline TI-208 & 1.08E-05 & $3.30 \mathrm{E}-07$ & \\
\hline TI-209 & $1.89 \mathrm{E}-05$ & $5.76 \mathrm{E}-07$ & \\
\hline U-233 & 1.57E-02 & $4.77 \mathrm{E}-04$ & Yes \\
\hline U-234 & 3.95E-02 & $1.21 \mathrm{E}-03$ & Yes \\
\hline U-235 & 7.37E-04 & $2.25 \mathrm{E}-05$ & \\
\hline U-236 & 9.33E-04 & $2.85 \mathrm{E}-05$ & \\
\hline U-237 & 2.74E-07 & 8.34E-09 & \\
\hline U-238 & $2.26 \mathrm{E}-02$ & $6.89 \mathrm{E}-04$ & Yes \\
\hline U-240 & 1.30E-07 & 3.96E-09 & \\
\hline Y-90 & $2.40 \mathrm{E}-03$ & 7.32E-05 & \\
\hline Zr-93 & 4.43E-02 & 1.35E-03 & Yes \\
\hline TOTAL & $3.28 \mathrm{E}+01$ & $1.00 \mathrm{E}+00$ & \\
\hline
\end{tabular}


WSRC-TR-2005-00157

Revision 0

\section{APPENDIX H. ACTIVITIES OF DRIED SLUDGE IN YEAR $2715(\mu \mathrm{Ci} / \mathrm{g})$}


WSRC-TR-2005-00157

Revision 0

\begin{tabular}{|c|c|c|c|}
\hline Nuclide & $\begin{array}{l}\text { Y } 2715 \\
\mu \mathrm{Ci} / \mathrm{g}\end{array}$ & $\begin{array}{c}\text { Fraction of } \\
\text { Activity }\end{array}$ & Reportable \\
\hline Ac-225 & $1.01 \mathrm{E}-03$ & 3.36E-05 & \\
\hline Ac-227 & $1.05 \mathrm{E}-05$ & $3.47 \mathrm{E}-07$ & \\
\hline Ac-228 & $3.01 \mathrm{E}-05$ & $9.99 \mathrm{E}-07$ & \\
\hline Am-241 & $6.53 E+00$ & 2.17E-01 & Yes \\
\hline Am-242 & $3.49 \mathrm{E}-03$ & 1.16E-04 & \\
\hline Am-242m & $3.51 \mathrm{E}-03$ & 1.16E-04 & Yes \\
\hline Am-243 & $1.45 \mathrm{E}+00$ & 4.82E-02 & Yes \\
\hline At-217 & $1.01 \mathrm{E}-03$ & 3.36E-05 & \\
\hline At-218 & 6.56E-09 & $2.18 \mathrm{E}-10$ & \\
\hline $\mathrm{Ba}-137 \mathrm{~m}$ & $2.24 \mathrm{E}-05$ & 7.43E-07 & \\
\hline Bi-210 & $3.00 \mathrm{E}-05$ & 9.96E-07 & \\
\hline $\mathrm{Bi}-211$ & $1.05 \mathrm{E}-05$ & 3.47E-07 & \\
\hline $\mathrm{Bi}-212$ & $3.01 \mathrm{E}-05$ & 9.99E-07 & \\
\hline $\mathrm{Bi}-213$ & $1.01 \mathrm{E}-03$ & 3.36E-05 & \\
\hline $\mathrm{Bi}-214$ & $3.28 \mathrm{E}-05$ & 1.09E-06 & \\
\hline Cf-249 & $6.95 \mathrm{E}-03$ & $2.31 \mathrm{E}-04$ & Yes \\
\hline Cf-250 & 3.41E-19 & 1.13E-20 & \\
\hline Cf-251 & $1.29 \mathrm{E}-02$ & 4.30E-04 & Yes \\
\hline $\mathrm{Cm}-242$ & $2.89 \mathrm{E}-03$ & $9.60 \mathrm{E}-05$ & \\
\hline $\mathrm{Cm}-243$ & 8.08E-09 & $2.68 \mathrm{E}-10$ & \\
\hline $\mathrm{Cm}-244$ & $1.11 \mathrm{E}-10$ & 3.67E-12 & \\
\hline $\mathrm{Cm}-245$ & $1.11 \mathrm{E}-02$ & 3.70E-04 & Yes \\
\hline $\mathrm{Cm}-246$ & 1.46E-02 & 4.85E-04 & Yes \\
\hline $\mathrm{Cm}-247$ & $2.65 \mathrm{E}-02$ & 8.80E-04 & Yes \\
\hline $\mathrm{Cm}-248$ & 2.77E-02 & $9.18 \mathrm{E}-04$ & Yes \\
\hline Co-60 & $4.59 \mathrm{E}-41$ & 1.52E-42 & \\
\hline Cs-135 & $1.34 \mathrm{E}-03$ & 4.45E-05 & \\
\hline Cs-137 & $2.37 \mathrm{E}-05$ & 7.86E-07 & \\
\hline Eu-154 & $3.99 \mathrm{E}-24$ & $1.33 \mathrm{E}-25$ & \\
\hline Eu-155 & $1.72 \mathrm{E}-43$ & $5.72 \mathrm{E}-45$ & \\
\hline Fr-221 & $1.01 \mathrm{E}-03$ & 3.36E-05 & \\
\hline Fr-223 & 1.44E-07 & 4.79E-09 & \\
\hline I-129 & $4.35 \mathrm{E}-04$ & 1.44E-05 & \\
\hline $\mathrm{Nb}-93 \mathrm{~m}$ & 4.43E-02 & 1.47E-03 & Yes \\
\hline $\mathrm{Ni}-59$ & $6.59 \mathrm{E}-01$ & 2.19E-02 & Yes \\
\hline $\mathrm{Ni}-63$ & 3.21E-01 & 1.07E-02 & Yes \\
\hline Np-237 & $3.58 \mathrm{E}-02$ & 1.19E-03 & Yes \\
\hline Np-238 & 1.67E-05 & 5.54E-07 & \\
\hline Np-239 & $1.45 E+00$ & 4.82E-02 & \\
\hline $\mathrm{Np}-240 \mathrm{~m}$ & 1.51E-07 & 5.02E-09 & \\
\hline Pa-231 & 1.09E-05 & 3.63E-07 & \\
\hline $\mathrm{Pa}-233$ & $3.58 \mathrm{E}-02$ & 1.19E-03 & \\
\hline $\mathrm{Pa}-234$ & 7.45E-05 & 2.47E-06 & \\
\hline $\mathrm{Pa}-234 \mathrm{~m}$ & $2.26 \mathrm{E}-02$ & 7.49E-04 & \\
\hline Pb-209 & $1.01 \mathrm{E}-03$ & 3.36E-05 & \\
\hline $\mathrm{Pb}-210$ & $3.00 \mathrm{E}-05$ & 9.96E-07 & \\
\hline $\mathrm{Pb}-211$ & 1.05E-05 & 3.47E-07 & \\
\hline $\mathrm{Pb}-212$ & $3.01 \mathrm{E}-05$ & $9.99 \mathrm{E}-07$ & \\
\hline $\mathrm{Pb}-214$ & $3.28 \mathrm{E}-05$ & $1.09 \mathrm{E}-06$ & \\
\hline Pd-107 & $6.89 \mathrm{E}-04$ & 2.29E-05 & \\
\hline Pm-147 & 4.07E-79 & $1.35 \mathrm{E}-80$ & \\
\hline Po-210 & 2.99E-05 & 9.94E-07 & \\
\hline Po-211 & 2.93E-08 & $9.72 \mathrm{E}-10$ & \\
\hline Po-212 & 1.93E-05 & $6.40 \mathrm{E}-07$ & \\
\hline Po-213 & $9.92 \mathrm{E}-04$ & 3.29E-05 & \\
\hline Po-214 & $3.28 \mathrm{E}-05$ & 1.09E-06 & \\
\hline Po-215 & $1.05 \mathrm{E}-05$ & $3.47 \mathrm{E}-07$ & \\
\hline Po-216 & $3.01 \mathrm{E}-05$ & $9.99 \mathrm{E}-07$ & \\
\hline
\end{tabular}

\begin{tabular}{|c|c|c|c|}
\hline Nuclide & $\begin{array}{l}\text { Y } 2715 \\
\mu \mathrm{Ci} / \mathrm{g}\end{array}$ & $\begin{array}{c}\text { Fraction of } \\
\text { Activity }\end{array}$ & Reportable \\
\hline Po-218 & $3.28 \mathrm{E}-05$ & 1.09E-06 & \\
\hline Pu-238 & $1.01 \mathrm{E}-01$ & $3.36 \mathrm{E}-03$ & Yes \\
\hline Pu-239 & $1.35 \mathrm{E}+01$ & 4.47E-01 & Yes \\
\hline Pu-240 & $4.63 E+00$ & $1.54 \mathrm{E}-01$ & Yes \\
\hline Pu-241 & 1.11E-02 & $3.70 \mathrm{E}-04$ & Yes \\
\hline Pu-242 & $5.48 \mathrm{E}-03$ & $1.82 \mathrm{E}-04$ & Yes \\
\hline Pu-243 & $2.65 \mathrm{E}-02$ & $8.80 \mathrm{E}-04$ & \\
\hline Pu-244 & $1.51 \mathrm{E}-07$ & 5.02E-09 & \\
\hline Ra-223 & 1.05E-05 & 3.47E-07 & \\
\hline Ra-224 & 3.01E-05 & $9.99 \mathrm{E}-07$ & \\
\hline Ra-225 & $1.01 \mathrm{E}-03$ & 3.36E-05 & \\
\hline Ra-226 & $3.28 \mathrm{E}-05$ & 1.09E-06 & \\
\hline Ra-228 & 3.01E-05 & $9.99 \mathrm{E}-07$ & \\
\hline Rn-219 & 1.05E-05 & $3.47 \mathrm{E}-07$ & \\
\hline Rn-220 & 3.01E-05 & $9.99 \mathrm{E}-07$ & \\
\hline Rn-222 & $3.28 \mathrm{E}-05$ & 1.09E-06 & \\
\hline Sb-125 & 5.77E-79 & $1.92 \mathrm{E}-80$ & \\
\hline Sb-126 & $1.98 \mathrm{E}-03$ & $6.57 \mathrm{E}-05$ & \\
\hline Sb-126m & $1.41 \mathrm{E}-02$ & 4.69E-04 & \\
\hline Se-79 & 1.96E-02 & $6.49 \mathrm{E}-04$ & Yes \\
\hline Sm-147 & 2.97E-08 & $9.86 \mathrm{E}-10$ & \\
\hline Sm-151 & 8.27E-01 & $2.75 \mathrm{E}-02$ & Yes \\
\hline Sn-121 & $2.36 \mathrm{E}-04$ & 7.84E-06 & \\
\hline $\mathrm{Sn}-121 \mathrm{~m}$ & 3.04E-04 & $1.01 \mathrm{E}-05$ & \\
\hline Sn-126 & 1.41E-02 & 4.69E-04 & Yes \\
\hline Sr-90 & $2.22 \mathrm{E}-04$ & 7.37E-06 & \\
\hline TC-99 & 1.96E-01 & $6.49 \mathrm{E}-03$ & Yes \\
\hline Te-125m & 1.40E-79 & 4.63E-81 & \\
\hline Th-227 & 1.03E-05 & $3.42 \mathrm{E}-07$ & \\
\hline Th-228 & $3.01 \mathrm{E}-05$ & $9.99 \mathrm{E}-07$ & \\
\hline Th-229 & $1.01 \mathrm{E}-03$ & 3.36E-05 & \\
\hline Th-230 & 2.42E-04 & 8.03E-06 & \\
\hline Th-231 & 7.38E-04 & $2.45 \mathrm{E}-05$ & \\
\hline Th-232 & 3.01E-05 & $9.99 \mathrm{E}-07$ & \\
\hline Th-234 & $2.26 \mathrm{E}-02$ & $7.50 \mathrm{E}-04$ & \\
\hline TI-207 & $1.04 \mathrm{E}-05$ & $3.46 \mathrm{E}-07$ & \\
\hline TI-208 & 1.08E-05 & $3.59 \mathrm{E}-07$ & \\
\hline TI-209 & $2.19 \mathrm{E}-05$ & 7.27E-07 & \\
\hline U-233 & 1.57E-02 & $5.20 \mathrm{E}-04$ & Yes \\
\hline U-234 & 3.96E-02 & 1.31E-03 & Yes \\
\hline U-235 & 7.38E-04 & $2.45 \mathrm{E}-05$ & \\
\hline U-236 & 9.47E-04 & 3.14E-05 & \\
\hline U-237 & 2.73E-07 & $9.06 \mathrm{E}-09$ & \\
\hline U-238 & $2.26 \mathrm{E}-02$ & $7.50 \mathrm{E}-04$ & Yes \\
\hline U-240 & $1.51 \mathrm{E}-07$ & $5.02 \mathrm{E}-09$ & \\
\hline Y-90 & $2.22 \mathrm{E}-04$ & 7.37E-06 & \\
\hline Zr-93 & 4.43E-02 & $1.47 \mathrm{E}-03$ & Yes \\
\hline TOTAL & $3.01 \mathrm{E}+01$ & $1.00 \mathrm{E}+00$ & \\
\hline
\end{tabular}


WSRC-TR-2005-00157

Revision 0

APPENDIX I. ACTIVITIES OF DRIED SLUDGE IN YEAR $2815(\mu \mathrm{Ci} / \mathrm{g})$ 
WSRC-TR-2005-00157

Revision 0

\begin{tabular}{|c|c|c|c|}
\hline Nuclide & $\begin{array}{l}\text { Y } 2815 \\
\mu \mathrm{Ci} / \mathrm{g}\end{array}$ & $\begin{array}{c}\text { Fraction of } \\
\text { Activity }\end{array}$ & Reportable \\
\hline Ac-225 & $1.15 \mathrm{E}-03$ & 4.06E-05 & \\
\hline Ac-227 & 1.20E-05 & 4.23E-07 & \\
\hline Ac-228 & 3.01E-05 & 1.06E-06 & \\
\hline Am-241 & $5.56 \mathrm{E}+00$ & 1.96E-01 & Yes \\
\hline Am-242 & $2.21 E-03$ & 7.79E-05 & \\
\hline$A m-242 m$ & $2.22 \mathrm{E}-03$ & 7.83E-05 & \\
\hline Am-243 & $1.44 \mathrm{E}+00$ & 5.07E-02 & Yes \\
\hline At-217 & $1.15 \mathrm{E}-03$ & 4.06E-05 & \\
\hline At-218 & 8.48E-09 & $2.99 \mathrm{E}-10$ & \\
\hline Ba-137m & $2.22 \mathrm{E}-06$ & 7.83E-08 & \\
\hline Bi-210 & 3.92E-05 & 1.38E-06 & \\
\hline Bi-211 & 1.20E-05 & 4.23E-07 & \\
\hline $\mathrm{Bi}-212$ & 3.01E-05 & 1.06E-06 & \\
\hline $\mathrm{Bi}-213$ & $1.15 E-03$ & 4.06E-05 & \\
\hline $\mathrm{Bi}-214$ & 4.24E-05 & 1.49E-06 & \\
\hline Cf-249 & 5.71E-03 & 2.01E-04 & Yes \\
\hline Cf-250 & $1.70 \mathrm{E}-21$ & 6.00E-23 & \\
\hline Cf-251 & 1.20E-02 & $4.22 \mathrm{E}-04$ & Yes \\
\hline $\mathrm{Cm}-242$ & $1.83 \mathrm{E}-03$ & 6.46E-05 & \\
\hline $\mathrm{Cm}-243$ & $7.10 \mathrm{E}-10$ & $2.50 \mathrm{E}-11$ & \\
\hline $\mathrm{Cm}-244$ & $2.41 \mathrm{E}-12$ & $8.48 \mathrm{E}-14$ & \\
\hline $\mathrm{Cm}-245$ & 1.11E-02 & 3.91E-04 & Yes \\
\hline $\mathrm{Cm}-246$ & 1.44E-02 & 5.08E-04 & Yes \\
\hline $\mathrm{Cm}-247$ & $2.65 \mathrm{E}-02$ & $9.34 \mathrm{E}-04$ & Yes \\
\hline $\mathrm{Cm}-248$ & 2.77E-02 & 9.74E-04 & Yes \\
\hline Co-60 & $8.93 E-47$ & $3.15 E-48$ & \\
\hline Cs-135 & $1.34 \mathrm{E}-03$ & 4.72E-05 & \\
\hline Cs-137 & $2.35 \mathrm{E}-06$ & 8.27E-08 & \\
\hline Eu-154 & $1.51 \mathrm{E}-27$ & 5.34E-29 & \\
\hline Eu-155 & 1.47E-49 & $5.18 E-51$ & \\
\hline Fr-221 & $1.15 \mathrm{E}-03$ & 4.06E-05 & \\
\hline Fr-223 & $1.66 \mathrm{E}-07$ & 5.83E-09 & \\
\hline $\mid-129$ & 4.35E-04 & 1.53E-05 & \\
\hline $\mathrm{Nb}-93 \mathrm{~m}$ & 4.43E-02 & 1.56E-03 & Yes \\
\hline $\mathrm{Ni}-59$ & 6.58E-01 & 2.32E-02 & Yes \\
\hline $\mathrm{Ni}-63$ & $1.56 \mathrm{E}-01$ & 5.50E-03 & Yes \\
\hline Np-237 & $3.60 \mathrm{E}-02$ & 1.27E-03 & Yes \\
\hline Np-238 & 1.06E-05 & 3.73E-07 & \\
\hline Np-239 & $1.44 \mathrm{E}+00$ & 5.07E-02 & \\
\hline $\mathrm{Np}-240 \mathrm{~m}$ & 1.72E-07 & 6.07E-09 & \\
\hline $\mathrm{Pa}-231$ & $1.25 \mathrm{E}-05$ & 4.40E-07 & \\
\hline $\mathrm{Pa}-233$ & $3.60 \mathrm{E}-02$ & 1.27E-03 & \\
\hline $\mathrm{Pa}-234$ & $7.45 \mathrm{E}-05$ & 2.63E-06 & \\
\hline $\mathrm{Pa}-234 \mathrm{~m}$ & $2.26 \mathrm{E}-02$ & 7.95E-04 & \\
\hline $\mathrm{Pb}-209$ & $1.15 \mathrm{E}-03$ & 4.06E-05 & \\
\hline $\mathrm{Pb}-210$ & 3.92E-05 & 1.38E-06 & \\
\hline $\mathrm{Pb}-211$ & 1.20E-05 & $4.23 \mathrm{E}-07$ & \\
\hline $\mathrm{Pb}-212$ & 3.01E-05 & 1.06E-06 & \\
\hline $\mathrm{Pb}-214$ & 4.24E-05 & $1.49 \mathrm{E}-06$ & \\
\hline Pd-107 & 6.89E-04 & 2.43E-05 & \\
\hline $\mathrm{Pm}-147$ & $1.37 \mathrm{E}-90$ & 4.81E-92 & \\
\hline Po-210 & $3.92 E-05$ & 1.38E-06 & \\
\hline Po-211 & $3.36 \mathrm{E}-08$ & 1.18E-09 & \\
\hline Po-212 & 1.93E-05 & $6.80 \mathrm{E}-07$ & \\
\hline Po-213 & $1.13 \mathrm{E}-03$ & 3.97E-05 & \\
\hline Рo-214 & 4.24E-05 & 1.49E-06 & \\
\hline Po-215 & $1.20 \mathrm{E}-05$ & $4.23 \mathrm{E}-07$ & \\
\hline Po-216 & 3.01E-05 & $1.06 \mathrm{E}-06$ & \\
\hline
\end{tabular}

\begin{tabular}{|c|c|c|c|}
\hline Nuclide & $\begin{array}{l}\text { Y } 2815 \\
\mu \mathrm{Ci} / \mathrm{g}\end{array}$ & $\begin{array}{c}\text { Fraction of } \\
\text { Activity }\end{array}$ & Reportable \\
\hline Po-218 & $4.24 \mathrm{E}-05$ & $1.49 \mathrm{E}-06$ & \\
\hline Pu-238 & 4.72E-02 & 1.66E-03 & Yes \\
\hline Pu-239 & $1.34 \mathrm{E}+01$ & 4.73E-01 & Yes \\
\hline Pu-240 & $4.58 \mathrm{E}+00$ & 1.62E-01 & Yes \\
\hline Pu-241 & 1.11E-02 & 3.91E-04 & Yes \\
\hline Pu-242 & 5.48E-03 & 1.93E-04 & Yes \\
\hline Pu-243 & 2.65E-02 & 9.34E-04 & \\
\hline Pu-244 & 1.73E-07 & 6.08E-09 & \\
\hline Ra-223 & 1.20E-05 & 4.23E-07 & \\
\hline Ra-224 & 3.01E-05 & $1.06 \mathrm{E}-06$ & \\
\hline $\mathrm{Ra}-225$ & 1.15E-03 & 4.06E-05 & \\
\hline $\mathrm{Ra}-226$ & 4.24E-05 & 1.49E-06 & \\
\hline $\mathrm{Ra}-228$ & 3.01E-05 & 1.06E-06 & \\
\hline Rn-219 & 1.20E-05 & 4.23E-07 & \\
\hline $\mathrm{Rn}-220$ & 3.01E-05 & 1.06E-06 & \\
\hline Rn-222 & 4.24E-05 & $1.49 \mathrm{E}-06$ & \\
\hline Sb-125 & 7.83E-90 & 2.76E-91 & \\
\hline Sb-126 & 1.98E-03 & 6.97E-05 & \\
\hline Sb-126m & 1.41E-02 & 4.98E-04 & \\
\hline Se-79 & $1.95 \mathrm{E}-02$ & 6.88E-04 & Yes \\
\hline Sm-147 & 2.97E-08 & 1.05E-09 & \\
\hline Sm-151 & 3.83E-01 & 1.35E-02 & Yes \\
\hline Sn-121 & 6.70E-05 & 2.36E-06 & \\
\hline Sn-121m & 8.63E-05 & 3.04E-06 & \\
\hline Sn-126 & 1.41E-02 & 4.98E-04 & Yes \\
\hline Sr-90 & 2.05E-05 & 7.24E-07 & \\
\hline Tc-99 & 1.95E-01 & 6.89E-03 & Yes \\
\hline $\mathrm{Te}-125 \mathrm{~m}$ & 1.89E-90 & 6.67E-92 & \\
\hline Th-227 & 1.18E-05 & 4.17E-07 & \\
\hline Th-228 & 3.01E-05 & $1.06 \mathrm{E}-06$ & \\
\hline Th-229 & 1.15E-03 & 4.06E-05 & \\
\hline Th-230 & 2.77E-04 & $9.77 \mathrm{E}-06$ & \\
\hline Th-231 & 7.40E-04 & 2.61E-05 & \\
\hline Th-232 & 3.01E-05 & 1.06E-06 & \\
\hline Th-234 & 2.26E-02 & 7.96E-04 & \\
\hline TI-207 & 1.20E-05 & 4.21E-07 & \\
\hline TI-208 & 1.08E-05 & 3.81E-07 & \\
\hline TI-209 & 2.49E-05 & 8.76E-07 & \\
\hline U-233 & 1.57E-02 & 5.52E-04 & Yes \\
\hline U-234 & 3.96E-02 & 1.39E-03 & Yes \\
\hline U-235 & 7.40E-04 & 2.61E-05 & \\
\hline U-236 & $9.61 \mathrm{E}-04$ & 3.38E-05 & \\
\hline U-237 & 2.72E-07 & 9.59E-09 & \\
\hline U-238 & 2.26E-02 & 7.96E-04 & Yes \\
\hline U-240 & 1.72E-07 & 6.07E-09 & \\
\hline Y-90 & 2.05E-05 & 7.24E-07 & \\
\hline Zr-93 & 4.43E-02 & $1.56 \mathrm{E}-03$ & Yes \\
\hline TOTAL & $2.84 E+01$ & $1.00 \mathrm{E}+00$ & \\
\hline
\end{tabular}


WSRC-TR-2005-00157

Revision 0

\section{APPENDIX J. ACTIVITIES OF DRIED SLUDGE IN YEAR $2915(\mu \mathrm{Ci} / \mathrm{g})$}


WSRC-TR-2005-00157

Revision 0

\begin{tabular}{|c|c|c|c|}
\hline Nuclide & $\begin{array}{l}\text { Y } 2915 \\
\mu \mathrm{Ci} / \mathrm{g}\end{array}$ & $\begin{array}{c}\text { Fraction of } \\
\text { Activity }\end{array}$ & Reportable \\
\hline Ac-225 & $1.29 \mathrm{E}-03$ & $4.75 \mathrm{E}-05$ & \\
\hline Ac-227 & 1.35E-05 & 4.99E-07 & \\
\hline Ac-228 & 3.01E-05 & $1.11 \mathrm{E}-06$ & \\
\hline Am-241 & $4.74 \mathrm{E}+00$ & 1.75E-01 & Yes \\
\hline Am-242 & 1.40E-03 & 5.16E-05 & \\
\hline Am-242m & $1.41 \mathrm{E}-03$ & $5.19 \mathrm{E}-05$ & \\
\hline Am-243 & $1.43 E+00$ & $5.25 \mathrm{E}-02$ & Yes \\
\hline At-217 & $1.29 \mathrm{E}-03$ & 4.75E-05 & \\
\hline At-218 & 1.06E-08 & $3.92 \mathrm{E}-10$ & \\
\hline $\mathrm{Ba}-137 \mathrm{~m}$ & $2.20 \mathrm{E}-07$ & 8.12E-09 & \\
\hline Bi-210 & 4.96E-05 & 1.83E-06 & \\
\hline $\mathrm{Bi}-211$ & 1.35E-05 & $4.99 \mathrm{E}-07$ & \\
\hline $\mathrm{Bi}-212$ & 3.01E-05 & 1.11E-06 & \\
\hline $\mathrm{Bi}-213$ & $1.29 \mathrm{E}-03$ & 4.75E-05 & \\
\hline $\mathrm{Bi}-214$ & 5.31E-05 & 1.96E-06 & \\
\hline Cf-249 & $4.68 \mathrm{E}-03$ & $1.73 \mathrm{E}-04$ & Yes \\
\hline Cf-250 & $8.51 \mathrm{E}-24$ & 3.14E-25 & \\
\hline Cf-251 & 1.11E-02 & 4.09E-04 & Yes \\
\hline $\mathrm{Cm}-242$ & 1.16E-03 & $4.28 \mathrm{E}-05$ & \\
\hline $\mathrm{Cm}-243$ & $6.24 \mathrm{E}-11$ & $2.30 \mathrm{E}-12$ & \\
\hline $\mathrm{Cm}-244$ & $5.24 \mathrm{E}-14$ & $1.93 \mathrm{E}-15$ & \\
\hline $\mathrm{Cm}-245$ & 1.10E-02 & 4.07E-04 & Yes \\
\hline $\mathrm{Cm}-246$ & 1.42E-02 & $5.23 \mathrm{E}-04$ & Yes \\
\hline $\mathrm{Cm}-247$ & $2.65 \mathrm{E}-02$ & $9.77 \mathrm{E}-04$ & Yes \\
\hline $\mathrm{Cm}-248$ & $2.76 \mathrm{E}-02$ & 1.02E-03 & Yes \\
\hline Co-60 & 1.74E-52 & $6.41 \mathrm{E}-54$ & \\
\hline Cs-135 & 1.34E-03 & $4.94 \mathrm{E}-05$ & \\
\hline Cs-137 & 2.33E-07 & $8.59 \mathrm{E}-09$ & \\
\hline Eu-154 & 5.75E-31 & $2.12 \mathrm{E}-32$ & \\
\hline Eu-155 & $1.25 E-55$ & $4.62 \mathrm{E}-57$ & \\
\hline Fr-221 & 1.29E-03 & 4.75E-05 & \\
\hline Fr-223 & 1.87E-07 & $6.88 \mathrm{E}-09$ & \\
\hline I-129 & 4.35E-04 & 1.60E-05 & \\
\hline $\mathrm{Nb}-93 \mathrm{~m}$ & 4.43E-02 & $1.63 \mathrm{E}-03$ & Yes \\
\hline $\mathrm{Ni}-59$ & 6.57E-01 & $2.42 \mathrm{E}-02$ & Yes \\
\hline $\mathrm{Ni}-63$ & 7.58E-02 & $2.79 \mathrm{E}-03$ & Yes \\
\hline Np-237 & 3.61E-02 & 1.33E-03 & Yes \\
\hline Np-238 & 6.70E-06 & 2.47E-07 & \\
\hline Np-239 & $1.43 E+00$ & $5.25 \mathrm{E}-02$ & \\
\hline $\mathrm{Np}-240 \mathrm{~m}$ & 1.94E-07 & 7.14E-09 & \\
\hline Pa-231 & 1.40E-05 & 5.17E-07 & \\
\hline $\mathrm{Pa}-233$ & 3.61E-02 & $1.33 \mathrm{E}-03$ & \\
\hline $\mathrm{Pa}-234$ & 7.45E-05 & $2.75 \mathrm{E}-06$ & \\
\hline $\mathrm{Pa}-234 \mathrm{~m}$ & 2.26E-02 & 8.31E-04 & \\
\hline Pb-209 & 1.29E-03 & 4.75E-05 & \\
\hline $\mathrm{Pb}-210$ & 4.96E-05 & $1.83 \mathrm{E}-06$ & \\
\hline $\mathrm{Pb}-211$ & 1.35E-05 & 4.99E-07 & \\
\hline $\mathrm{Pb}-212$ & 3.01E-05 & 1.11E-06 & \\
\hline $\mathrm{Pb}-214$ & 5.31E-05 & $1.96 \mathrm{E}-06$ & \\
\hline Pd-107 & 6.89E-04 & $2.54 \mathrm{E}-05$ & \\
\hline Pm-147 & 4.58E-102 & $1.69 \mathrm{E}-103$ & \\
\hline Po-210 & 4.95E-05 & 1.83E-06 & \\
\hline Po-211 & 3.79E-08 & 1.40E-09 & \\
\hline Po-212 & 1.93E-05 & 7.11E-07 & \\
\hline Po-213 & 1.26E-03 & 4.64E-05 & \\
\hline Po-214 & 5.31E-05 & 1.96E-06 & \\
\hline Po-215 & 1.35E-05 & 4.99E-07 & \\
\hline Po-216 & 3.01E-05 & $1.11 \mathrm{E}-06$ & \\
\hline
\end{tabular}

\begin{tabular}{|c|c|c|c|}
\hline Nuclide & $\begin{array}{l}\text { Y } 2915 \\
\mu \mathrm{Ci} / \mathrm{g}\end{array}$ & $\begin{array}{c}\text { Fraction of } \\
\text { Activity }\end{array}$ & Reportable \\
\hline Po-218 & 5.31E-05 & $1.96 \mathrm{E}-06$ & \\
\hline Pu-238 & 2.22E-02 & $8.18 \mathrm{E}-04$ & Yes \\
\hline Pu-239 & $1.34 \mathrm{E}+01$ & 4.93E-01 & Yes \\
\hline Pu-240 & $4.54 \mathrm{E}+00$ & 1.67E-01 & Yes \\
\hline Pu-241 & 1.11E-02 & $4.08 \mathrm{E}-04$ & Yes \\
\hline Pu-242 & $5.48 \mathrm{E}-03$ & 2.02E-04 & Yes \\
\hline Pu-243 & $2.65 \mathrm{E}-02$ & $9.77 \mathrm{E}-04$ & \\
\hline Pu-244 & 1.94E-07 & 7.15E-09 & \\
\hline Ra-223 & 1.35E-05 & 4.99E-07 & \\
\hline Ra-224 & 3.01E-05 & 1.11E-06 & \\
\hline Ra-225 & 1.29E-03 & $4.75 \mathrm{E}-05$ & \\
\hline Ra-226 & 5.31E-05 & $1.96 \mathrm{E}-06$ & \\
\hline Ra-228 & 3.01E-05 & 1.11E-06 & \\
\hline Rn-219 & 1.35E-05 & $4.99 \mathrm{E}-07$ & \\
\hline Rn-220 & 3.01E-05 & 1.11E-06 & \\
\hline Rn-222 & 5.31E-05 & 1.96E-06 & \\
\hline Sb-125 & 1.06E-100 & $3.92 \mathrm{E}-102$ & \\
\hline Sb-126 & $1.98 \mathrm{E}-03$ & $7.28 \mathrm{E}-05$ & \\
\hline Sb-126m & 1.41E-02 & $5.20 \mathrm{E}-04$ & \\
\hline Se-79 & 1.95E-02 & 7.19E-04 & Yes \\
\hline Sm-147 & 2.97E-08 & 1.09E-09 & \\
\hline Sm-151 & 1.77E-01 & $6.53 \mathrm{E}-03$ & Yes \\
\hline Sn-121 & 1.90E-05 & $7.00 \mathrm{E}-07$ & \\
\hline $\mathrm{Sn}-121 \mathrm{~m}$ & $2.45 \mathrm{E}-05$ & $9.02 \mathrm{E}-07$ & \\
\hline Sn-126 & 1.41E-02 & $5.20 \mathrm{E}-04$ & Yes \\
\hline Sr-90 & 1.90E-06 & $7.00 \mathrm{E}-08$ & \\
\hline TC-99 & 1.95E-01 & $7.20 \mathrm{E}-03$ & Yes \\
\hline Te-125m & 2.57E-101 & $9.47 \mathrm{E}-103$ & \\
\hline Th-227 & 1.33E-05 & 4.92E-07 & \\
\hline Th-228 & 3.01E-05 & 1.11E-06 & \\
\hline Th-229 & 1.29E-03 & 4.75E-05 & \\
\hline Th-230 & 3.13E-04 & 1.15E-05 & \\
\hline Th-231 & 7.41E-04 & $2.73 \mathrm{E}-05$ & \\
\hline Th-232 & $3.01 \mathrm{E}-05$ & $1.11 \mathrm{E}-06$ & \\
\hline Th-234 & 2.26E-02 & 8.33E-04 & \\
\hline TI-207 & 1.35E-05 & 4.97E-07 & \\
\hline TI-208 & 1.08E-05 & 3.99E-07 & \\
\hline TI-209 & $2.78 \mathrm{E}-05$ & 1.03E-06 & \\
\hline U-233 & 1.57E-02 & $5.78 \mathrm{E}-04$ & Yes \\
\hline U-234 & 3.96E-02 & $1.46 \mathrm{E}-03$ & Yes \\
\hline U-235 & 7.41E-04 & $2.73 E-05$ & \\
\hline U-236 & $9.74 \mathrm{E}-04$ & 3.59E-05 & \\
\hline U-237 & 2.71E-07 & 9.99E-09 & \\
\hline U-238 & $2.26 \mathrm{E}-02$ & 8.33E-04 & Yes \\
\hline U-240 & 1.94E-07 & 7.14E-09 & \\
\hline Y-90 & $1.90 \mathrm{E}-06$ & $7.00 \mathrm{E}-08$ & \\
\hline Zr-93 & 4.43E-02 & 1.63E-03 & Yes \\
\hline TOTAL & $2.71 \mathrm{E}+01$ & $1.00 \mathrm{E}+00$ & \\
\hline
\end{tabular}


WSRC-TR-2005-00157

Revision 0

APPENDIX K. ACTIVITIES OF DRIED SLUDGE IN YEAR $3015(\mu \mathrm{Ci} / \mathrm{g})$ 
WSRC-TR-2005-00157

Revision 0

\begin{tabular}{|c|c|c|c|}
\hline Nuclide & $\begin{array}{l}\text { Y 3015 } \\
\mu \mathrm{Ci} / \mathrm{g}\end{array}$ & $\begin{array}{c}\text { Fraction of } \\
\text { Activity }\end{array}$ & Reportable \\
\hline Ac-225 & 1.42E-03 & 5.44E-05 & \\
\hline Ac-227 & 1.51E-05 & $5.76 \mathrm{E}-07$ & \\
\hline Ac-228 & 3.01E-05 & 1.15E-06 & \\
\hline Am-241 & $4.04 \mathrm{E}+00$ & $1.54 \mathrm{E}-01$ & Yes \\
\hline Am-242 & 8.88E-04 & $3.39 \mathrm{E}-05$ & \\
\hline Am-242m & 8.93E-04 & $3.41 \mathrm{E}-05$ & \\
\hline Am-243 & $1.41 \mathrm{E}+00$ & $5.40 \mathrm{E}-02$ & Yes \\
\hline At-217 & 1.42E-03 & $5.44 \mathrm{E}-05$ & \\
\hline At-218 & 1.30E-08 & $4.96 \mathrm{E}-10$ & \\
\hline $\mathrm{Ba}-137 \mathrm{~m}$ & 2.19E-08 & 8.35E-10 & \\
\hline Bi-210 & $6.10 \mathrm{E}-05$ & 2.33E-06 & \\
\hline $\mathrm{Bi}-211$ & 1.51E-05 & $5.76 \mathrm{E}-07$ & \\
\hline $\mathrm{Bi}-212$ & 3.01E-05 & 1.15E-06 & \\
\hline $\mathrm{Bi}-213$ & 1.42E-03 & $5.44 \mathrm{E}-05$ & \\
\hline $\mathrm{Bi}-214$ & $6.49 \mathrm{E}-05$ & $2.48 \mathrm{E}-06$ & \\
\hline Cf-249 & 3.84E-03 & $1.47 \mathrm{E}-04$ & Yes \\
\hline Cf-250 & $4.25 \mathrm{E}-26$ & 1.62E-27 & \\
\hline Cf-251 & 1.03E-02 & $3.92 \mathrm{E}-04$ & Yes \\
\hline $\mathrm{Cm}-242$ & 7.37E-04 & $2.81 \mathrm{E}-05$ & \\
\hline $\mathrm{Cm}-243$ & $5.48 \mathrm{E}-12$ & $2.09 \mathrm{E}-13$ & \\
\hline $\mathrm{Cm}-244$ & 1.14E-15 & $4.36 \mathrm{E}-17$ & \\
\hline $\mathrm{Cm}-245$ & 1.10E-02 & $4.20 \mathrm{E}-04$ & Yes \\
\hline $\mathrm{Cm}-246$ & 1.40E-02 & $5.34 \mathrm{E}-04$ & Yes \\
\hline $\mathrm{Cm}-247$ & $2.65 \mathrm{E}-02$ & $1.01 \mathrm{E}-03$ & Yes \\
\hline $\mathrm{Cm}-248$ & $2.76 \mathrm{E}-02$ & $1.06 \mathrm{E}-03$ & Yes \\
\hline Co-60 & 3.38E-58 & 1.29E-59 & \\
\hline Cs-135 & 1.34E-03 & $5.12 \mathrm{E}-05$ & \\
\hline Cs-137 & 2.31E-08 & $8.83 \mathrm{E}-10$ & \\
\hline Eu-154 & $2.18 \mathrm{E}-34$ & $8.34 \mathrm{E}-36$ & \\
\hline Eu-155 & 1.07E-61 & $4.09 \mathrm{E}-63$ & \\
\hline Fr-221 & 1.42E-03 & 5.44E-05 & \\
\hline Fr-223 & 2.08E-07 & 7.95E-09 & \\
\hline I-129 & 4.35E-04 & 1.66E-05 & \\
\hline $\mathrm{Nb}-93 \mathrm{~m}$ & 4.43E-02 & $1.69 \mathrm{E}-03$ & Yes \\
\hline $\mathrm{Ni}-59$ & 6.57E-01 & $2.51 \mathrm{E}-02$ & Yes \\
\hline $\mathrm{Ni}-63$ & 3.68E-02 & 1.41E-03 & Yes \\
\hline Np-237 & 3.63E-02 & $1.39 \mathrm{E}-03$ & Yes \\
\hline Np-238 & 4.25E-06 & $1.62 \mathrm{E}-07$ & \\
\hline Np-239 & $1.41 \mathrm{E}+00$ & $5.40 \mathrm{E}-02$ & \\
\hline $\mathrm{Np}-240 \mathrm{~m}$ & 2.15E-07 & 8.21E-09 & \\
\hline Pa-231 & 1.56E-05 & $5.94 \mathrm{E}-07$ & \\
\hline $\mathrm{Pa}-233$ & 3.63E-02 & $1.39 \mathrm{E}-03$ & \\
\hline $\mathrm{Pa}-234$ & 7.45E-05 & 2.85E-06 & \\
\hline $\mathrm{Pa}-234 \mathrm{~m}$ & 2.26E-02 & 8.62E-04 & \\
\hline Pb-209 & 1.42E-03 & $5.44 \mathrm{E}-05$ & \\
\hline $\mathrm{Pb}-210$ & $6.10 \mathrm{E}-05$ & $2.33 E-06$ & \\
\hline $\mathrm{Pb}-211$ & 1.51E-05 & 5.76E-07 & \\
\hline $\mathrm{Pb}-212$ & 3.01E-05 & 1.15E-06 & \\
\hline $\mathrm{Pb}-214$ & $6.49 \mathrm{E}-05$ & $2.48 \mathrm{E}-06$ & \\
\hline Pd-107 & 6.89E-04 & $2.63 E-05$ & \\
\hline Pm-147 & $1.54 \mathrm{E}-113$ & $5.87 \mathrm{E}-115$ & \\
\hline Po-210 & $6.10 \mathrm{E}-05$ & 2.33E-06 & \\
\hline Po-211 & 4.22E-08 & 1.61E-09 & \\
\hline Po-212 & 1.93E-05 & 7.37E-07 & \\
\hline Po-213 & 1.39E-03 & 5.32E-05 & \\
\hline Po-214 & 6.49E-05 & $2.48 \mathrm{E}-06$ & \\
\hline Po-215 & 1.51E-05 & $5.76 \mathrm{E}-07$ & \\
\hline Po-216 & 3.01E-05 & 1.15E-06 & \\
\hline
\end{tabular}

\begin{tabular}{|c|c|c|c|}
\hline Nuclide & $\begin{array}{l}\text { Y } 3015 \\
\mu \mathrm{Ci} / \mathrm{g}\end{array}$ & $\begin{array}{c}\text { Fraction of } \\
\text { Activity }\end{array}$ & Reportable \\
\hline Po-218 & $6.49 \mathrm{E}-05$ & $2.48 \mathrm{E}-06$ & \\
\hline Pu-238 & 1.06E-02 & 4.04E-04 & Yes \\
\hline Pu-239 & $1.34 \mathrm{E}+01$ & 5.10E-01 & Yes \\
\hline Pu-240 & $4.49 \mathrm{E}+00$ & 1.71E-01 & Yes \\
\hline Pu-241 & 1.10E-02 & $4.20 \mathrm{E}-04$ & Yes \\
\hline Pu-242 & $5.48 \mathrm{E}-03$ & 2.10E-04 & Yes \\
\hline Pu-243 & $2.65 \mathrm{E}-02$ & 1.01E-03 & \\
\hline Pu-244 & 2.15E-07 & 8.22E-09 & \\
\hline Ra-223 & 1.51E-05 & 5.76E-07 & \\
\hline Ra-224 & 3.01E-05 & 1.15E-06 & \\
\hline Ra-225 & 1.42E-03 & 5.44E-05 & \\
\hline Ra-226 & 6.49E-05 & $2.48 \mathrm{E}-06$ & \\
\hline Ra-228 & 3.01E-05 & 1.15E-06 & \\
\hline Rn-219 & 1.51E-05 & 5.76E-07 & \\
\hline Rn-220 & 3.01E-05 & 1.15E-06 & \\
\hline Rn-222 & $6.49 \mathrm{E}-05$ & $2.48 \mathrm{E}-06$ & \\
\hline Sb-125 & 1.44E-111 & $5.51 \mathrm{E}-113$ & \\
\hline Sb-126 & 1.97E-03 & 7.54E-05 & \\
\hline Sb-126m & 1.41E-02 & 5.39E-04 & \\
\hline Se-79 & 1.95E-02 & 7.45E-04 & Yes \\
\hline Sm-147 & 2.97E-08 & 1.13E-09 & \\
\hline Sm-151 & 8.21E-02 & $3.14 \mathrm{E}-03$ & Yes \\
\hline Sn-121 & 5.39E-06 & 2.06E-07 & \\
\hline $\mathrm{Sn}-121 \mathrm{~m}$ & $6.94 \mathrm{E}-06$ & $2.65 \mathrm{E}-07$ & \\
\hline Sn-126 & 1.41E-02 & 5.39E-04 & Yes \\
\hline Sr-90 & 1.76E-07 & 6.72E-09 & \\
\hline TC-99 & 1.95E-01 & 7.46E-03 & Yes \\
\hline Te-125m & 3.49E-112 & 1.33E-113 & \\
\hline Th-227 & 1.49E-05 & 5.68E-07 & \\
\hline Th-228 & 3.01E-05 & 1.15E-06 & \\
\hline Th-229 & 1.42E-03 & 5.44E-05 & \\
\hline Th-230 & 3.48E-04 & 1.33E-05 & \\
\hline Th-231 & 7.42E-04 & 2.84E-05 & \\
\hline Th-232 & $3.01 \mathrm{E}-05$ & 1.15E-06 & \\
\hline Th-234 & 2.26E-02 & 8.63E-04 & \\
\hline TI-207 & 1.50E-05 & 5.74E-07 & \\
\hline TI-208 & 1.08E-05 & 4.13E-07 & \\
\hline TI-209 & 3.07E-05 & 1.17E-06 & \\
\hline U-233 & 1.57E-02 & 5.99E-04 & Yes \\
\hline U-234 & 3.96E-02 & $1.51 \mathrm{E}-03$ & Yes \\
\hline U-235 & 7.42E-04 & 2.84E-05 & \\
\hline U-236 & $9.87 \mathrm{E}-04$ & 3.77E-05 & \\
\hline U-237 & 2.70E-07 & 1.03E-08 & \\
\hline U-238 & $2.26 \mathrm{E}-02$ & 8.63E-04 & Yes \\
\hline U-240 & 2.15E-07 & 8.21E-09 & \\
\hline Y-90 & $1.76 \mathrm{E}-07$ & 6.72E-09 & \\
\hline Zr-93 & 4.43E-02 & 1.69E-03 & Yes \\
\hline TOTAL & $2.62 \mathrm{E}+01$ & $1.00 \mathrm{E}+00$ & \\
\hline
\end{tabular}


WSRC-TR-2005-00157

Revision 0

\section{APPENDIX L. ACTIVITIES OF DRIED SLUDGE IN YEAR $3115(\mu \mathrm{Ci} / \mathrm{g})$}


WSRC-TR-2005-00157

Revision 0

\begin{tabular}{|c|c|c|c|}
\hline Nuclide & $\begin{array}{c}3115 \\
\mu \mathrm{Ci} / \mathrm{g}\end{array}$ & $\begin{array}{c}\text { Fraction of } \\
\text { Activity }\end{array}$ & Reportable \\
\hline Ac-225 & 1.56E-03 & 6.13E-05 & \\
\hline Ac-227 & 1.66E-05 & 6.54E-07 & \\
\hline Ac-228 & 3.01E-05 & 1.19E-06 & \\
\hline Am-241 & $3.44 \mathrm{E}+00$ & 1.36E-01 & Yes \\
\hline Am-242 & 5.63E-04 & 2.22E-05 & \\
\hline$A m-242 m$ & 5.66E-04 & 2.23E-05 & \\
\hline Am-243 & $1.40 \mathrm{E}+00$ & 5.51E-02 & Yes \\
\hline At-217 & 1.56E-03 & 6.13E-05 & \\
\hline At-218 & 1.55E-08 & $6.11 \mathrm{E}-10$ & \\
\hline Ba-137m & 2.17E-09 & 8.54E-11 & \\
\hline Bi-210 & 7.35E-05 & 2.89E-06 & \\
\hline Bi-211 & 1.66E-05 & 6.54E-07 & \\
\hline Bi-212 & 3.01E-05 & 1.19E-06 & \\
\hline Bi-213 & 1.56E-03 & 6.13E-05 & \\
\hline $\mathrm{Bi}-214$ & 7.76E-05 & 3.06E-06 & \\
\hline Cf-249 & 3.15E-03 & $1.24 \mathrm{E}-04$ & Yes \\
\hline Cf-250 & $2.12 \mathrm{E}-28$ & 8.36E-30 & \\
\hline Cf-251 & 9.51E-03 & 3.74E-04 & Yes \\
\hline Cm-242 & 4.67E-04 & 1.84E-05 & \\
\hline $\mathrm{Cm}-243$ & 4.81E-13 & 1.90E-14 & \\
\hline $\mathrm{Cm}-244$ & $2.48 \mathrm{E}-17$ & 9.77E-19 & \\
\hline $\mathrm{Cm}-245$ & 1.09E-02 & 4.30E-04 & Yes \\
\hline Cm-246 & 1.38E-02 & 5.43E-04 & Yes \\
\hline $\mathrm{Cm}-247$ & 2.65E-02 & 1.04E-03 & Yes \\
\hline $\mathrm{Cm}-248$ & 2.76E-02 & 1.09E-03 & Yes \\
\hline Co-60 & $6.58 E-64$ & $2.59 E-65$ & \\
\hline Cs-135 & 1.34E-03 & 5.27E-05 & \\
\hline Cs-137 & 2.29E-09 & 9.03E-11 & \\
\hline Eu-154 & 8.28E-38 & 3.26E-39 & \\
\hline Eu-155 & 9.13E-68 & 3.59E-69 & \\
\hline Fr-221 & 1.56E-03 & 6.13E-05 & \\
\hline Fr-223 & 2.29E-07 & 9.03E-09 & \\
\hline $\mathrm{I}-129$ & 4.35E-04 & 1.71E-05 & \\
\hline Nb-93m & 4.43E-02 & 1.74E-03 & Yes \\
\hline $\mathrm{Ni}-59$ & 6.56E-01 & 2.58E-02 & Yes \\
\hline $\mathrm{Ni}-63$ & 1.79E-02 & 7.04E-04 & Yes \\
\hline Np-237 & 3.64E-02 & 1.43E-03 & Yes \\
\hline Np-238 & 2.69E-06 & 1.06E-07 & \\
\hline Np-239 & $1.40 \mathrm{E}+00$ & 5.51E-02 & \\
\hline $\mathrm{Np}-240 \mathrm{~m}$ & 2.36E-07 & 9.30E-09 & \\
\hline $\mathrm{Pa}-231$ & 1.71E-05 & 6.73E-07 & \\
\hline $\mathrm{Pa}-233$ & 3.64E-02 & 1.43E-03 & \\
\hline Pa-234 & 7.45E-05 & 2.93E-06 & \\
\hline $\mathrm{Pa}-234 \mathrm{~m}$ & 2.26E-02 & 8.88E-04 & \\
\hline Pb-209 & 1.56E-03 & 6.13E-05 & \\
\hline $\mathrm{Pb}-210$ & 7.35E-05 & 2.89E-06 & \\
\hline $\mathrm{Pb}-211$ & 1.66E-05 & 6.54E-07 & \\
\hline $\mathrm{Pb}-212$ & 3.01E-05 & 1.19E-06 & \\
\hline $\mathrm{Pb}-214$ & 7.76E-05 & 3.06E-06 & \\
\hline Pd-107 & 6.89E-04 & 2.71E-05 & \\
\hline Pm-147 & 5.15E-125 & 2.03E-126 & \\
\hline Po-210 & 7.34E-05 & 2.89E-06 & \\
\hline Po-211 & 4.65E-08 & 1.83E-09 & \\
\hline Po-212 & 1.93E-05 & 7.59E-07 & \\
\hline Po-213 & $1.52 \mathrm{E}-03$ & 6.00E-05 & \\
\hline Po-214 & 7.76E-05 & 3.06E-06 & \\
\hline Po-215 & 1.66E-05 & $6.54 \mathrm{E}-07$ & \\
\hline
\end{tabular}

\begin{tabular}{|c|c|c|c|}
\hline Nuclide & $\begin{array}{c}3115 \\
\mu \mathrm{Ci} / \mathrm{g}\end{array}$ & $\begin{array}{c}\text { Fraction of } \\
\text { Activity }\end{array}$ & Reportable \\
\hline Po-216 & 3.01E-05 & 1.19E-06 & \\
\hline Po-218 & 7.76E-05 & 3.06E-06 & \\
\hline Pu-238 & $5.11 \mathrm{E}-03$ & 2.01E-04 & Yes \\
\hline Pu-239 & $1.33 E+01$ & 5.24E-01 & Yes \\
\hline Pu-240 & $4.44 \mathrm{E}+00$ & $1.75 \mathrm{E}-01$ & Yes \\
\hline Pu-241 & 1.09E-02 & 4.31E-04 & Yes \\
\hline Pu-242 & $5.49 E-03$ & 2.16E-04 & Yes \\
\hline Pu-243 & $2.65 \mathrm{E}-02$ & $1.04 \mathrm{E}-03$ & \\
\hline Pu-244 & 2.36E-07 & 9.31E-09 & \\
\hline Ra-223 & 1.66E-05 & 6.54E-07 & \\
\hline Ra-224 & 3.01E-05 & $1.19 E-06$ & \\
\hline Ra-225 & $1.56 \mathrm{E}-03$ & $6.13 E-05$ & \\
\hline Ra-226 & 7.76E-05 & 3.06E-06 & \\
\hline Ra-228 & 3.01E-05 & $1.19 \mathrm{E}-06$ & \\
\hline Rn-219 & $1.66 \mathrm{E}-05$ & $6.54 \mathrm{E}-07$ & \\
\hline Rn-220 & 3.01E-05 & $1.19 E-06$ & \\
\hline $\mathrm{Rn}-222$ & 7.76E-05 & 3.06E-06 & \\
\hline Sb-125 & 1.96E-122 & 7.71E-124 & \\
\hline Sb-126 & $1.97 \mathrm{E}-03$ & 7.77E-05 & \\
\hline Sb-126m & $1.41 \mathrm{E}-02$ & 5.55E-04 & \\
\hline Se-79 & $1.95 \mathrm{E}-02$ & $7.66 \mathrm{E}-04$ & Yes \\
\hline Sm-147 & 2.97E-08 & 1.17E-09 & \\
\hline Sm-151 & 3.80E-02 & $1.50 \mathrm{E}-03$ & Yes \\
\hline Sn-121 & $1.53 \mathrm{E}-06$ & $6.01 E-08$ & \\
\hline Sn-121m & $1.97 \mathrm{E}-06$ & $7.75 \mathrm{E}-08$ & \\
\hline Sn-126 & $1.41 \mathrm{E}-02$ & $5.55 \mathrm{E}-04$ & Yes \\
\hline Sr-90 & $1.63 \mathrm{E}-08$ & $6.40 \mathrm{E}-10$ & \\
\hline Tc-99 & $1.95 \mathrm{E}-01$ & 7.69E-03 & Yes \\
\hline Te-125m & 4.74E-123 & 1.87E-124 & \\
\hline Th-227 & 1.64E-05 & $6.45 \mathrm{E}-07$ & \\
\hline Th-228 & 3.01E-05 & 1.19E-06 & \\
\hline Th-229 & $1.56 \mathrm{E}-03$ & $6.13 \mathrm{E}-05$ & \\
\hline Th-230 & 3.83E-04 & 1.51E-05 & \\
\hline Th-231 & 7.44E-04 & 2.93E-05 & \\
\hline Th-232 & 3.01E-05 & $1.19 \mathrm{E}-06$ & \\
\hline Th-234 & $2.26 \mathrm{E}-02$ & 8.90E-04 & \\
\hline Tl-207 & $1.66 \mathrm{E}-05$ & $6.52 \mathrm{E}-07$ & \\
\hline TI-208 & $1.08 \mathrm{E}-05$ & $4.26 \mathrm{E}-07$ & \\
\hline TI-209 & 3.36E-05 & $1.32 \mathrm{E}-06$ & \\
\hline U-233 & $1.57 \mathrm{E}-02$ & $6.18 \mathrm{E}-04$ & Yes \\
\hline U-234 & $3.96 \mathrm{E}-02$ & $1.56 \mathrm{E}-03$ & Yes \\
\hline U-235 & $7.44 \mathrm{E}-04$ & 2.93E-05 & \\
\hline U-236 & $1.00 \mathrm{E}-03$ & 3.94E-05 & \\
\hline $\mathrm{U}-237$ & 2.68E-07 & 1.06E-08 & \\
\hline $\mathrm{U}-238$ & $2.26 \mathrm{E}-02$ & $8.90 \mathrm{E}-04$ & Yes \\
\hline U-240 & $2.36 \mathrm{E}-07$ & 9.30E-09 & \\
\hline$Y-90$ & $1.63 \mathrm{E}-08$ & $6.41 \mathrm{E}-10$ & \\
\hline Zr-93 & 4.43E-02 & $1.74 \mathrm{E}-03$ & Yes \\
\hline TOTAL & $2.54 \mathrm{E}+01$ & $1.00 \mathrm{E}+00$ & \\
\hline
\end{tabular}


WSRC-TR-2005-00157

Revision 0

This page intentionally left blank. 
Distribution:

E. W. Holtzscheiter, 773-A

D. A. Crowley, 999-W

S. L. Marra, 999-W

T. B. Calloway, 999-W

N. E. Bibler, 773-A

C.M. Jantzen, 773-A

J. R. Harbour, 773-42A

R. A. Sigg, 773-41A

G. C. Wicks, 773-A

C. C. DiPrete, 773-A

D. P. DiPrete, 773-A

C. C. Herman, 773-42A

T. L. Fellinger, 773-A

M. E. Stone, 999-W

D. K. Peeler, 999-W

M. S. Miller, 704-S

J. E. Occhipinti, 704-S

R. M. Hoeppel, 704-27S

J. F. Iaukea, 704-30S

J. W. Ray, 704-S

F. A. Washburn, 704-28S

A. V. Staub, 704-27S

B. H. Culbertson, 704-27S

A. B. Sanders, 704-27S

W. B. Van-Pelt, 704-S

O. G. Lien, 704-28S

H. H. Elder, 766-H

J. M. Gillam, 766-H

P. J. Hill, 766-H

D. C. Bumgardner, 766-H 